Florida International University FIU Digital Commons

$3-22-2012$

\title{
Assessing the Impact of Business Group Diversification on the Internationalization of their Affiliates: The Case of Latin American Firms
}

Armando J. Borda

Florida International University, abord001@fiu.edu

DOI: $10.25148 /$ etd.FI12050250

Follow this and additional works at: https://digitalcommons.fiu.edu/etd

\section{Recommended Citation}

Borda, Armando J., "Assessing the Impact of Business Group Diversification on the Internationalization of their Affiliates: The Case of Latin American Firms" (2012). FIU Electronic Theses and Dissertations. 644.

https://digitalcommons.fiu.edu/etd/644 


\section{FLORIDA INTERNATIONAL UNIVERSITY}

Miami, Florida

ASSESSING THE IMPACT OF BUSINESS GROUP DIVERSIFICATION ON THE INTERNATIONALIZATION OF THEIR AFFILIATES: THE CASE OF LATIN AMERICAN FIRMS

A dissertation submitted in partial fulfillment of the requirements for the degree of DOCTOR OF PHILOSOPHY

in BUSINESS ADMINISTRATION

by

Armando Borda 
To: Dean Joyce Elam

College of Business Administration

This dissertation, written by Armando Borda, and entitled Assessing the Impact of Business Group Diversification on the Internationalization of Their Affiliates: The case of Latin American firms, having been approved in respect to style and intellectual content, is referred to you for judgment.

We have read this dissertation and recommend that it be approved.

$\begin{array}{r}\hline \text { Aya Chacar } \\ \hline \text { Sumit Kundu } \\ \hline \text { John Mezias } \\ \hline \text { Paulette Johnson } \\ \hline \text { William Newburry, Major Professor }\end{array}$

Date of Defense: March 22, 2012

The dissertation of Armando Borda is approved.

$\begin{array}{r}\text { Dean Joyce Elam } \\ \text { College of Business Administration } \\ \hline \begin{array}{r}\text { Dean Lakshmi N. Reddi } \\ \text { University Graduate School }\end{array}\end{array}$

Florida International University, 2012 
(C) Copyright 2012 by Armando Borda All rights reserved. 


\section{DEDICATION}

First of all, I would like to dedicate this thesis to my wife. Without her support during this entire journey, the conclusion of this dissertation would be impossible: Thanks Fiory for being so great: you are my soul mate!

I further dedicate my work in this dissertation to my parents and brothers. Their constant guidance and encouragement have helped me to overcome all the difficulties that I found during these challenging years. Also, I am very grateful to Mariella and Stanley Wakshlag. Both of you have been an excellent support during my whole stance in the States. You received me at your place and treat me as one of your offspring when I needed the most.

I also would to say thank you to my mother in law. She brought balance to our lives specially when my two beautiful children born. All your wise advices have aided us to consolidate our family in conditions of uncertainty. Likewise, I want to say thank you to Luciana and Armando, you bring the extra motivation that I needed during the last years of the program. It was (and still is) amazing to see your faces when I arrive home: you guys pay my day-off. I love you so much!

Finally, I dedicate this dissertation to Carlos Tejada Oshiro. If it wasn't for Professor Tejada encouragement, I would have never traveled to the States to pursue this degree. Professor, I can't tell you personally how grateful I am, but I want to use these few lines to tell you that you have made the difference for me: you actually changed my life. 


\section{ACKNOWLEDGMENTS}

First of all, I would like to recognize the constant guidance provided by all the members of my committee chaired by Professor William Newburry and including Professors Aya Chacar, Sumit Kundu, John Mezias and Paulette Johnson. Specially, I am extremely grateful for the support of Professor William Newburry. Dr. Newburry, thanks for believing in me, for guiding me during this whole process, for pushing me to be a better researcher and instructor and for being more than a mentor, for being my friend.

I thank to Professor Galen Kroeck and all members of the department of Management and International Business at Florida International University for giving me the opportunity to participate in the Ph.D. Program. I have found the coursework throughout the Program to be stimulating and thoughtful.

I further wish to acknowledge the Graduate School for providing me financial support through the Doctoral Evidence Acquisition Fellowship in fall 2010. Further, I would like to recognize the funding for conference travel provided by the Dean office of the College of Business, The Center for International Education Research (CIBER) at FIU, the Graduate and Professional Student Committee (GPSS) and the Department of Management and International Business. Moreover, I would like to recognize Universidad ESAN and in particular Professors Jorge Talavera, Jaime Serida and Sergio Bravo for supporting me during my doctoral studies at Florida International University.

Finally, I am also grateful to the Ph.D. students with whom we form a family. Abdul, Abrahim, Chen-Kuo Pai, Gladys, Santosh, Sokol and Elda, Wei and Michelle, Watcharaphong "Kenny" and Yu-Kai "Mike" thanks for contributing to this learning experience. You made this endeavor unforgettable. 
ABSTRACT OF THE DISSERTATION

ASSESSING THE IMPACT OF BUSINESS GROUP DIVERSIFICATION ON THE INTERNATIONALIZATION OF THEIR AFFILIATES: THE CASE OF LATIN AMERICAN FIRMS

by

Armando Borda

Florida International University, 2012

Miami, Florida

Professor William Newburry, Major Professor

This dissertation explored the capacity of business group diversification to generate value to their affiliates in an institutional environment characterized by the adoption of structural promarket reforms. In particular, the three empirical essays explored the impact of business group diversification on the internationalization process of their affiliates.

The first essay examined the direct effect of business group diversification on firm performance and its moderating effect on the multinationality-performance relationship. It further explored whether such moderating effect varies depending upon whether the focal affiliate is a manufacturing or service firm. The findings suggested that the benefits of business group diversification on firm performance have a threshold, that those benefits are significant at earlier stages of internationalization and that these benefits are stronger for service firms.

The second essay studied the capacity of business group diversification to ameliorate the negative effects of the added complexity faced by its affiliates when they internationalized. The essay explored this capacity in different dimensions of international complexity. The results indicated that business group diversification effectively ameliorated the effects of the added 
international complexity. This positive effect is stronger in the institutional voids rather than the societal complexity dimension. In the former dimension, diversified business groups can use both their non-market resources and previous experience to ameliorate the effects of complexity on firm performance.

The last essay explored whether the benefits of business group diversification on the scope-performance relationship varies depending on the level of development of the network of subsidiaries and the region of operation of the focal firm. The results suggested that the benefits of business group diversification are location bound within the region but that they are not related to the level of development of the targeted countries.

The three essays use longitudinal analyses on a sample of Latin American firms to test the hypotheses. While the first essay used multilevel models and fix effects models, the last two essays used exclusively fix effects models to assess the impact of business group diversification. In conclusion, this dissertation aimed to explain the capacity of business group diversification to generate value under conditions of institutional change. 


\section{TABLE OF CONTENTS}

CHAPTER

PAGE

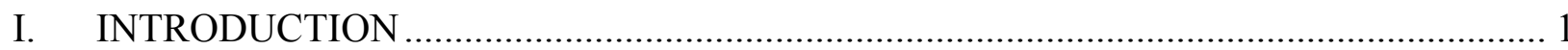

II. FIRM INTERNATIONALIZATION, BUSINESS GROUP DIVERSIFICATION AND FIRM PERFORMANCE: THE CASE OF LATIN AMERICAN FIRMS ..................................... 6

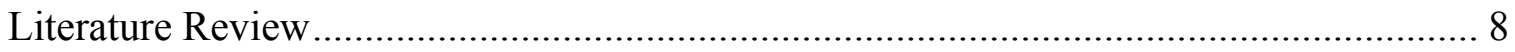

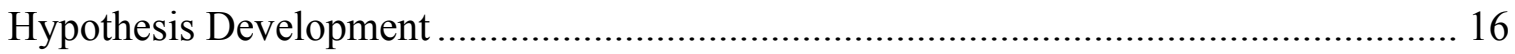

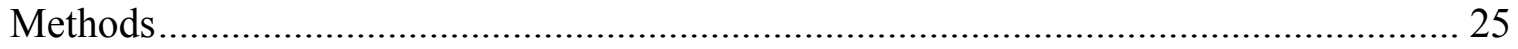

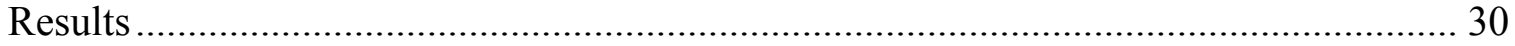

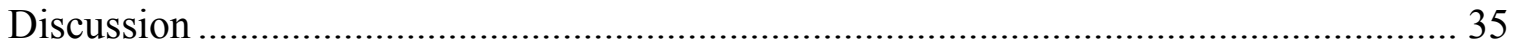

Limitations and Directions for Future Research ………............................................ 39

III. MANAGING THE COMPLEXITIES OF INTERNATIONALIZATION: ASSESSING THE IMPACT OF BUSINESS GROUP DIVERSIFICATION. EVIDENCE FROM LATIN

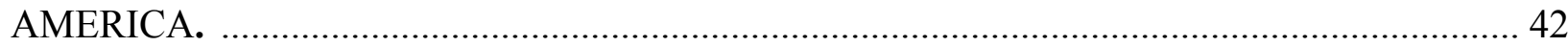

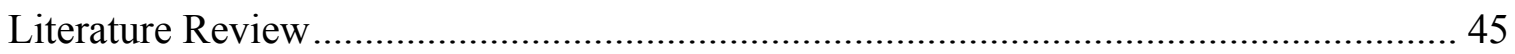

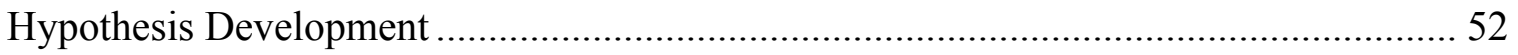

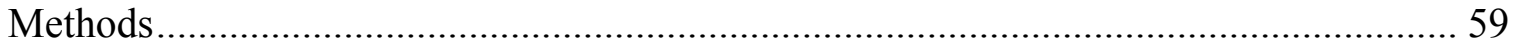

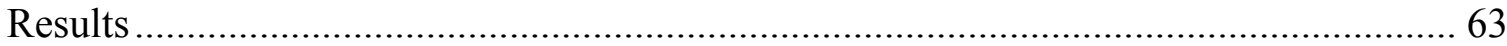

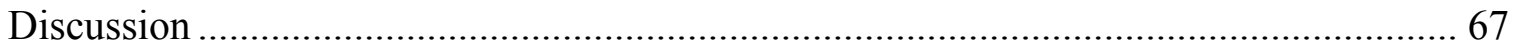

Limitations and Directions for Future Research ............................................................. 71

IV. THE IMPACT OF BUSINESS GROUP DIVERSIFICATION ON EMERGING MARKET

MULTINATIONALS: EVIDENCE FROM LATIN AMERICA. ……………………............. 74

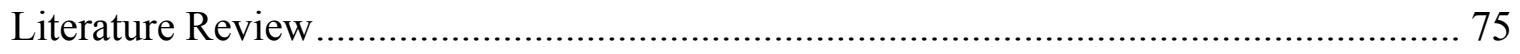

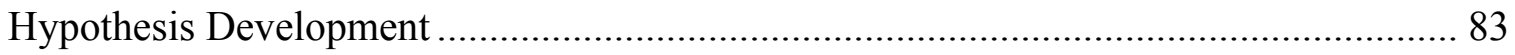

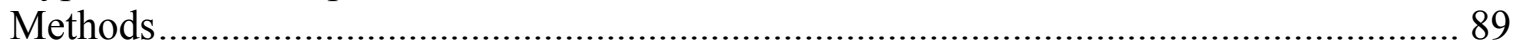

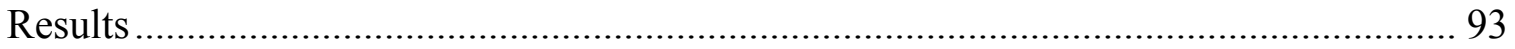

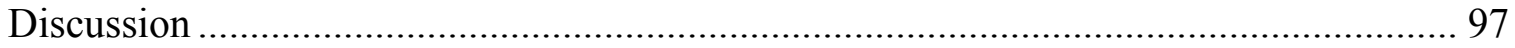

Limitations and Directions for Future Research ......................................................... 102

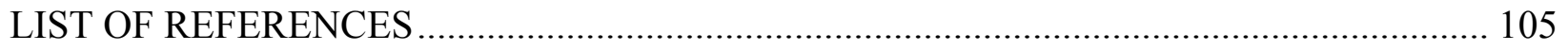

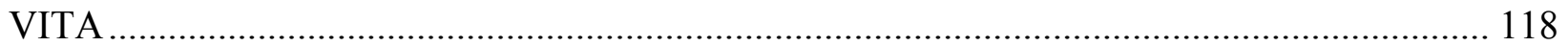




\section{LIST OF TABLES}

TABLE

PAGE

1. Descriptive statistics and correlations for variables included in essay $1 \ldots \ldots \ldots \ldots \ldots \ldots . . . \ldots 1$

2. The impact of internationalization and proposed moderating effects on firm performance.................................................................... 33

3. Multilevel Model of Change to assess impact of BG diversification on firm

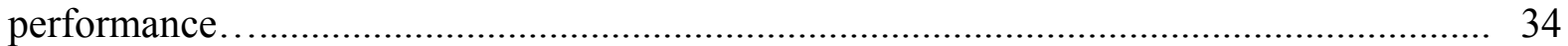

4. Descriptive statistics and correlations for variables included in essay $2 \ldots \ldots \ldots \ldots \ldots \ldots .65$

5. The impact of complexity and proposed moderating effects on firm performance...... 66

6. Descriptive statistics and correlations for variables included in essay $3 \ldots \ldots \ldots \ldots \ldots \ldots . . \ldots 4$

7. The impact of business group diversification on firm performance................... 95

8. The impact of business group diversification on firm performance by regional classification

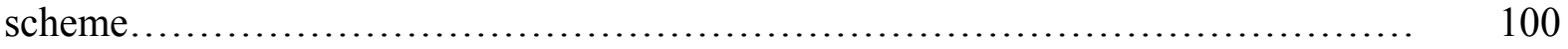




\section{CHAPTER 1}

\section{INTRODUCTION}

The predominance of diversified business groups in emerging economies (i.e. Yiu, Burton and Lu, 2005; Tan and Meyer, 2010) and the rapid internationalization of emerging market firms (i.e. Auklah, 2007; Luo and Tung, 2007; Mathews, 2006) have recently captured the interest of both international business and strategy scholars. Previous research has used the presence or absence of institutional voids and transaction cost to explain both lines of research.

On the one side, diversified business groups are assumed to be the most efficient organizational form to overcome market imperfections (i.e. Khanna and Palepu, 1997; 1999; Khanna and Rivkin; 2001). On the other side, emerging market multinationals developed because of gains in efficiency in their home countries associated with the adoption of such promarket structural reforms (i.e. Cuervo-Cazurra, 2007; Cuervo-Cazurra and Dao, 2009a; Dunning, Kim and Park, 2008). In fact, because of better resource allocation mechanisms, more capacity to access high quality resources, higher level of domestic competition and improved governance mechanisms, diversified business groups have found not only more difficulties to generate value within their home countries but also faced increasing pressures to refocus their scope of operations. However, the same type of environmental conditions has forced emerging market firms to develop a set of firm specific advantages suitable to be exploited in foreign markets.

Hence, considering this opposite effect of the progressive adoption of pro-market structural reforms on these dynamic lines of research, the main motivation of this dissertation is to disentangle the capacity of business group diversification to generate value. In particular, this 
dissertation analyzed this capacity on the internationalization process of their affiliates and its relation with firm performance.

The dissertation is organized in three essays. In the first essay (chapter 2), the dissertation assesses the nature of the multinationality and performance (M-P) relationship, the capacity of business group diversification to positively influence firm affiliated performance and the moderating effect of business group diversification on the M-P relationship. Further, we explore whether this capacity to positively influence the M-P relationship varies depending on the type of sector in which the firm participates (Manufacturing vs. Soft Service firms). In this essay, we found empirical evidence suggesting a positive effect of business group diversification on the internationalization of their affiliates. The impact is stronger at earlier stages of internationalization and for soft service firms. This essay contributes to previous literature not only by introducing relevant moderators to the M-P relationship as suggested by Bausch and Krist (2007) but also by emphasizing that business group diversification not only have location bound resources. Diversified business groups have non location bound benefits suitable to be exploited abroad. Further, the first essay explicitly explains under what conditions these benefits of business group diversification are more valuable. Our results suggest that business group diversification adds value in conditions of uncertainty.

The second essay (chapter 3) explored the capacity of business group diversification to minimize the negative effects of international complexity on firm performance. Further, considering that institutional environments have several dimensions (Wan and Hoskisson, 2003) and that the capacity of the non-market resources possessed by emerging market firms to compete abroad depends on the specific dimension analyzed (Cuervo-Cazurra and Genc; 2011), this essay explore the moderating capacity of business group diversification on different 
dimensions of international complexity. The statistical results suggest that business group diversification effectively ameliorate the relationship between international complexity and firm performance. Further, we found that business group diversification moderates the relationship between institutional voids complexity and firm performance, but not the corresponding relation between societal complexity and firm performance. Peng (2003) mentioned that there is some evidence suggesting that in the presence of institutional transitions, diversified business groups rather than downsizing the scope of operations may instead expand the scope of their operations. This essay contributes to previous research by providing empirical evidence of such behavior. Diversified business groups can distribute their large overhead by the internationalization of their affiliates. Moreover, the second essay identified the specific dimensions of international complexity in which business group diversification can add value. In the presence of institutional voids complexity, affiliated firms may have access to both non-market resources and previous international experience to minimize its negative effects on firm performance.

Our last essay (chapter 4) explored the limits of diversified business groups to deploy their non-market resources abroad. Rugman and Verbeke (2004) argued that firm specific assets have a limited capacity to be deployed abroad. Following this line of research, the third essay analyzed the impact of business group diversification on the relationship between scope of internationalization and firm performance of their affiliates and how this impact varies depending on whether their affiliates expand to more or less developed countries and on whether their affiliates are regionally or globally oriented. Our results suggest a positive moderating effect of business group diversification and that this capacity is stronger when the network of affiliated firms is located within the Americas. The third essay contributes to previous literature by emphasizing both that business group diversification provides benefits to their affiliates above 
and beyond their countries of origin and that there are limits to deploy such benefits abroad. Only affiliates that internationalized within the region can realize those benefits. Further, while Rugman and Verbeke $(2004 ; 2007 ; 2008 a ; 2008 b)$ emphasize the regionally bound nature of market base resources, this essay analyzed the impact of non-market resources provided by business group diversification.

The three essays focused on Latin America. In particular, we considered firms from Chile, Brazil and Mexico (i.e. Aulakh, Kotabe and Teegen, 2000) and a time span from 2000 to 2007. Hence, the methodology used in this dissertation is longitudinal. Two methods were used to address the hypotheses posed: on the one side, the dissertation used panel data analysis. To decide whether to use fix or random models, it was conducted the Hausman Test that favored the use of fix effects models. On the other side, the dissertation used multilevel models of time when it was necessary to test time invariant variables. According to Singer and Willet (2003), multilevel models accommodate complex error structures such as heteroskedasticity and autocorrelation.

As mentioned, a dominant explanation of the existence and capacity to generate value of diversified business groups is the presence of institutional voids and high transaction costs (i.e. Carney, Gedajlovic, Van Essen, Van Oosterhout, 2011). In this view, if these institutional voids are filled and transaction cost are reduced, the capacity of business group diversification to generate value is reduced, the large fix costs needed to manage this organizational form exceeds the potential benefits obtained and the pressures to reconfigure their activities are considerably increased (i.e. Granovetter, 2005). Further, Hoskisson, Johnson, Tihanyi and White (2005) argued that the market substitute mechanisms developed became inefficient and unnecessary and therefore, diversified business groups will fragment their operations favoring the appearance of 
individual firms. However, in this dissertation we explored and found evidence of an alternative avenue to generate value of business group diversification under the adoption of pro-market reforms. Business group diversification can distribute their large overhead by providing benefits to their affiliates in their internationalization process. In particular, these benefits are stronger when affiliated firms faced high uncertainty, when they need to deal with institutional voids complexity and when they internationalize within the Americas region. 


\section{CHAPTER 2}

FIRM INTERNATIONALIZATION, BUSINESS GROUP DIVERSIFICATION AND FIRM

PERFORMANCE: THE CASE OF LATIN AMERICAN FIRMS

The predominance of diversified business groups (i.e. Yiu, Burton and Lu, 2005; Tan and Meyer, 2010) and the rapid internationalization of emerging market firms (i.e. Auklah, 2007; Luo and Tung, 2007; Mathews, J, 2006) have recently captured the interest of both international business and strategy scholars. Emerging countries have progressively implemented pro-market structural reforms favoring economic liberalization and improving governance mechanisms (Cuervo-Cazurra and Dao, 2009b; Kim, Kim and Hoskisson, 2010). These reforms may have impacted not only the value of business groups but also the capacity of emerging market firms to internationalize. However, it seems that the implementation of such reforms affects each of these phenomena in opposite directions. On the one side, the existence of business groups has been explained as the most efficient response to the existence of large institutional voids (i.e. Khanna and Palepu, 1997; 1999; Khanna and Rivkin, 2001). On the other, the rapid internationalization of emerging market firms has been linked to the home country's adoption of pro-market structural reforms that reduces the transaction costs and agency problems which business groups are meant to help overcome (i.e. Cuervo-Cazurra, 2007; Cuervo-Cazurra and Dao, 2009a; Dunning, Kim and Park, 2008).

Recognizing the need to better understand business group internationalization in the context of recent emerging market changes, we analyze the effects of internationalization and business group diversification on firm performance. Further, given the context dependent nature of the multinationality-performance (M-P) relationship (Bausch and Krist, 2007; Contractor, Kundu and Hsu; 2007), we explore the moderating impact of business group diversification and 
how this impact varies depending on the type of sector in which the firm participates. Bausch and Krist (2007) suggested the introduction of fine grained moderators to better understand the conditions under which internationalization impacts performance. Given the seemingly opposite effects of pro-market structural reforms on the value of both internationalization and business group diversification, the impact of the latter on the M-P relationship remains unclear.

We explore these relations in the context of Latin America for several reasons. First, it is expected that the presence of emerging multinationals from the region will increase rapidly in the following years. Consistent with this argument, while growth is down in recent years due to the world financial crisis (WIR, 2010), FDI flows from the region increased almost $20 \%$ annually from 1992 to 2007 (UNCTAD, 2008), and Latin America's percentage of the world outward FDI total increased from $2.7 \%$ to $4.3 \%$ between 2007 and 2009 (WIR, 2010). Additionally, the total stock of FDI from Latin America increased more than seven times in the same period (UNCTAD, 2008) and two economies of the region (Brazil and Mexico) are expected to play a major role in the worldwide economy (Goldman Sachs, 2007).

Further, Latin America provides a special setting because most of the countries within the region have experienced extensive structural reforms at almost the same time (Brenes, 2000; Brenes and Dominguez, 1997; Cuervo-Cazurra; 2007). Cuervo-Cazurra (2008) suggested that this similarity helps not only the comparison of experiences, but also the generalizability of results within the region. Finally, Latin America has been characterized by the large presence of family business groups (Guillen, 2000). For these reasons, we believe that Latin America represents an ideal setting for our analysis.

The paper proceeds as follows. First, we review the relevant literatures associated with the multinationality-performance (M-P) relationship, business group affiliation and 
manufacturing versus service firms needed to build our theory. Next, we develop our hypotheses in the context of Latin America firms. Then, we present our methodology and results. We test our hypotheses on a sample of 103 firms from 3 countries in Latin America over the period 2000 to 2007. A total of 771 firm-year observations were collected. Finally, we discuss our results and highlight the contributions and limitations of the paper.

\section{LITERATURE REVIEW}

The multinationality-performance (M-P) relationship

Despite a major assumption in the international business literature that multinationality positively impacts business performance, empirical research has not shown consistent results (Contractor, Kundu and Hsu; 2003; Contractor, 2007; Glaum and Oesterle, 2007; Gomes and Ramaswamy, 1999, Hennart, 2007; Hitt, Hoskisson, and Kim, 1997; Sullivan, 1994; Tallman and Li, 1996). Empirically, the relationship has been found to be positive (Haar, 1989) negative (Brewer, 1981), U-shape (Qian, 1997) and inverted U-shape (Gomes and Ramaswamy, 1999).

International business scholars have attempted to explain these mixed results using different perspectives. These attempts can be broadly classified in two streams of research: one focuses on the type of measurement used (Ramaswamy, Kroeck and Renforth, 1996; Sullivan, 1994; Wiersema and Bowen, 2011); the other analyzes the form of the M-P function and its theoretical foundations (for instance, Contractor et al., 2003; Gomes and Ramaswamy, 1999; Hitt et al., 1997). In the first research stream, the main argument is that the mixed empirical results are due to the lack of reliable measures. However, Bausch and Krist (2007) argued that the contradictory results found cannot be due to different facets of internationalization since the degree to which each dimension affects performance does not differ significantly. 
The second stream of research focuses on the function of the multinationalityperformance relation. Facing these contradictory results, Contractor et al., (2003) developed a general theory of the multinationality-performance relationship. They argued that all these seemingly contradictory results can be reconciled under their proposed three-stage theory of international expansion. Essentially, they argued that previous research was capturing just part of an overall S relationship. Contractor et al. (2003) argued that at earlier stages of international expansion (stage 1), internationalization negatively impacts firm performance. When firms go abroad, they face liabilities of foreignness (Zaheer, 1995; Zaheer and Mosakowski, 1997), high learning costs (Johanson and Valhne, 1977) and high upfront costs (Contractor, 2007). These upfront costs can be amortized across only a few countries, and therefore, negatively impact performance. At a later stage of internationalization (stage 2), the benefits of international expansion are realized. The traditional arguments in favor of multinationality apply to this stage. Arguments such as monopolistic advantages (Hymer, 1976), risk reduction (Agmon and Lessard, 1977), accumulation of market power due to multinationality (Kogut, 1985), and knowledge acquired from abroad (Kogut and Zander, 1993) can be used to explain the positive slope in this part of the overall S relationship.

At excessive internationalization (Stage 3), the incremental benefits are lower than the incremental costs when firms go abroad. The arguments of transaction cost theory (Coase, 1937; Williamson, 1975) are primarily used to explain this stage of internationalization. Another argument used is the potential of the markets targeted at later internationalization stages. Firms tend to enter foreign markets with the highest potential first. However, at later stages, the potential of more peripheral markets declines and the further complexity added negatively impacts firm performance (Contractor, 2007). In general, Contractor et al. (2003) and Contractor 
(2007) argued that the length of stages 1 and 3 are shorter than that of stage 2 . Therefore, in general, internationalization is good for firms. The three stage model has been retested and empirical support was found in later studies (e.g., Lu and Beamish, 2004; Ruigrok, Amann and Wagner, 2007; Thomas and Eden, 2004).

Hennart $(2007 ; 2011)$, using TCE theories, argued that there is no a priori reason to anticipate any relation between internationalization and performance. Basically, he criticized the basic tenets used in international business to explain the impact of multinationality on firm profitability. However, empirical evidence suggests that there is a relationship between multinationality and performance after controlling for firm specific factors and considering intangible assets such as R\&D intensity and advertising intensity (Kirca et al., 2010).

The three stage model of international expansion is gaining consensus (Glaum and Oesterle, 2007). Nevertheless, since the multinationality-performance relation is assumed to be context dependent (Contractor, 2007), Bausch and Krist (2007) suggested that rather than focus on generalizations of this relationship, researchers should evaluate the impacts of fine grained moderators.

Business group diversification

Most of the literature on business conglomerates anchored in developed countries suggests that unrelated (industry or product) diversification in organizations does not add value, is inefficient, and as a consequence, leads to weaker performance compared to non-diversified ones (Khanna and Palepu, 1997, 1999, 2000a, 2000b). Nevertheless, the business group is a dominant organizational form in most emerging markets (Chakrabarti, Singh and Mahmood, 2007; Tan and Meyer, 2010; Yiu, Bruton and Lu; 2005). A business group can be defined as 'a set of firms which, though legally independent, are bound together by a constellation of formal 
and informal ties and are accustomed to taking coordinated action' (Khanna and Rivkin, 2001: 47-48). Hence, a major characteristic of a business group's affiliated firms is their propensity to act in coordination with other members of their own group.

Chatterjee and Wernerfelt (1991) argued in favor of a contingent effect associated with related or unrelated diversification. In particular, they suggested that the effect of a particular type of diversification on firm performance is contingent on the type of resources possessed by the firm and how appropriate they are to pursue a specific diversification type. Later, Khanna and Palepu (1997, 2000b) argued that the extent to which business groups add value depends on the characteristics of the 'institutional context' (Khanna and Palepu, 1997: 45) where they participate. In countries with high transaction cost, the institutional context favors a large scope of operations favoring the entrance to multiple businesses. Further, Khanna and Rivkin (2001) suggested that business group affiliation may play multiple roles whose effects cannot be fully explained by just one theory. In line with these arguments, we will explore the existence of diversified business groups using economic and sociological perspectives.

Under the economic perspective, business groups exist because of the presence of market imperfections (Leff, 1978). According to Khanna and Palepu (1999), there are two main drivers of these imperfections: the lack of reliable information and the potential conflict of interest among the parties involved. In developed countries, the presence of specialized and reliable institutions, high quality regulations and effective enforcement minimize these effects and reduce transaction costs (Khanna and Palepu, 2000a; Meyer et al., 2008). However, in emerging economies such mechanisms are either nonexistent or inefficient (Diaz-Hermelo and Vassolo, 2010) and therefore, the transaction costs are high. In institutional contexts in which transaction costs are high, business groups are more efficient organizational forms than stand-alone entities. 
Business groups may overcome the lack of reliable information in product, capital and labor markets that prevents transactions (Khanna and Palepu, 1997). For instance, business groups may leverage their reputation and image of high quality products to gain access to new markets; they can use their internally generated capital to fund ongoing or new projects or use their track record in capital markets to obtain the required funding; and they may recruit, develop and assign to different affiliated firms highly qualified managers that are scarce in this context (Khanna and Palepu, 1997, 1999, 2000a, 2000b; Khanna and Rivkin, 2001).

Further, business groups may leverage poor regulatory systems and erratic contract enforcement conditions by using their preferential access to government officials. Chang and Hong (2002) argued that one of the purposes of business groups is the appropriation of quasi rents associated with their access to privileged information. In this setting, business groups may use their political ties with bureaucrats to obtain favors that promote their presence in different industries (Khanna and Rivkin, 2001). Overall, under conditions of high transaction costs, previous research suggests a positive effect of business groups on firm performance (Hoskisson, Johnson, Tihanyi and White; 2005).

However, emerging markets have been implementing pro-market structural reforms that aim to reduce the level of transaction costs and enhance domestic competition (Cuervo-Cazurra and Dao, 2009b; Diaz-Hermelo and Vassolo, 2010; Kim et al., 2010). Pro-market reforms reduce the number of regulations and improve their quality, improve the implementation of rules, reduce discretion of government officials and reduce the overall levels of corruption (Cuervo-Cazurra, 2007; Cuervo-Cazurra and Dao, 2009a). Further, these pro-market reforms favor the development of a competitive market for managers, ease the development of external capital markets and increase the competitive pressures favoring efficiency to assure survival (Cuervo- 
Cazurra and Dao, 2009b). In this way, pro-market reforms reduce agency costs and the potential misallocation of resources. When diversified business groups face these types of environmental changes, they have strong incentives to restructure or refocus their asset portfolios to avoid excessive organizational costs and remain competitive (Hoskisson, Cannella, Tihanyi and Faraci, 2004; Hoskisson et al., 2005).

According to the sociological/neo-institutional perspective, the predominance and benefits of business group affiliation are above and beyond purely economic considerations. Guillen $(2002 ; 2003)$ argued that being part of a business group eases information sharing and organizational learning among affiliates. Further, using arguments of neo institutional theory, he argued that under conditions of uncertainty, firms tend to imitate other members of their immediate environments or 'organizational fields' (DiMaggio and Powell, 1983: 147) to justify the adoption of particular practices. Given the variety of ties shared among business group affiliates, the experience of one member may be considered relevant to the others, and hence, its behavior may affect future strategies of the other members. Granovetter (1994) suggested that within business groups, there is less risk of opportunistic behavior because of the existence of a similar moral ground that guides action. This emphasis on trust eases information flow and minimizes internal transaction costs (Khanna and Rivkin, 2001).

Manufacturing vs. Service Firms

Campbell and Verbeke (1994) argued that service and manufacturing firms not only have different patterns of internationalization but also face different challenges when they go abroad. For instance, Goerzen and Makino (2007) mentioned that while manufacturing firms extensively use exports and non-equity agreements when they internationalize, service firms use mainly foreign direct investment (Enderwick, 1989). Further, Rugman and Verbeke (2008) mentioned 
that service multinationals are more concentrated in their home region than manufacturing multinationals.

Services firms have unique characteristics that may influence such differences (Capar and Kotabe, 2003). Compared to products, services are intangible and most of them have associated simultaneous production and consumption. These characteristics affect both the perishability and heterogeneity of the services provided (Blomstermo, Sharma and Sallis, 2006). For instance, due to their intangibility, services are difficult to assess before the purchase decision (Zeithaml, Parasuraman \& Berry, 1985). The intangibility associated with services not only impacts final customer assessments of the quality provided but also the potential costs of service-related knowledge transfer within and across firms (Kogut and Zander, 1993).

Further, due to the inseparability of production and consumption of the output, human interaction plays a central role in service provision (Capar and Kotabe, 2003), impacting the capacity of service firms to monitor the quality of the output provided (Erramilli and Rao, 1993). As a consequence, there is expected to be greater variation in customer experiences with services than with manufactured goods (Skaggs and Youndt, 2004). When it is not possible to decouple production and consumption, services cannot be exported and as a consequence, they are location bound. In this situation, service firms require a physical presence from the time of the initial entry into a particular foreign market (Ekeledo and Sivakumar, 1998; Blomstermo et al., 2006). Finally, services cannot be stored (Zeithaml et al., 1985). This perishability associated with services complicates the coordination of supply and demand and leads to underutilization of existing capacity (Goerzen and Makino, 2007; Rugman and Verbeke, 2008).

Rugman and Verbeke (2008) argued that the potential of firm specific assets of service firms to be deployable abroad decays considerably more rapidly than in manufacturing firms as 
the distance to a foreign location increases. In particular, cultural, economic and regulatory distances constrain the transferability of these firm specific assets. To explain such decay, Rugman and Verbeke (2008) considered two dimensions: first, the capacity to decouple upstream and downstream activities of the value chain, and second, the capacity to locate foreign operations based on supply considerations. Manufacturing firms have more flexibility than service firms to decouple upstream and downstream activities, and as a consequence, their adaptation to host countries focuses basically on downstream activities of the value chain. On the contrary, most service firms cannot separate value added activities and hence, they need to adapt both upstream and downstream activities adding more costs and complexities to the adaptation process. Further, while manufacturing firms can determine location decisions based on solely supply considerations (i.e. cost of inputs), service firms make their decisions considering basically demand considerations.

As a consequence, service firms also experience high levels of uncertainty (Bowen and Jones, 1996). This uncertainty is magnified in the international arena. Johanson and Valhne (1977, 1990) argued that lack of knowledge and/or psychic distance affects the internationalization process and favors an incremental path. However, as noticed by Goerzen and Makino (2007), service firms need to develop a local presence to succeed in foreign markets, jumping several of the suggested stages proposed by Johanson and Valhne's $(1977,1990)$ internationalization model.

Finally, Boddewyn, Baldwin and Perry (1986) argued that it is difficult to analyze service multinationals as a whole given their variety in size and type of business. Erramilli (1990) divided services in two broad categories: hard and soft services. Hard service firms can separate upstream and downstream activities of the value chain (i.e. software firms) and hence, do not 
require that producers move to be close to the consumer (Ekeledo and Sivakumar, 1998). In this type of service firm, the strategies of manufacturing firms can be applied without much modification (Ekeledo and Sivakumar, 2004). Soft service firms cannot separate upstream and downstream activities of the value chain and require a physical presence of the service provider (Ekeledo and Sivakumar, 1998). According to the ranking of Multilatinas published by America Economia (2010), Latin American services firms are largely in the category of soft service firms. Therefore, our arguments presented in the following section primarily relate to this service firm type.

\section{HYPOTHESIS DEVELOPMENT}

In this section, we use the literature reviewed above to derive a set of hypotheses suitable to examining theory regarding internationalization, business group diversification and performance. The hypotheses will be presented in three main sections that represent the general M-P relationship, the main effects associated with diversified business groups, and finally, the moderating effects of business group diversification on such a relationship in manufacturing and services industries.

The M-P relationship in Latin American firms

MNEs from emerging markets are generally less internationalized than MNEs from developed markets, and recent FDI patterns show that this is certainly the case for Latin American MNEs. Considering the scope of operations (or number of countries where the company has subsidiaries), the UN Economic Commission for Latin America and the Caribbean (ECLAC) (2005) noted that while FDI from other emerging countries (such as Asian countries) has spread around the world, most FDI from Latin America is located in neighboring countries (WEF, 2006). Considering the degree of internationalization (measured as foreign sales to total 
sales) as an alternative approach to measuring their foreign involvement, Latin American firms also have a low scale of international operations (ECLAC, 2005).

As mentioned earlier, during initial stages of internationalization, companies face significant entrance costs that can be amortized only across a few countries. Moreover, given that the internationalization of Latin American companies has focused mainly on neighboring countries, the sizes of their target markets have been relatively small. Hence, the expected potential benefits associated with their international involvement may be insufficient to offset the incremental costs of their foreign operations. Additionally, at early internationalization stages, companies do not have significant experience in foreign markets, and hence, face large initial learning costs. Given these reasons, we could argue that the expected relationship between internationalization and performance in the context of Latin American companies is negative. Stated differently, Latin American firms predominantly occupy the first stage of the S model described earlier.

However, there are some factors that may help Latin American MNEs to overcome these difficulties and obtain a positive internationalization-performance relationship. First, it is necessary to consider the motivations of Latin American companies when going abroad. Latin American firms commonly possess two FDI motivations: market seeking (Chudnovsky and Lopez, 2004) and resource seeking (UNCTAD, 2006). Consistent with the fact that some Latin American firms may pursue these two strategy types simultaneously, Dunning (1993) argued that both these two motives are more related to asset exploiting than to asset augmenting strategies. In the case of market seeking strategies, the foreign involvement of Latin American MNEs is basically either through exports or commercial offices in the host countries. Using exporting as a main strategy to enter foreign markets, Latin American firms avoid the substantial resource 
commitment that is required when a production facility is established (Lu and Beamish, 2006). In the case of resource seeking strategies, the foreign involvement is basically through FDI. However, the main reason to invest abroad is the acquisition of raw materials at a competitive cost to assure the continued exploitation of assets used in current operations (Deng, 2003). Location advantages of foreign countries are the main determinant of this investment type.

Second, Wells (1983) mentioned that multinationals from emerging markets tend to invest in countries where they meet little challenge from rich country firms. According to ECLAC (2005), Latin American companies participate 'in niches that have been neglected or ignored by the most dynamic transnationals in the world economy' (2005: 81). Moreover, Lall (1983) explained that the nature of ownership advantages of MNEs from developed countries is different from those of developing countries. Given the characteristics of their home economies, MNEs from developing countries possess a particular set of ownership advantages that are suitable for participating in other developing markets which more traditional MNEs find unattractive.

Finally, by investing in neighboring countries, emerging multinationals from Latin America reduce considerably their environmental diversity (when compared to investments in other parts of the world). Goerzen and Beamish (2003) suggested a negative impact of environmental diversity on the capacity of the MNC to profit in its foreign ventures.

Hence, it seems that Latin American MNEs can overcome the negative effects of internationalization at relatively earlier stages thanks to their asset exploiting strategies, their cheaper access to intermediate products, their relatively low resource commitment when going international and their selection of target markets that allow them to avoid competition from 
traditional MNEs and to reduce environmental diversity faced (Chudnovsky and Lopez, 2004; ECLAC, 2005; Lall, 1983; Lu and Beamish, 2006; Deng, 2003; WEF, 2006; Wells, 1983).

As mentioned before, data collected in previous studies may have captured subsets of the overall S-curve model, and the positioning of Latin American MNEs within the overall curve needs to be considered when developing hypotheses. Given that Latin American MNEs are in the early stages of internationalization and that the third stage of the S model is reached only when MNEs have over internationalized, it is expected that the relation between internationalization and performance is best described by the first two stages in the model (i.e., a u-shape relation). Accordingly, we suggest hypothesis 1 as follows:

Hypothesis 1: There is a quadratic relation ( $U$ shape) between multinationality and performance in the context of Latin American companies.

Business group diversification and firm performance

According to the economic perspective of business group diversification described earlier, business groups exist due to the presence of market imperfections (Leff, 1978). In emerging markets these imperfections arise because of informational problems, misguided regulations and inefficient judicial systems (Khanna and Palepu, 1997) that influence both the lack of reliable information and potential conflicts of interest among partners in a proposed transaction (Khanna and Palepu, 2000a, 2000b). Under these conditions of high transaction costs, potential partners will prefer not to use market mechanisms. Diversified business groups overcome these problems by substituting and imitating market mechanisms in their home setting, generating a positive impact on firm performance.

Emerging market countries have been implementing pro-market structural reforms. However, Kim et al. (2010) argued that institutional change is a multi-stage process, not a 
discrete event. Structural reforms do not involve an immediate reduction of transaction costs. Rather, institutional conditions change relatively slowly over time.

According to Hoskisson et al. (2005), such institutional reforms affect both the overall transaction costs in the domestic market and the organizational costs incurred by diversified business groups. Cuervo-Cazurra and Dao (2009a) argued that pro-market reforms reduce the number of regulations and enhance their quality, improve consistency in the implementation of rules, reduce the discretion of government officials and reduce overall corruption levels (CuervoCazurra, 2007; Cuervo-Cazurra and Dao, 2009a). Further, pro-market structural reforms also favor the emergence of intermediaries in emerging markets, improve the existence of reliable information and improve monitoring mechanisms favoring competition and the efficiency of emerging market firms (Cuervo-Cazurra and Dao, 2009b; Diaz-Hermelo and Vassolo, 2010). For instance, Cuervo-Cazurra and Dao (2009a) argued that economic liberalization has positively impacted competitive pressures in Latin American countries. These pressures have forced Latin American firms to develop firm specific assets and improve their competitiveness. Hence, emerging market countries that have implemented pro-market structural reforms not only reduce the existing levels of transaction costs in their home countries but also increase the efficiency of resource allocation among emerging market firms. As a consequence, the potential value generated by diversified business groups has been reduced.

Moreover, higher efficiency of both internal resource allocation and corporate governance mechanisms available within diversified business groups also limit the benefits claimed by the sociological perspective of business group diversification. In particular, these efficiencies reduce the importance of trust in minimizing internal transaction costs. Granovetter (1994) argued that within business groups, there is less risk of opportunistic behavior because of 
the existence of a similar moral ground that guides action. However, the existence of stronger monitoring mechanisms reduces the room for opportunism and favors financial performance (Cuervo-Cazurra and Dao, 2009b).

Emerging countries have been implementing pro-market structural reforms aimed at reducing market failures (Cuervo-Cazurra and Dao; 2009a, 2009b) but such reforms involve long periods of time (Kim et al., 2010). Hoskisson et al. (2005) suggested that the institutional voids that favor the existence of diversified business groups are still prevalent but to a lesser degree. As a consequence, diversified business groups may still have room to add value to their affiliated firms. However, these potential benefits should be compared with the organizational costs that diversified business groups need to incur as alternative organizational forms (Khanna and Palepu, 2000a; Douma, George and Kabir; 2006). When transaction costs are reduced, the organizational costs of diversified business groups may be higher than their associated benefits. In this situation, diversified business groups are less efficient (Chacar and Vissa, 2005) and have strong incentives to refocus their activities, favoring downsizing of their scope of operations (Hoskisson et al., 2004, Hoskisson et al., 2005). These arguments suggest that under conditions of institutional changes there is an optimal scope of operations in diversified business groups after which further diversification is detrimental to firm performance. Therefore improvements in the institutional context of emerging economies not only affect the level of transaction and organizational costs but also limit the threshold for which business groups add value to firm affiliates. Hence, we argue in favor of a curvilinear relation between business group diversification and firm performance. Thus:

Hypothesis 2: There is an inverted quadratic relation (inverted $U$ shape) between business group diversification and performance in the context of Latin American companies. 
Moderating effects of business group diversification on the M-P relationship

According to the economic perspective of business group diversification, in conditions of unreliable information in product, capital and labor markets, poor regulatory regimes and erratic enforcement mechanisms, diversified business groups are considered efficient organizational forms (Khanna and Palepu, 1997). However, Meyer (2006) suggested that knowledge of institutional systems and links with government officials are specific to a particular country. Further, the extent to which business groups can use their reputations in product, capital and labor markets may be limited in foreign countries. For instance, consider the case of reputation in product markets (Kang and Yang, 2010). Not only may indigenous host country consumers not be aware of the brand name used in a company's home country, but these host country customers also could be negatively affected by the country of origin of the business group affiliate (see, e.g., Gurhan-Canli and Maheswaran, 2000). Country of origin is a perception about a country which affects a person's evaluations of products, services, brands, or companies from that country (Lampert and Jaffe, 1996). Hence, under the economic perspective, most of the claimed benefits are primarily location bound and may not affect the M-P relationship. In fact, empirical evidence suggests that business group affiliated firms tend to be more locally oriented than their standalone counterparts (Carney, Gedajlovic, Heugens, van Essen and van Oosterhout, 2011).

The sociological perspective of business group diversification emphasizes the existence of a similar moral ground among members of a particular group (in this case, a particular business group) (Granovetter, 1994). The existence of different ties favors exchange of information and therefore, encourages organizational learning among group members. DiMaggio and Powell (1983) argued that under conditions of uncertainty, firms tend to imitate the behavior of other organizations in their organizational fields. They argued that the conformation of an 
organizational field depends, among other factors, on the level of interaction, on information sharing and on mutual awareness among members. Given the extent of ties, information sharing and coordinated action, the business group represents a suitable organization form that favors imitation of behavior, especially under conditions of uncertainty.

Internationalization represents such an uncertain situation (Guillen, 2002). Despite Johanson and Valhne's (1977) contention that experiential knowledge can only be gained by direct experience, Guillen $(2002 ; 2003)$ argued that firms may learn from the experiences of others, especially from other members in the business group. In this sense, unrelated diversified business groups may provide multiple relevant examples of how to proceed in the international arena. Members of a group that entered a particular market may share information with other members of the group about not only the existing potential for new entrants but also suitable strategies to pursue in the market (Guillen 2002; 2003). Therefore, group members with international presence provide information that not only favors learning and imitation abroad but also reduces the uncertainty and risks faced by later entrants in such markets. As a consequence, we suggest:

Hypothesis 3: The relationship between multinationality and performance in the context of Latin American companies is positively moderated by business group diversification.

The degree of uncertainty varies between manufacturing and services firms (Bowen and Jones, 1996). Soft service firms, which predominate in Latin America, cannot separate upstream and downstream activities of the value chain and require a physical presence in host markets (Ekeledo and Sivakumar, 1998; Blomstermo et al., 2006). As a consequence, these service firms tend to jump several of the suggested stages proposed by the internationalization model to secure local presence (Goerzen and Makino, 2007). Given the intangible nature of knowledge involved, 
service firms face higher levels of knowledge transfer costs (Kogut and Zander, 1993) and higher risks of opportunism (Capar and Kotabe, 2003). In contrast, manufacturing firms may follow the typical stages proposed by Johanson and Valhne's (1977) model, minimizing the associated risks.

Further, in soft services, the human interaction between employees and customers is essential to the efficient delivery of the service. This close interaction limits the monitoring capacity of service firms. On the contrary, manufacturing firms separate the manufacturing, marketing and sales functions, facilitating the control of foreign operations. In fact, Rugman and Verbeke (2008) argued that the capacity of the firm specific assets of service firms to be leveraged abroad decays considerably more rapidly than the corresponding ones of manufacturing firms. On one side, while manufacturing firms may need to complement their non-location bound firm specific assets with investments in downstream activities of their value chain, soft service firms must invest in both upstream and downstream activities requiring more complex and costly adaptations to overcome the potential liabilities of foreignness faced in host countries (Rugman and Verbeke, 2008). On the other side, manufacturing firms may locate their subsidiaries based solely on supply side considerations and choose locations where it is more efficient to produce their products ( $\mathrm{Li}$ and Guisinger, 1992). In contrast to the manufacturing case, given the inseparability of production and consumption in soft service firms, their ability to optimize their decision choices based on supply arguments is fairly restrictive (Li and Guisinger, 1992). Service multinationals have basically market seeking motives that in turn determine the locations of their upstream operations ( $\mathrm{Li}$ and Guisinger, 1992). Blomstermo et al. (2006) argued that in services where it is not possible to decouple production and consumption, service MNCs 
tend to rely more on entry modes that entail higher control and higher risk, increasing the levels of uncertainty faced.

Finally, services are perishable and cannot be stored in inventories (Zeithaml et al., 1985). Manufacturing firms in contrast, may store their excess production or transfer this excess to other locations in which their products are required.

Given these arguments, we argue that soft service firms face higher uncertainty than manufacturing firms when they internationalize. This uncertainty increases the learning and other benefits of business group diversification presented in the prior hypothesis, causing this positive moderating effect to be stronger for soft service firms than for manufacturing companies. Accordingly, we hypothesize:

Hypothesis 4: The positive moderating effect of business group diversification on the relationship between multinationality and performance in the context of Latin America is stronger for soft service firms than for manufacturing companies.

\section{METHODS}

Sample

Following Aulakh, Kotabe and Teegen (2000), we select three major countries within Latin America as the focus of our study: Chile, Brazil and Mexico. To select our sample, we used two sources: the 2008 ranking of the 500 largest companies in Latin America provided by America Economia magazine and firms that are publicly traded in the NYSE. America Economia is a business related magazine founded in 1986 and is considered an important source of information in the region. However, the ranking included the largest firms in the region considering both companies headquartered in Latin America as well as outside the region (i.e. Walmart Mexico). Given that we are interested in Latin American firms, we used the corporate 
affiliations database compiled by Lexis Nexis Business Data Group to identify subsidiaries of non-Latin American firms. These firms were eliminated from the data. Next, companies from banking and financial service sectors were excluded from the sample because they do not have comparable performance measures (Ruigrok et al., 2007).

We considered the time span from 2000 to 2007 for the following reasons: On the one side, Latin American firms started the internationalization process fairly late and took a long time to become MNEs (Cuervo-Cazurra, 2008). Indeed, Latin American countries have evolved from import substitution models characterized by centralized governments, control mechanisms and lack of competition to liberalization models, where governments compete to attract FDI and to encourage competition. On the other side, availability of information (especially information related to internationalization of the firm) prevents the use of a longer time frame. Finally, we excluded firms with less than 3 years of data. As a result, our final sample covered 103 companies (51 Brazilian, 14 Chilean and 38 Mexican) over the period 2000 to 2007. A total of 771 firm-year observations were analyzed.

Dependent variable. Following previous studies, we considered various accounting based performance measures. We use return on assets (ROA) as a proxy of performance. ROA is one of the most commonly employed measures in the international business and strategy literatures (Daniels and Bracker, 1989; Gomes and Ramaswamy, 1999; Haar, 1989; Kim, Hoskisson and Wan, 2004). We disregard the use of ROE because it is more sensitive to capital structure measures (Hitt et al., 1997). We obtained the required financial information to calculate ROA from annual reports or SEC files.

Independent variables. Multinationality, business group diversification and primary industry are the most important independent variables in this study. Regarding multinationality, 
we are cognizant that it is preferable to use a multidimensional measure. However, unavailability of data regarding Latin American firms prevents the construction of indexes such as the ones used by Gomes and Ramaswamy (1999). Moreover, Bausch and Krist (2007) suggested that the different dimensions of multinationality (such as scope or scale of international operations) have similar effects on firm performance. Hence, in this study, we use a measure of the scale of foreign operations (Tallman and Li, 1996): the ratio foreign sales to total sales (FSTS). This is the most commonly used measure in the internationalization performance literature (Bausch and Krist, 2007, Contractor et al., 2007; Grant, 1987; Haar, 1989). Additionally, we introduced a quadratic term of this variable $\left(\mathrm{FSTS}^{2}\right)$ to test the hypothesized U-shape relation. To minimize multicollinearity problems, these variables were mean centered (Aiken and West, 1991).

To identify business groups in each country, we used several sources. For Brazil, we used the ranking of "the 100 maiores grupos" (the 100 biggest groups) published in 2009 by Exame Magazine (containing information of 2008). In this ranking, Exame provided a list of the main controlled companies associated with each of the groups identified. For Chile, we used the report "principales grupos empresariales Chilenos" (main Chilean Business Groups) published by Universidad del Desarrollo in 2008. We directly contacted Patricio Cortes, one of the leading authors of this report, who provided the names of the major companies associated with the 33 biggest business groups in Chile. Next, we obtained the annual reports of these major firms and identified the subsidiaries related to these companies. For Mexico, we used the ranking of "the 100 empresarios mas importantes del 2008" (The 100 most important businessmen of 2008) published by Expansion Magazine. This ranking provided the name of the major companies associated with each businessman in Mexico. Next, we obtained the annual reports of these major firms and identified the subsidiaries related to these companies. 
To capture group diversification, we followed the approach of Khanna and Palepu (2000a, 2000b) by considering the number of industries in which the business group affiliates participate. To determine the number of industries, we identified the industries in which each member of a particular group is involved (whether included or not in our sample) using the 2 digit SIC codes obtained from Compustat, Mergent or the company profiles provided by Lexis Nexis Business Data Group. When necessary, missing SIC codes were added by matching company product descriptions with the applicable SIC code. We recognized that entropy or Herfindahl measures are more accurate to portray the extent of product diversification of firms. However, unavailability of segment data prevents the accurate construction of such measures. Therefore, our measure of business group diversification (BGDIV) is the count of industries in which the group participates. This is a time invariant variable captured in 2008. Additionally, we introduced a quadratic term of this variable $\left(\mathrm{BGDIV}^{2}\right)$ to test the hypothesized inverted U-shape relation. To minimize problems of multicollinearity, these variables were mean centered (Aiken and West, 1991).

To identify whether the focal company is a manufacturing or service firm in order to test H4, we first identified its primary standard identification code from the SIC codes collected above. Next, we considered the first 2-digit codes to classify each firm as a manufacturing or service firm. This is a time invariant variable that takes the value of 1 if it is a manufacturing firm and 0 otherwise.

\section{Model Specification}

To test the hypotheses developed in this paper, we used panel data. With panel data, pooled OLS regression is not appropriate (Baum, 2006). The assumptions of normality, homoscedastic variance across occasions and individuals, and independent and identically 
distributed errors do not hold in longitudinal studies (Singer and Willet, 2003). To deal with these problems, we used panel data models. To decide whether we would use random or fixed effects, we conducted the Hausman Test that examined the hypothesis that the error term of the random effects model is not correlated with the regressors (Baum, 2006; Wooldridge, 2002). Our results rejected this hypothesis, favoring the use of fixed effects models.

However, fixed effects models drop from the models time invariant variables such as our measures of business group diversification. Thus, to test our second hypothesis, we used a multilevel model. According to Singer and Willet (2003), multilevel models accommodate complex error structures such as heteroskedasticity and autocorrelation. Singer and Willet (2003) used a pair of subsidiary models to describe how each firm changes over time and how predictors (in this case, time invariant predictors) account for differences across firms.

In our case, the level 1 model describes the expected change on performance (ROA) for each firm during the period of study. The level 2 model relates inter-firm differences in performance (ROA) with time invariant characteristics (in this case, business group diversification). Given that we are interested in the rate of change in performance rather than the intercept, our models focus on the effect of business group diversification on the slope of the individual growth trajectory. We used the "xtmixed" command in Stata to run the analysis associated with our second hypothesis.

Control variables. Following previous research, we control for company size (total assets) and company age (number of years from inception). Controls for industry (dummy variables at 2 digit codes) and country (dummies) are introduced in the multilevel model to test hypothesis 2 . Given that these variables are time invariant, they cannot be introduced in the fixed effects model. All time invariant effects are controlled by this statistical model. 


\section{RESULTS}

The final sample consists of 771 firm-year observations from 103 firms giving an average of 7.49 years of data per company. As a consequence, we are dealing with an unbalanced dataset. The fixed effect model described above helps address this problem. Table 1 presents the descriptive statistics and the correlation matrix for the variables of interest. To check for potential problems associated with multicollinearity, we analyze Variance Inflation Factors (VIF). All scores are less than 2.5, considerably lower than the standard cut off point of 10 (Hair, Anderson, Tatham, and Black, 1998). Latin American multinationals included in the sample tend to be fairly old (47 years old) and large (5,794 US\$M). Also, they are at early stages of the internationalization process. (The average scale of operations abroad as reported by the nontransformed FSTS ratio is less than 0.25.)

Table 2 presents the results of the fixed effects models used to test the main effects of degree of internationalization (H1) and the interaction effects (H3 and H4). It is important to notice that panel data models report three R-squares, of which interpretation varies depending on the type of model used. The relevant R-square for fixed effects models is the R-square within (StataCorp, 2005).

As noted earlier, we test the main effect of business group diversification (H2) using multilevel methods. Those results are presented in Table 3. To estimate the goodness of fit of multilevel models, we use the log likelihood (LL) and the deviance statistics. In general, the larger the LL, the better the fit of the model is (Singer and Willet, 2003). However, since models with more variables tend to have larger LL, we use differences in the deviance statistics corrected by the number of additional variables introduced in the model to determine whether the improvement of fit is statistically significant. In fact, the difference in deviance statistic is 
compared to the value of a $\chi^{2}$ distribution with degrees of freedom equal to the number of additional variables introduced into the model (Singer and Willet, 2003).

Table 1: Descriptive statistics and correlations for variables included in essay 1

\begin{tabular}{lrrrlrrrrrrr}
\hline Variables & Obs & Mean & S.D. & VIF & 1 & 2 & 3 & 4 & 5 & 6 & 7 \\
\hline & & & & & & & & & & \\
1. ROA & 771 & 0.05 & 0.08 & & 1 & & & & & \\
2. AGE & 771 & 47.15 & 30.05 & 1.05 & -0.01 & 1 & & & & \\
3. SIZE & 771 & 6507.76 & 24512.7 & 1.02 & -0.06 & 0.07 & 1 & & & \\
4. BGDIV & 771 & 0.00 & 5.41 & 2.09 & 0.11 & 0.17 & -0.08 & 1 & & \\
5. BGDIV & 771 & 29.33 & 54.43 & 2.08 & -0.04 & 0.18 & 0.01 & 0.71 & 1 & & \\
6. FSTS & 771 & 0.00 & 6.79 & 1.11 & 0.04 & 0.01 & 0.03 & 0.00 & 0.00 & 1 & \\
7. FSTS & 771 & 45.99 & 198.84 & 1.12 & -0.01 & 0.05 & -0.01 & 0.02 & -0.04 & 0.32 & 1 \\
\hline
\end{tabular}

Hypothesis 1 predicted a curvilinear effect of multinationality on performance in the context of Latin American multinationals. Our empirical evidence does not support this hypothesis. Neither multinationality nor its square term reach significant levels in any of the models analyzed (models 2-8). Therefore, our first hypothesis is not supported.

Hypothesis 2 predicted an inverted U-shaped relationship between business group diversification and firm performance. Table 3 presents the multilevel models used to assess this relationship. The first model is the unconditional means model and assesses whether we have variation at each level to be further modeled with more predictors. Considering the significance of the error terms (within person and initial status), we have confidence that there is still variance to be furthered modeled. The second model is the unconditional growth model that analyzes whether there are significant differences in the growth rate (slope) among the firms in the sample.

In model 3, we introduce a set of control variables (in particular country and industry dummies) to explain inter-firm differences in the rate of change. While most industries have a 
significant effect on explaining inter-firm differences on performance, country dummies failed to reach significance. Finally, in model 4, we introduce the variables of interest: Business group diversification and business group diversification squared. The coefficients of both variables are not only significant (at $\mathrm{p}<0.05)$, but also have opposite signs. It is noteworthy that when only the non-squared term is included, the coefficient reaches significance (at $\mathrm{p}<0.05$ ). Nevertheless, the model including both terms has a better fit (at $\mathrm{p}<0.05$ ). These results suggest a positive relationship at relatively low levels of diversification, but after a threshold, the relationship changes to a negative one. In fact, our results suggest that the relation remains positive when diversified business groups participate in up to nine industries (inflection point $=9.75$ industries). However, after this point, further diversification negatively impacts firm performance. Therefore, our second hypothesis is supported.

Hypothesis 3 predicted a positive moderating effect of business group diversification on the M-P relation. We test this hypothesis in Table 2 (models 3 and 4). In fact, the moderating effect of business group diversification is significant and positive for the first order variable (FSTS), but is not significant for the quadratic term $\left(\mathrm{FSTS}^{2}\right)$. These results suggest that the benefits of business group diversification are significant at the earlier stages of the internationalization process, but at later stages, those benefits tend to disappear. Hence, our third hypothesis is partially supported.

The last hypothesis argued that the positive effects of business group diversification on the M-P relationship are more important in services than in manufacturing. Given that this hypothesis involves a three-way interaction, we divided our sample into service and manufacturing firms to assess whether there are significant differences between services and manufacturing firms. 
Table 2: The impact of internationalization and proposed moderating effects on firm performance.

\begin{tabular}{|c|c|c|c|c|c|c|c|c|}
\hline \multirow{3}{*}{ Variables } & \multirow[t]{2}{*}{ Model 1} & \multirow[t]{2}{*}{ Model 2} & \multirow[t]{3}{*}{ Model 3} & \multirow[t]{3}{*}{ Model 4} & \multirow{2}{*}{\multicolumn{2}{|c|}{$\begin{array}{l}\text { Model } 6 \\
\text { ufacturing }\end{array}$}} & Model 7 & Model 8 \\
\hline & & & & & & & \multicolumn{2}{|c|}{ Services } \\
\hline & & & & & & & & \\
\hline \multirow[t]{2}{*}{ Constant } & $-0.300597 * *$ & $-0.30765^{* *}$ & $-0.29756^{* *}$ & $-0.29764 * *$ & $-0.39292 * *$ & $-0.38518^{* *}$ & $-0.22104 * *$ & $-0.23272 * *$ \\
\hline & 0.03970 & 0.04117 & 0.04125 & 0.04120 & 0.05602 & 0.05643 & 0.06456 & 0.06430 \\
\hline \multirow[t]{2}{*}{ AGE } & $0.00748 * *$ & $0.00763 * *$ & $0.00740^{* *}$ & $0.00742 * *$ & $0.00873 * *$ & $0.00857 * *$ & $0.00639 * *$ & $0.00696^{* *}$ \\
\hline & 0.00084 & 0.00087 & 0.00087 & 0.00087 & 0.00107 & 0.00107 & 0.00173 & 0.00174 \\
\hline \multirow[t]{2}{*}{ SIZE } & 0.00000 & 0.00000 & 0.00000 & 0.00000 & 0.00000 & 0.00000 & 0.00000 & 0.00000 \\
\hline & 0.00000 & 0.00000 & 0.00000 & 0.00000 & 0.00000 & 0.00000 & 0.00000 & 0.00000 \\
\hline \multirow[t]{2}{*}{ FSTS } & & -0.00015 & -0.00031 & -0.00046 & -0.00040 & -0.00047 & 0.00046 & 0.00000 \\
\hline & & 0.00032 & 0.00033 & 0.00034 & 0.00037 & 0.00037 & 0.00085 & 0.00087 \\
\hline \multirow[t]{2}{*}{ FSTS $^{2}$} & & 0.00000 & 0.00002 & 0.00001 & 0.00001 & 0.00002 & 0.00005 & 0.00005 \\
\hline & & 0.00001 & 0.00002 & 0.00002 & 0.00002 & 0.00002 & 0.00008 & 0.00008 \\
\hline \multirow[t]{2}{*}{ BGDIV*FSTS } & & & $0.0001646^{*}$ & $0.00020^{* *}$ & & 0.00009 & & $0.00031^{*}$ \\
\hline & & & 0.00007 & 0.00007 & & 0.00008 & & 0.00014 \\
\hline \multirow[t]{2}{*}{ 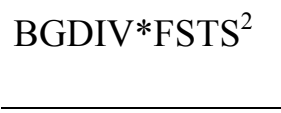 } & & & & -0.00001 & & & & \\
\hline & & & & 0.00001 & & & & \\
\hline R-sq within & 0.10590 & 0.10680 & 0.11430 & 0.11780 & 0.15310 & 0.15580 & 0.06680 & 0.08370 \\
\hline R-sq between & 0.00230 & 0.00230 & 0.00230 & 0.00260 & 0.00090 & 0.00090 & 0.08030 & 0.0682 \\
\hline R-sq overall & 0.00000 & 0.00000 & 0.00000 & 0.00000 & 0.00000 & 0.00000 & 0.01570 & 0.0126 \\
\hline $\begin{array}{l}\text { Number of } \\
\text { observations }\end{array}$ & 774 & 771 & 771 & 771 & 453 & 453 & 318 & 318 \\
\hline Number of firms & 100 & 100 & 100 & 100 & 59 & 59 & 41 & 41 \\
\hline
\end{tabular}

$+\mathrm{p}<0.10 ;{ }^{*} \mathrm{p}<0.05 ; * * \mathrm{p}<0.01$ 
Table 3: Multilevel Model of Change to assess impact of BG diversification on firm performance

\begin{tabular}{|c|c|c|c|c|c|}
\hline & & Model 1 & Model 2 & Model 3 & Model 4 \\
\hline \multicolumn{6}{|l|}{ Fixed effects } \\
\hline Initial Status & Intercept & $0.05375^{* *}$ & $0.02781^{* *}$ & $0.02784 * *$ & $0.02793 * *$ \\
\hline \multirow[t]{6}{*}{ Rate of Change (Slope) } & Intercept & & $0.00723^{* *}$ & $-0.01030^{*}$ & $-0.00948 *$ \\
\hline & Mixed In & try effects*** & & & \\
\hline & Brazil & & & 0.00289 & $0.00349^{*}$ \\
\hline & Chile & & & 0.00001 & -0.00169 \\
\hline & $\begin{array}{l}\text { BGDIV } \\
(\mathrm{H} 2) \\
\text { BGDIV }^{2}\end{array}$ & & & & $0.00078^{* *}$ \\
\hline & $(\mathrm{H} 2)$ & & & & $-0.00004 *$ \\
\hline \multicolumn{6}{|l|}{ Variance Components } \\
\hline \multirow[t]{2}{*}{ Level 1} & Within Person & 0.00301 & 0.00213 & 0.00213 & 0.00213 \\
\hline & Variance & $(.0001613)$ & $(.0001249)$ & $(0.0001245)$ & $(.0001243)$ \\
\hline \multirow[t]{6}{*}{ Level 2} & In Initial Status & 0.00150 & 0.00245 & 0.00248 & 0.00249 \\
\hline & & $(.0002648)$ & $(.0005025)$ & $(.0005064)$ & $(.0005084)$ \\
\hline & In rate of Change ( & ope) & 0.00010 & 0.00008 & 0.00008 \\
\hline & & & $(.000023)$ & $(.0000216)$ & $(.0000216)$ \\
\hline & Covariance & & -0.00029 & -0.00033 & -0.00035 \\
\hline & & & $(0.0000927)$ & (.0000946) & $(.0000954)$ \\
\hline \multicolumn{6}{|l|}{ Goodness of fit } \\
\hline Log Likelihood (LL) & & 1103.17 & 1169.0668 & 1189.7193 & 1197.5 \\
\hline Deviance & & -2206.34 & -2338.1336 & -2379.4386 & -2395 \\
\hline Dev_diff & & & 131.7936 & 41.305 & 15.5614 \\
\hline df: & & & 2 & 21 & 2 \\
\hline$\chi^{2}(0.01)$ & & & 9.21 & 38.9 & 9.21 \\
\hline Number of observations & & 798 & 798 & 798 & 798 \\
\hline Number of firms & & 103 & 103 & 103 & 103 \\
\hline
\end{tabular}

$+\mathrm{p}<0.10 ;{ }^{*} \mathrm{p}<0.05 ; * * \mathrm{p}<0.01$

*** Results available upon request

We test this hypothesis in models 5, 6, 7 and 8 in Table 2. Models 5 and 7 can be considered base models for manufacturing and services respectively. The effects of business group diversification are introduced in models 6 and 8. Our results suggest significant differences in the importance of business group diversification between manufacturing and service firms. In manufacturing firms, business group diversification does not moderate the M-P 
relation. However, there is a positive and significant effect of business group diversification for soft service firms $(p<0.05)$. Further, while the increment in the coefficient of determination $\left(R^{2}\right)$ associated with manufacturing firms is almost negligible (0.0027), there is a noteworthy increment in the case of services firms as can be seen from models 7 and 8 (0.01690). Considering both, the significance of the coefficient in service firms and the associate increase in the coefficient of determination, we believe that hypothesis 4 is supported.

Overall, we found full support for two of our hypotheses and partial support for a third hypothesis.

\section{DISCUSSION}

Recognizing the need to better understand business group internationalization in the context of recent emerging market changes, we analyzed the effects of internationalization and business group diversification on firm performance. While we did not find a significant direct effect of internationalization on firm performance in our Latin American sample, we did find an inverted U-shaped relationship between business group diversification and firm performance. Moreover, we found a partial moderating effect of business group diversification on the M-P relationship where the benefits of business group diversification are significant at the early stages of the internationalization process, but at later stages, these benefits tend to disappear. Finally, we found that the positive effects of business group diversification on the M-P relationship are more important in soft services than in manufacturing. Overall, these results provide insights into the complex nature of the M-P relationship in Latin America in the context of business groups.

Delving more deeply into our individual results, the lack of a significant direct effect of internationalization on firm performance in our Latin American sample may be due to the fact that the FSTS ratio is relatively low. However, it may also highlight the importance of the 
introduction of fine grained moderators of this relationship. Bausch and Krist (2007) suggested investigating the conditions under which internationalization will impact performance. In this article, business group diversification is a major determinant for Latin American firms to obtain profits from their internationalization efforts.

Our second finding of an inverted U-shaped relationship between business group diversification and firm performance is consistent with literature noting that business groups exist due to the presence of market imperfections (Leff, 1978; Khanna and Palepu, 1997) that create transaction costs (Khanna and Palepu, 2000a; 2000b). Diversified business groups overcome these problems in Latin America by substituting and imitating market mechanisms. However, given the progressive change of the institutional context in Latin American countries, we believe that the costs of conducting transactions in the market place have been reduced but not eliminated. Under these conditions, diversified business groups still have the capacity to generate value, but this capacity is limited up to a certain point. Diversified business groups will find more difficulties in generating value by substituting and imitating market mechanisms once market failures have been reduced.

Our third finding suggests that the benefits of business group diversification are significant at the earlier stages of the internationalization process, but at later stages, those benefits tend to disappear. This result is consistent with prior scholars who have noted that at earlier stages of international expansion, internationalization negatively impacts firm performance (Contractor et al., 2003). As firms at this stage of internationalization are more likely to face liabilities of foreignness (Zaheer, 1995), high learning costs (Johanson and Valhne, 1977) and high upfront costs (Contractor, 2007), the benefits achieved through business group diversification may be more impactful. Later, as firms transcend into the major upward trending 
portion of the multinationality-performance (M-P) s-curve, they may have already developed capabilities to overcome these difficulties and are less in need of the additional benefits provided by business group diversification. Since few Latin American firms potentially fall into the final segment of the s-curve, where the benefits of business group diversification may once again become impactful, it is not surprising that we only see benefits in the early stages of our analysis.

Our final hypothesis examined differences between service and manufacturing firms, finding that the benefits of business group diversification on the M-P relationship are much more prominent in service firms. Due to multiple characteristics of service firms, such as the intangible nature of their knowledge (Zeithaml et al., 1985), the inseparability of production and consumption (Capar and Kotabe, 2003), their perishable nature (Zeithaml et al., 1985) and the high decay rate of their firm specific assets when deployed overseas (Rugman and Verbeke, 2008), service firms face higher uncertainty than manufacturing firms when they internationalize. Our results certainly are in line with these previously established service firm characteristics and suggest that business group diversification is a strong asset of firms in overcoming these difficulties in Latin America.

Overall, given the context dependent nature of the multinationality-performance relation (Bausch and Krist, 2007; Contractor et al., 2007), this paper set out to explore the moderating impact of business group diversification and how this impact varies depending on the type of sector in which the firm participates. In doing so, we have followed the suggestion of Bausch and Krist (2007) to introduce fine grained moderators to better understand the conditions under which internationalization impacts performance. By demonstrating that business group diversification moderates this relationship and that this relationship varies depending upon 
whether a firm is in a service or manufacturing industry, we have contributed to this stream of literature.

At the beginning of the article, we mentioned that pro-market structural reforms have seemingly opposite effects on the value of both internationalization and business group diversification and hence, the impact of the later on the M-P relationship remains unclear. This paper helps to clarify this impact. Diversified business groups have a positive impact on the M-P relationship under conditions of uncertainty. The more uncertainty, the higher the positive effect is. Internationalization is an uncertain process (Guillen, 2002). Business group diversification impacts such a relation at relatively early stages, but failed to reach significance later. Further, the effect of business group diversification on the M-P relationship is stronger for service firms than for manufacturing ones. Considering that most of the arguments associated with the economic perspective of business group diversification are location bound, the positive benefits of business group diversification are more related to the sociological perspective. Benefits such as imitation, exchange of information and learning among business group affiliates are not location bound and are more valuable under conditions of uncertainty. After firms are more seasoned internationally, these effects are relatively less important and the benefits of diversified business groups vanish. This finding also has managerial implications. Managers of firms affiliated with diversified business groups may be better off than stand-alone firms. By relying on the previous internationalization experience of other members of the same group, these managers may be able to better devise suitable strategies under conditions of uncertainty that enable them to gain the benefits of internationalization faster than stand-alone entities. In particular, this advantage is conferred upon members of business groups in the early stages of internationalization as well as in countries where institutions are not fully developed. 


\section{LIMITATIONS AND DIRECTIONS FOR FUTURE RESEARCH}

Recent studies suggest that there are substantial limits to deploying internationally the firm specific assets possessed by MNEs. For that reason, most MNEs tend to remain regionally bounded (Rugman and Verbeke, 2004; 2005; 2007; 2008). Given that in this paper we found evidence about the importance of diversified business groups under conditions of uncertainty, future research should analyze the extent to which business group diversification helps in the further internationalization of emerging market firms above and beyond their region of origin. Further, in this paper we failed to find significant direct effects between multinationality and firm performance. Verbeke, Li and Goerzen (2009) argued that the assumption of similar internationalization motivations and the failure to recognize both organizational and environmental complexity may obscure a clear understanding of the impact of internationalization on firm performance. Future research should account for such issues.

We found evidence for an inverted $U$ shape relationship between business group diversification and firm performance providing support to the economic perspective associated with business groups. Further, Khanna and Palepu (2000a) suggested that the value added potential of diversified business groups should be reduced as the level of transaction costs is reduced. However, Kim et al. (2010) cautioned that to generalize the results in different emerging economies, it is necessary to account for differences in the evolution of the institutional context.

Finally, we found support for differences between manufacturing and soft service firms. Our results do not account for differences between manufacturing and hard service sectors or between soft and hard service firms. An interesting avenue for future research is to explore the differential effect of internationalization and business group diversification in these settings. 
Our results need to be interpreted with caution. First, we relied on three different publications with different methodologies to define business group diversification across our three country locations. While we took efforts to ensure consistency across the samples, this may nonetheless affect the reliability and comparability of the information collected. Second, to capture diversification and group membership, we used only a count measure of SIC codes and dummy variables similar to the one used by Khanna and Palepu (2000a, 2000b). Since it was not possible to determine the level of sales per each SIC code, our measure may have low construct validity due to problems of deficiency and contamination. In general, a major limitation of research in Latin America in general is the availability of data. Information about Latin American firms is fragmented and incomplete. Therefore, our capacity to build adequate measures of internationalization and product diversification is fairly restrictive.

Third, the sample was drawn from the ranking of the biggest firms in Latin America. Moreover, as shown in Table 1, the companies included tend to be fairly old and diversified. Therefore, lack of variability in our sample may prevent capturing the impact of our independent variables on firm performance.

Finally, we agree with Ruigrok et al. (2007) regarding the inclusion of fine grained moderators. We introduced business group diversification as a moderator of the M-P relation. The introduction of other moderators or the refinement of the moderators included in this paper should help to improve the potential explanation of the models developed. This is an avenue for future research.

Emerging markets have been implementing structural reforms that affect in opposite directions both the capacity of diversified business groups to generate value and the ability of firms to internationalize. In this article, we fail to find significant main effects of 
internationalization on firm performance. However, given the reduction of transaction costs in these economies and the organizational costs faced by diversified business groups, we found evidence for an inverted U-shape relationship between business group diversification and firm performance. We assessed the impact of business group diversification on the M-P in the context of Latin American firms. Our findings suggest that diversified business groups may generate value to the internationalization strategies of emerging market firms. In particular, we found evidence that business group diversification generates value under conditions of uncertainty, specifically at early stages of internationalization and on the internationalization of soft service firms. Our results contribute to prior research by showing the impact of business group diversification on the internationalization strategies of Latin American firms. 


\section{CHAPTER 3}

MANAGING THE COMPLEXITIES OF INTERNATIONALIZATION: ASSESSING THE IMPACT OF BUSINESS GROUP DIVERSIFICATION. EVIDENCE FROM LATIN AMERICA.

Diversified business groups are the dominant organizational form in most emerging economies (Khanna and Palepu, 1999; Khanna and Palepu, 2000a; Khanna and Rivkin, 2001; Khanna and Yafeh, 2005; Khanna and Yafeh, 2007; Yiu, Lu, Bruton and Hoskisson, 2007). In the presence of large institutional voids, diversified business groups represent the most efficient organizational form to minimize the transaction costs prevailing in the focal market. (Khanna and Palepu, 1999; Khanna and Palepu, 2000b).

However, emerging markets have been progressively implementing pro-market structural reforms aiming to create more open and competitive markets (Kim, Kim and Hoskisson, 2010). These reforms increase foreign and domestic competition (Cuervo-Cazurra, 2007; 2008; Diaz Hermelo and Vassolo, 2010; Thomas and D'Aveni, 2004), support the efficiency of emerging market firms (Cuervo-Cazurra and Dau, 2009a), improve regulations and their implementation (Diaz Hermelo and Vassolo, 2010), limit the role of governments to facilitate transactions and as a consequence, minimize both transaction and agency costs (Cuervo-Cazurra and Dau, 2009a; 2009b).

According to Chakrabarti, Vidal and Mitchell (2011), the existence of market oriented institutions impose pressures on emerging market firms to reconfigure their portfolio of assets. Indeed, previous research on business groups stressed the importance of balancing organizational costs with the benefits of unrelated diversification and suggested these groups to reduce their portfolio of businesses in which they conduct operations. For instance, Khanna and Palepu 
(2000a) mentioned that under conditions of institutional changes and reduced transaction costs, the capacity of business groups to generate value through internalizing unrelated activities is fairly reduced. Further, Hoskisson, Johnson, Tihanyi and White (2005) argued that as emerging economies implement pro-market reforms their economic systems have become more efficient and have made business groups' market-substitute mechanisms inefficient or unnecessary. Since the creation of internal mechanisms of management, coordination and control represents large fixed costs (Khana and Palepu, 2000a), business groups face strong incentives to refocus their activities and avoid excessive organizational costs.

An alternative for diversified business groups to distribute their large overhead might be to explore international markets. Nevertheless, as mentioned by Yiu et al. (2007), there is a paucity of research associated with the internationalization of business groups. While several of the benefits provided by diversified business groups seems to be location-bound (Tan and Meyer, 2010; Meyer, 2006), empirical evidence is not conclusive about the impact of diversified business groups on the internationalization of their affiliates.

For instance, Kim et al. (2010) found that at later stages of pro-market reforms diversified business groups positively impact the relation between internationalization and performance. They suggested that during this period, business group affiliated firms are not only fully aware of the need of building market based resources to compete in the international arena but also better positioned to create them. Further, Cuervo-Cazurra and Genc (2008) found that since emergingmarket firms have developed non market resources and have learned how to operate in difficult institutional environments, they have a competitive edge over developed country multinationals when they participate in less developed economies. While they do not directly mention the impact of business groups on these competitive advantages, it is noticeable that these non-market 
resources are clearly related with the ones possessed by business groups to generate value (Khanna and Palepu, 1997; 1999; 2000a).

Hence, in this article we explore an alternative route that diversified business groups have to distribute their large fixed costs and generate value: the internationalization of their affiliates. Since the process of internationalization entails higher levels of institutional complexity (Goerzen and Beamish, 2003) and that this complexity not only entails higher costs (Goerzen and Beamish, 2003; Verbeke, Li and Goerzen, 2009) and uncertainty (Tihanyi, Griffit and Russell, 2005), but also imposes greater challenges to gain and maintain legitimacy (Kostova and Zaheer, 1999), we explore the capacity of business group diversification to ameliorate the negative effect of institutional complexity on firm performance.

We explore these relations in the context of Latin America for several reasons. First, Latin America has been characterized by the large presence of family business groups (Guillen, 2000). Second, Latin American countries have experienced extensive structural reforms at almost the same time (Brenes, 2000; Brenes and Dominguez, 1997; Cuervo-Cazurra; 2007). Latin American countries followed an import substitution model until the 1980s. In late 1980s and early 1990s, these countries implemented large pro-market structural reforms (Kuczynski and Williamson, 2003). Finally, it is expected that the presence of emerging multinationals from the region will increase rapidly in the following years (i.e. UNCTAD, 2008; 2010). For these reasons, we believe that Latin America represents an ideal setting for our analysis.

The paper proceeds as follows. First, we review the relevant literature related to both the relationship between internationalization, institutional complexity and firm performance and business group diversification needed to build our theory. Next, we develop our hypotheses in the context of Latin America firms. Then, we present our methodology and results. We test our 
hypotheses on a sample of 62 firms from 3 countries in Latin America over the period 2000 to 2007. A total of 422 firm-year observations were collected. Finally, we discuss our results and highlight the contributions and limitations of the paper.

\section{LITERATURE REVIEW}

Multinationality, Institutional Complexity and Firm Performance

Empirical research has shown inconsistent results about the impact of multinationality on firm performance (Contractor, 2007; Contractor, Kundu and Hsu; 2003; Glaum and Oesterle, 2007; Gomes and Ramaswamy, 1999; Hennart, 2007; 2011; Hitt, Hoskisson and Kim, 1997; Sullivan, 1994; Tallman and Li, 1996). To reconcile these mixed findings, Contractor et al. (2003) developed a general theory of the multinationality-performance relationship. Essentially, they argued that the effects of multinationality on performance follow a sigmoid function and hence, they proposed a three stage theory of international expansion. At earlier stages of internationalization, multinationality negatively impacts firm performance. Later, the claimed benefits of international expansion are realized. However, these benefits of internationalization have a threshold. Once companies exceed this threshold, the marginal costs exceed the marginal benefits of internationalization and hence, firms may overinternationalize. Contractor et al. (2003) argued that previous research captures just part of the overall sigmoid function and this may be the explanation for these mixed findings. According to Glaum and Oesterle (2007), the general theory of the sigmoid multinationality-performance relationship is gaining consensus.

However, a recent stream of research argued that the attempts to search for general theories to explain the multinationality-performance relationship are inappropriate. Hennart $(2007 ; 2011)$ using internalization theories argued that there is no a priori reason to expect that multinationality positively impacts firm performance. Hennart $(2007 ; 2011)$ attacked the main 
arguments used to explain the possible impact of multinationality on firm performance and argued that MNCs are inefficient mechanisms to minimize risks, that economies of scale depend on whether domestic markets are large enough to reach minimum efficient scale and not on internationalization per se, that internationalization is not the only or more efficient alternative to access high quality inputs and that learning from international operations is restricted since most foreign affiliates are establish to exploit existing knowledge within the firm. While Contractor (2007) responded to these criticisms, he also recognized that the nature of the multinationalityperformance relationship is context dependent.

Verbeke, Li and Goerzen (2009) mentioned that to assess the impact of internationalization on firm performance it is necessary to consider not only the degree of internationalization but also the motivations to internationalize and the complexity associated to this process. Further, Goerzen and Beamish (2003) argued that previous research on multinationality-performance fails to consider the diversity of institutional environments as if country differences do not matter. Nevertheless, as Kostova and Zaheer (1999) mentioned, to have presence in multiple countries with different institutional environments increases the institutional complexity faced by MNCs. A higher level of institutional complexity represents higher costs for MNCs (Goerzen and Beamish, 2003; Verbeke, Li and Goerzen, 2009), affects their capacity to establish and maintain legitimacy (Kostova and Zaheer, 1999) and increases their uncertainty by operating in different markets (Tihanyi, Griffith and Russell, 2005).

On the one side, MNCs face higher costs because host country dissimilarities increase managerial and coordination costs, prevent a proper understanding of the requirements to compete and reduce the effectiveness of the responses used by foreign subsidiaries (Zaheer, 1995; Zaheer and Mosakowski; 1997). Further, MNCs may organize their operations to be 
highly responsive to local markets trying to be isomorphic to host country demands or to be highly integrated by standardizing global operations (Prahalad and Doz, 1987; Jarillo and Martinez; 1990; Taggart; 1997). While the former type of organization entails higher internal costs, the latter involves greater external costs due to higher liabilities of foreignness (Goerzen and Beamish; 2003).

On the other side, in the presence of environmental complexity, MNCs face strong challenges to establish and maintain their legitimacy (Kostova and Zaheer, 1999). According to Kostova and Zaheer (1999), institutional environments are not only fragmented within countries but also they are different between countries because they tend to be country specific. Hence, given the diversity of domains, authorities and regulations, MNCs face multiple institutional environments and achieving isomorphism and later legitimacy is difficult.

Wan and Hoskisson (2003) argued that institutional environments can be explained by considering legal, political and societal dimensions. However, in the presence of poor regulations, erratic enforcement, large government intervention and predominance of corruption, institutional voids are prevalent (Hoskisson et al, 2005; Khanna and Palepu, 2000b). Given that the political and legal dimensions are closely related to the prevalence of institutional voids in the market place (i.e. Khanna and Palepu, 2000b), we will join both dimensions in one.

Cuervo-Cazurra and Genc (2011) argued that the extent to which emerging market multinationals (EM-MNCs) face advantages or disadvantages abroad is contingent upon the dimension being analyzed. Given that complexity measures depend on the use of distance measures (Goerzen and Beamish, 2003; Kostova and Zaheer; 1999) and considering that Berry et al. (2010) suggest analyzing the various distance components associated with our phenomenon 
of interest, we will explore the impact of business group diversification (and its non-market resources) on complexity measures associated with institutional voids and societal dimensions.

Diversified Business groups

Khanna and Rivkin (2001) define a diversified business group as 'a set of firms which, though legally independent, are bound together by a constellation of formal and informal ties and are accustomed to taking coordinated action'. There are three main characteristics that distinguish diversified business groups from other organizational forms: First, these legally independent firms do not operate autonomously. In contrast, they possess strong relations with other business group affiliated firms that allows them to work in coordination and act as a unit (Chung, 2001). Second, while firms associated with a business group are linked through multiple types of ties, the social ones have a predominant role (Yiu et al., 2007). Finally, diversified business groups normally possess a core entity that provides not only common administrative and financial control but also managerial coordination among member firms (Khanna and Rivkin, 2001). This core entity has greater autonomy and control over resources than other member firms, has better access to relevant information and key contacts and as a result, has a larger influence on other members firms (Yiu et al., 2007). All these internal mechanisms of management and control inherent to diversified business groups represent large fixed costs (Khanna and Palepu, 2000a) that must be distributed among several units to remain efficient.

According to Khanna and Palepu (1997; 2000b), the capacity of diversified business groups and their internal mechanism to generate value depends on the conditions associated with the "institutional context" (Khanna and Palepu, 1997:45) in which they participate. Previous research examines different types of institutional contexts and theoretical lenses to explain both the origin and the capacity to generate value of these organizational forms. Khanna and Rivkin 
(2001) stress the need to use different lenses to capture the multiple roles played by diversified business groups. In line with these arguments, we assess economic and sociological perspectives to explain the existence and potential value generation of business group diversification.

The economic perspective:

Leff (1978) argued that diversified business groups represent substitutes of market mechanisms in the presence of market imperfections. Under this perspective, external markets and diversified business groups represents alternative mechanisms to conduct transactions (Williamson, 1975). The choice of governance mode depends on the level of transaction costs associated with each organizational form (Coase, 1937; Williamson, 1975).

There are two main sources behind these market imperfections: the lack of reliable information in the institutional environment and the potential conflict of interest among parties (Khanna and Palepu, 1999). In the presence of intermediate institutions with high quality regulations and consistent enforcement, market transactions represent an efficient mechanism to allocate resources. Under these conditions, the benefits associated with unrelated diversification are fairly limited (Khanna and Palepu, 2000a; 2000b).

However, when these institutions are non-existent or when they are inefficient, there are strong incentives for firms to internalize transactions (Guillen, 2000). In these situations, external markets are plagued with "institutional voids" (Khanna and Palepu, 2000a: 270) that generate inefficient factor markets, inadequate information for product markets and a weak legal infrastructure to enforce contracts (Yiu et al.,2007). Under these conditions, business groups represent a more efficient organizational form by internalizing market transactions within the firm. Business groups create internal mechanisms to overcome the existing difficulties in the 
market place that prevent transactions among independent firms (Guillen, 2000; Khanna and Palepu, 1997).

The benefits of conducting transactions within the diversified business groups associated with the transaction costs in the institutional environment must be compared with the organizational costs associated with the maintenance of those market-substitute mechanisms used extensively by the core entity (Hoskisson, Cannella, Tihanyi and Faraci, 2004; Hoskisson et al., 2005).

Moreover, diversified business groups may be a mechanism used by states and governments to reach not only economic objectives but also political ones (Yiu et al., 2007). Alternatively, governments passively encourage the formation of diversified business groups with the predominance of corruption and government intervention in their country (Hoskisson et al., 2005). In this type of institutional environment, governments have the capacity to change the existing regulations (Holburn and Zelner, 2010) or influence the enforcement of judicial decisions. Diversified business groups that have preferential access to government officials may be encouraged to use these political capabilities to enter multiple industries in order to leverage these connections and benefit from them (Ghemawat and Khanna, 1998).

The impact of these non-market resources or market substitute mechanisms on the internationalization process of a business-group's affiliated firms is not clear. On the one side, Meyer (2006) suggested that knowledge of institutional systems and links with government officials are specific to a particular country. On the other side, Henisz (2003) argued that while micro-level routines to deal with political hazards are location bound, firms might also develop meta-level routines to operate in such environments. Holbrun and Zelner (2010) argued that home country environments influence the development of political capabilities that help in the 
international process of firms into politically hazardous countries. Further, Delios and Henisz (2003) suggested that previous experience in politically hazardous countries minimizes the perceived risks associated with new entries into similar countries. Finally, Cuervo Cazurra (2006) argued that the deterring effect of corruption in FDI is not homogeneous for MNEs from different countries. Firms where home governments are highly corrupt find it attractive to invest into similar countries.

The sociological perspective

According to this perspective, to understand diversified business groups and their performance, scholars need to consider not only economic factors derived from efficiency and competition, but also the social, legal, political and normative structures existing in the institutional environments in which they developed (Granovetter,1994; 2005). Biggart and Guillen (1999) proposed that countries have different "institutional logics" that might favor the emergence of business groups and Guillen (2000) argued that the main assumption under the sociological perspective is that dominant organizational forms are the result of existing isomorphic pressures in the environment. Further, Yiu et al. (2007) argued that in examining a focal country under the sociological perspective, it is important to consider the predominant authority relations and whether they are built on institutionalized cultural or social practices.

Guillen (2000) explained that diversified business groups tend to proliferate in countries with vertical social relations. In these countries, family domination is one of the most important sources for generating group identity (Granovetter, 2005) and as a result, members of affiliated firms possess a strong sense of loyalty to their main leaders (Guillen, 2000). Further, group identity and its associated sense of loyalty in diversified business groups encourages sharing of information among affiliated firms, eases organizational learning among group members and 
reduces the risk of potential disputes (Guillen, 2002; 2003; Khanna and Palepu, 1999). Therefore, within business groups there is less risk of opportunistic behavior because of the existence of a similar moral ground that guides action (Granovetter, 1994) and hence, internal transaction costs are minimized (Khanna and Rivkin, 2001).

Moreover, using arguments of neo institutional theory, Guillen $(2002 ; 2003)$ argued that under conditions of uncertainty, firms tend to imitate other members of their immediate environments or 'organizational fields' (DiMaggio and Powell, 1983: 147) to justify the adoption of particular practices. Given the variety of ties shared among business group affiliates, the experience of one member may be considered relevant to the others, and hence, its behavior may affect future strategies of the other members.

\section{HYPOTHESIS DEVELOPMENT}

In this section, we use the literature review described above to derive a set of hypothesis suitable to assess the impact of business group diversification on the internationalization processes of their affiliates. In particular, we explore the capacity of these groups to ameliorate the negative effect of institutional complexity on firm performance.

The impact of complexity on performance.

The complexity associated with foreign expansion in multiple countries increases the managerial and coordination costs faced by multinationals, it reduces the capacity to understand appropriate responses to competition in those markets and it decreases the ability to gain and maintain legitimacy in foreign countries (Goerzen and Beamish, 2003; Verbeke et al., 2009; Kostova and Zaheer, 1999).

MNCs face higher costs because host country dissimilarities increase managerial and coordination costs, prevent a proper understanding of the requirements to compete and reduce 
the effectiveness of the responses used by foreign subsidiaries (Zaheer, 1995; Zaheer and Mosakowski; 1997). Further, in the presence of institutional complexity, MNCs face strong challenges to establish and maintain their legitimacy (Kostova and Zaheer, 1999). According to Kostova and Zaheer (1999), institutional environments are not only fragmented within countries but also they are different between countries because they tend to be country specific. Hence, given the diversity of domains, authorities and regulations, MNCs face multiple institutional environments and achieving isomorphism and later legitimacy is difficult. As a consequence, our baseline hypothesis suggests a negative relationship between environmental complexity of the network of markets where an MNC has operations and firm performance. Hence,

Hypothesis 1: There is a negative relationship between institutional complexity and firm performance.

The impact of business group diversification on the relationship between institutional complexity and performance.

Kostova and Zaheer (1999) argued that, at the MNE level, institutional complexity can be understood by the number of countries in which the firm operates and the heterogeneity across countries in particular institutional dimensions. Thus, we will first explore the moderating effect of business group diversification on the relationship between the overall institutional complexity and firm performance. However, Cuervo-Cazurra and Genc (2011) argued that the extent to which EM-MNCs (and their non-market resources) face advantages abroad depends on the specific institutional dimension analyzed. Hence, to further clarify the effect of business group diversification and the relative importance of their different available mechanisms to generate value, we assess its impact on two dimensions of environmental complexity: one associated with the variation on institutional voids and the other related with the variation in societal institutions. 
Aggregate institutional complexity:

The number of different countries may represent an aggregate component of institutional complexity that does not allow the discrimination among particular dimensions of the institutional environment. According to the UN Economic Commission for Latin American and the Caribbean (ECLAC) (2005), the internationalization of Latin American firms rely not only on low commitment strategies but also on targeting other Latin American countries. Latin American countries have experienced extensive structural reforms at almost the same time (Brenes, 2000; Brenes and Dominguez, 1997; Cuervo-Cazurra; 2007) evolving from an import substitution model until the 1980s to the implementation of pro-market reforms in early 1990s (Kuczynski and Williamson, 2003). Hence, these countries have followed a relatively similar process of institutional transition. Further, countries within the region are considered to be culturally close. For instance, Ronen and Shenkar (1985) argued that, besides Brazil, most Latin American countries belong to the same cultural cluster.

There are several mechanisms through which business group diversification may impact the relationship between the aggregated measure of institutional complexity and firm performance. Diversified business groups might use their non-market resources developed at home to positively impact the internationalization of their affiliates. Given the position of the core entity, its privileged access to relevant information, the control of valuable resources and key contacts and its influence on other member firms, it is in the core entity where most of the non-market resources available in the diversified business group reside. For instance, in the presence of institutional transitions, the level of uncertainty and complexity is magnified (Peng, 2003; Peng, Lee and Wang; 2005). Diversified business groups may use their political capabilities developed at home to identify relevant actors abroad and obtain favorable treatment. 
Peng (2003) proposed that the adoption of formal market reforms require emerging economies to develop relevant institutions. Emerging economies lack of both enough rules to govern market transactions and credible mechanisms to enforce the rules that do exist. Hence, these countries need to build a new institutional setting at significant cost (Peng, 2003) and face time compression diseconomies (Dierickx and Cool; 1989). The existing market substitute mechanisms in diversified business groups may provide an advantage for their affiliates when they internationalize to those settings. For instance, diversified business groups can use their internal market for talent to support the activities of their foreign affiliates. Further, given the strong sense of loyalty within diversified business groups (Guillen, 2000), they encourage the share of information and resources reducing the additional costs associated to operating abroad. Finally, diversified business groups can channel the experience gained by other affiliated firms in similar markets and provide relevant examples on how to proceed in the international arena. Taking these arguments together, we expect a positive moderating effect of business group diversification on the relationship between the aggregated measure of institutional complexity and firm performance. Hence:

Hypothesis 2: The negative relationship between aggregated institutional complexity and firm performance is positively moderated by business group diversification.

Institutional voids complexity:

Institutional voids can be defined as "situations where institutional arrangements that support markets are absent, weak, or fail to accomplish the role expected of them" (Mair and Marti, 2009:419). The nature of legal rules, the quality of enforcement of these laws (La Porta, Lopez de Silanes, Shleifer and Vishny; 1997), the role of governments and their capacity to alter the rules of the game (Delios and Henisz, 2003; Garcia Canal and Guillen, 2008; Holburn and 
Zelner, 2010) and the absence of specialized intermediaries are closely related to the level of institutional voids (i.e. Khanna and Palepu, 2000b).

Emerging countries with the largest presence of emerging market multinationals (EMMNCs) might have developed legal frames closer to the ones available in advanced economies than emerging countries with less presence of EM-MNCs. In fact, the rapid internationalization of emerging market firms has been explained by the home country's adoption of pro-market structural reforms (i.e. Cuervo-Cazurra, 2007; Cuervo-Cazurra and Dao, 2009a; Dunning, Kim and Park, 2008). In that sense, for EM-MNCs going abroad to advanced countries might have associated a lower degree of added institutional voids complexity. However, when these firms internationalize to other emerging environments or to least developed countries, firms may encounter countries in the middle of an institutional transition (Peng, 2003) that are characterized by long periods of uncertainty (Peng, 2003; Peng et al., 2005). Alternatively, these EM-MNCs may encounter countries with poor regulations, weak enforcement and the absence of specialized intermediaries. These types of countries add considerable complexity to the management of operations.

EM-MNCs associated with diversified business groups may be in a position to exploit their market-substitutes mechanisms available at home to deal with the additional costs associated with institutional voids complexity. For instance, La Porta et al (1997) argued that in the presence of poor regulations and weak enforcement, firms will have problems obtaining external funding. EM-MNCs affiliated to diversified business groups that internationalize to those settings may capitalize on their internal capital markets to fund projects abroad. Moreover, EM-MNCs might have a better understanding of weak legal institutional environments as a result of their previous exposure at home (Cuervo-Cazurra and Genc; 2008; Holburn and Zelner, 
2010), minimizing the uncertainty and managerial and coordination challenges associated with internationalization. Finally, firms from relative weak institutional environments are accustomed to participate in political processes and hence, they have higher chances to develop superior capabilities to deal with relevant actors (Cuervo Cazurra and Genc, 2008; Holburn and Zelner; 2010). In fact, given the constant interaction among units, the strong group identity among business group affiliated firms and the nature of the information flows, diversified business groups might have higher capacity to identify the best actors to lobby abroad securing favorable conditions in international markets. Therefore, given the capacity of diversified business groups to leverage abroad their non-market resources on this dimension of institutional complexity, we expect a positive impact of business group diversification on the relationship between institutional voids complexity and firm performance.

Hypothesis 3: The negative relationship between institutional voids complexity and firm performance is positively moderated by business group diversification.

Societal complexity:

According to Tihanyi et al. (2005), the main features of a particular society, its prevalent norms and values can be described by its culture. Cultural attitudes of one country cannot be characterized as better or worse than another; they only can be considered different (CuervoCazurra and Genc, 2011). The societal complexity across countries can be explained by the lack of understanding of cultural systems and the differences across them (Tihanyi et al., 2005). This lack of understanding may not only increase intra-organizational conflicts between the home country and foreign subsidiaries (Luo and Peng, 1999) but also enhance the uncertainty regarding the development and implementation of efficient strategies in foreign markets (Shane et al., 1995). 
For this dimension of environmental complexity, non-market resources have little value. Neither the market substitute mechanisms nor the political capabilities available to the core entity of the diversified business group are suitable to deal with the lack of understanding of dominant social norms in other countries. Cuervo-Cazurra and Genc (2011) argued that this dimension behaves as the psychic distance concept explained in the Upssala model (Johansson and Valhne; 1977). To minimize the negative effects associated to lack of understanding of social norms and the operating mechanisms in foreign countries, previous direct experience is required (Johansson and Valhne, 1977; 1990).

However, Guillen $(2002 ; 2003)$ argued that firms may learn from the experience of other firms, especially under conditions of uncertainty. Given that not only the strong group identity within business groups favors information sharing and organizational learning but also that internationalization entails high levels of uncertainty (Guillen, 2002), business group affiliated firms may profit from the previous international experience of other affiliated firms in the same or similar types of countries. In fact, members of a group may share information about not only the existing potential for new entrants but also suitable strategies to pursue in the market (Guillen, 2002; 2003). By providing this type of information, business group diversification increases the capacity to understand appropriate responses in foreign countries and increase the capacity of their affiliates to gain legitimacy abroad. Therefore:

Hypothesis 4: The negative relationship between societal complexity and firm performance is positively moderated by business group diversification.

Institutional voids vs. societal complexity:

Business group diversification has different capacities to deal with each of the above specific dimensions of institutional complexity. Regarding institutional voids complexity, 
business group diversification may rely on arguments related to the economic and sociological perspective. On the one side, diversified business groups have the ability to leverage their available non-market resources abroad. In the presence of institutional voids, the level of complexity escalates. In this situation, they can use both their market substitute mechanism and their political capabilities available in their core entity to minimize the additional costs and uncertainty of their foreign affiliates. On the other side, diversified business groups have strong motivations to exchange information and promote learning across units because of their strong sense of group identity (Granovetter, 2005).

On the contrary, facing societal complexity, the value of the non-market resources available in the core entity is fairly reduced. The only benefit that diversified business groups can provide to ameliorate the negative impact of societal complexity is their previous experience in the same or similar countries. Business group affiliated firms may share information with other members of the same group about suitable strategies to pursue and the appropriate rule of behavior in a particular foreign market (Guillen, 2002; 2003). Given these reasons we expect:

Hypothesis 5: The moderating effect of business group diversification is stronger on the relationship between institutional voids complexity and firm performance than on the corresponding relationship associated with societal complexity.

\section{METHODS}

Following Aulakh, Kotabe and Teegen (2000), we select three major countries within Latin America as the focus of our study: Chile, Brazil and Mexico. To select our sample, we used two sources: the 2008 ranking of the 500 largest companies in Latin America provided by America Economia magazine and firms that are publicly traded in the NYSE. However, the ranking included the largest firms in the region considering both companies headquartered in 
Latin America as well as outside the region (i.e. Walmart Mexico). Given that we are interested in Latin American firms, we used the corporate affiliations database compiled by Lexis Nexis Business Data Group to identify subsidiaries of non-Latin American firms. These firms were eliminated from the data. Next, companies from banking and financial service sectors were excluded from the sample because they do not have comparable performance measures (Ruigrok et al., 2007).

We considered the time span from 2000 to 2007 for the following reasons: First, Latin American firms started the internationalization process fairly late and took a long time to become MNEs (Cuervo-Cazurra, 2008). Indeed, Latin American countries have evolved from import substitution models characterized by centralized governments, control mechanisms and a lack of competition to liberalization models, where governments compete to attract FDI and to encourage competition. On the other side, availability of information (especially information related to internationalization of the firm) prevents the use of a longer time frame. Finally, we excluded firms with less than 3 years of data. As a result, our final sample covered 62 companies (25 Brazilian, 13 Chilean and 24 Mexican) over the period 2000 to 2007. A total of 422 firmyear observations were analyzed.

Variables

Dependent variable. We use return on assets (ROA) as a proxy of performance. ROA is one of the most commonly employed measures in the international business and strategy literatures (Daniels and Bracker, 1989; Gomes and Ramaswamy, 1999; Haar, 1989; Kim, Hoskisson and Wan, 2004). We disregard the use of ROE because it is more sensitive to capital structure measures (Hitt et al., 1997). We obtained the required financial information to calculate ROA from annual reports or SEC files. 
Independent variables: The main independent variable is environmental complexity. Environmental complexity at the MNE level can be understood as both the number of environments in which the firm participates and the heterogeneity of particular dimensions of these institutional environments (Kostova and Zaheer, 1999). Accordingly, to capture this construct, we use two types of measures: the total number of countries in which the focal firm participates (Aggregated Complexity) and the coefficient of variation associated with two institutional dimensions (Institutional Voids and Societal). Wiersema and Bantel (1992) mentioned that the coefficient of variation is the preferred method to calculate heterogeneity. To compute the coefficient of variation, we first calculate the absolute distance in the institutional dimension of interest between the home country and all the host countries in which the focal MNE has subsidiaries. Second, we calculate the standard deviation of those differences in each year. Finally, we divide the standard deviation by the mean of those distances.

To capture our measure of institutional voids complexity, we use the Economic Freedom of the World (EFW) index from the Fraser institute to calculate the coefficient of variation. The EFW index measures the extent to which the government protects not only the right of its individuals to conduct free and voluntary transactions but also associated property from the aggression of others (Gwartney, Lawson and Hall, 2011). Finally, to capture societal complexity, we use Hofstede's cultural value classification. We use Hofstede classification because it is not only considered as one of the most influential ones but also it has the greatest impact (Kirkman, Lowe and Gibson; 2006). To calculate societal complexity, we use the aggregate measure of cultural distance developed by Kogut and Singh (1988). To minimize problems of multicollinearity, we mean centered the resulting variables (Aiken and West; 1991). 
To estimate the moderating effects we need to calculate the level of business group diversification. To capture business group diversification, we need first to identify the business groups' affiliated firms. To identify business groups in each country, we used several sources. For Brazil, we used the ranking of "the 100 maiores grupos" (the 100 biggest groups) published in 2009 by Exame Magazine (containing information of 2008). In this ranking, Exame provided a list of the main controlled companies associated with each of the groups identified. For Chile, we used the report "principales grupos empresariales Chilenos" (main Chilean Business Groups) published by Universidad del Desarrollo in 2008. We directly contacted Patricio Cortes, one of the leading authors of this report, who provided the names of the major companies associated with the 33 biggest business groups in Chile. Next, we obtained the annual reports of these major firms and identified the subsidiaries related to these companies. For Mexico, we used the ranking of "the 100 empresarios mas importantes del 2008" (The 100 most important businessmen of 2008) published by Expansion Magazine. This ranking provided the name of the major companies associated with each businessman in Mexico. Next, we obtained the annual reports of these major firms and identified the subsidiaries related to these companies.

To capture group diversification, we followed the approach of Khanna and Palepu (2000a, 2000b) by considering the number of industries in which the business group affiliates participate. To determine the number of industries, we identified the industries in which each member of a particular group is involved (whether included or not in our sample) using the 2 digit SIC codes obtained from Compustat, Mergent or the company profiles provided by Lexis Nexis Business Data Group. When necessary, missing SIC codes were added by matching company product descriptions with the applicable SIC code. The resulting variable was mean centered to minimize problems of multicollinearity (Aiken and West; 1991). We recognize that 
entropy or Herfindahl measures are more accurate to portray the extent of product diversification of firms. However, unavailability of segment data prevents the accurate construction of such measures. Therefore, our measure of business group diversification (BG diversification) is the count of industries in which the group participates. This is a time invariant variable captured in 2008.

Model Specification

To test the hypotheses developed in this paper, we used panel data. With panel data, pooled OLS regression is not appropriate (Baum, 2006). The assumptions of normality, homoscedastic variance across occasions and individuals, and independent and identically distributed errors do not hold in longitudinal studies (Singer and Willet, 2003). To deal with these problems, we used panel data models. To decide whether we would use random or fixed effects, we conducted the Hausman Test that examined the hypothesis that the error term of the random effects model is not correlated with the regressors (Baum, 2006; Wooldridge, 2002). Our results rejected this hypothesis, favoring the use of fixed effects models.

Control variables. Following previous research, we control for company size (total assets) company age (number of years from inception) and degree of internationalization (foreign sales to total sales). To control for multicollinearity we mean centered degree of internationalization and company age. All time invariant effects are controlled by this statistical model.

\section{RESULTS}

The final sample consists of 422 firm-year observations from 62 firms giving an average of 6.8 years of data per company. As a consequence, we are dealing with an unbalanced dataset. The fixed effect model described above helps address this problem. Table 4 presents the descriptive statistics and the correlation matrix for the variables of interest. To check for 
potential problems associated with multicollinearity, we analyze Variance Inflation Factors (VIF). The mean VIF reported was 2.81 and all scores are less than 2.9, considerably lower than the standard cut off point of 10 (Hair, Anderson, Tatham, and Black, 1998). As reported by the non-transformed variables, not only do the Latin American multinationals included in the sample tend to be fairly old (48 years old) and large (6,635 US\$M), but also they are at early stages of the internationalization process.

Table 5 presents the results of the fixed effects models used to test the hypothesized relations. It is important to notice that panel data models report three R-squares, of which interpretation varies depending on the type of model used. The relevant R-square for fixed effects models is the R-square within (StataCorp, 2005).

Hypothesis 1 predicted a negative effect of institutional complexity on firm performance in the context of Latin American multinationals. Our empirical evidence provides marginal support for this hypothesis. To capture institutional complexity, we used three indicators, the number of countries in which the focal firm has established operating subsidiaries, the coefficients of variation associated with institutional voids and societal complexity. The number of countries has the hypothesized sign and reaches significance in all the models analyzed $(\mathrm{p}<0.1)$. Institutional voids complexity has the hypothesized sign in all the models analyzed. However, it fails to reach significance when we examine its main effect on firm performance (model 2). Once the interaction is included, institutional voids complexity becomes significant $(p<0.05)$. Finally, societal complexity fails to reach significance in all the models analyzed. Overall, we considered that our base hypothesis was partially supported.

Our second hypothesis predicted a positive moderation of business group diversification on the relationship between the aggregated measure of complexity and firm performance. 
Table 4: Descriptive statistics and correlations for variables included in essay 2

\begin{tabular}{|c|c|c|c|c|c|c|c|c|c|c|c|c|c|}
\hline & OBS & MEAN & S.D. & MIN & MAX & VIF & 1 & 2 & 3 & 4 & 5 & 6 & 7 \\
\hline 1. $\mathrm{ROA}$ & 422 & 0.058 & 0.07 & -0.23 & 0.30 & & 1 & & & & & & \\
\hline 2. SIZE & 422 & 8099 & 31517 & 204 & 563468 & 1.01 & -0.05 & 1 & & & & & \\
\hline $\begin{array}{l}\text { 3. AGE } \\
\text { 4. Degree of }\end{array}$ & 422 & 0.24 & 2.24 & -3.50 & 3.50 & 1.18 & 0.26 & 0.00 & 1 & & & & \\
\hline Internationalization (FSTS) & 422 & 0.00 & 0.07 & -0.32 & 0.61 & 1.17 & 0.06 & 0.01 & 0.20 & 1 & & & \\
\hline $\begin{array}{l}\text { 5. Aggregated Complexity } \\
\text { 6. Institutional voids }\end{array}$ & 422 & 0.00 & 1.66 & -8.63 & 11.38 & 1.30 & 0.03 & 0.09 & 0.35 & 0.36 & 1 & & \\
\hline Complexity & 422 & 0.00 & 0.16 & -0.68 & 0.44 & 1.33 & 0.01 & 0.02 & 0.17 & 0.11 & 0.15 & 1 & \\
\hline 7. Cultural Complexity & 422 & 0.00 & 0.10 & -0.67 & 0.40 & 1.26 & 0.06 & 0.05 & 0.23 & 0.20 & 0.24 & 0.45 & 1 \\
\hline
\end{tabular}

MEAN VIF 1.21 
Table 5: The impact of complexity and proposed moderating effects on firm performance.

\begin{tabular}{|c|c|c|c|c|c|c|}
\hline Variables & Model 1 & Model 2 & Model 3 & Model 4 & Model 5 & Model 6 \\
\hline \multirow[t]{2}{*}{ Constant } & $0.0521 * *$ & $0.0559^{* *}$ & $0.0561 * *$ & $0.0560 * *$ & $0.0559 * *$ & $0.0561 * *$ \\
\hline & 0.0020 & 0.0022 & 0.0022 & 0.0022 & 0.0022 & 0.0022 \\
\hline \multirow[t]{2}{*}{ SIZE } & 0.0000 & 0.0000 & 0.0000 & 0.0000 & 0.0000 & 0.0000 \\
\hline & 0.0000 & 0.0000 & 0.0000 & 0.0000 & 0.0000 & 0.0000 \\
\hline \multirow[t]{2}{*}{ AGE } & $0.0071^{* *}$ & $0.0076^{* *}$ & $0.0075^{* *}$ & $0.0073 * *$ & $0.0076^{* *}$ & $0.0076^{* *}$ \\
\hline & 0.0009 & 0.0010 & 0.0010 & 0.0010 & 0.0011 & 0.0011 \\
\hline \multirow[t]{2}{*}{ Deg. of internationalization } & -0.0072 & 0.0387 & 0.0395 & 0.0377 & 0.0390 & 0.0339 \\
\hline & 0.0280 & 0.0307 & 0.0305 & 0.0304 & 0.0308 & 0.0305 \\
\hline \multirow[t]{2}{*}{ Aggregated Complexity } & & $-0.0027+$ & $-0.0056^{* *}$ & $-0.0028+$ & $-0.0027+$ & $-0.0049^{*}$ \\
\hline & & 0.0015 & 0.0019 & 0.0014 & 0.0015 & 0.0020 \\
\hline \multirow{2}{*}{\multicolumn{2}{|c|}{ Institutional voids Complexity }} & -0.0188 & -0.0225 & $-0.0339 *$ & -0.0190 & $-0.0332 *$ \\
\hline & & 0.0142 & 0.0142 & 0.0154 & 0.0145 & 0.0153 \\
\hline \multirow[t]{2}{*}{ Societal Complexity } & & 0.0108 & 0.0159 & 0.0116 & 0.0106 & 0.0182 \\
\hline & & 0.0230 & 0.0230 & 0.0228 & 0.0231 & 0.0230 \\
\hline Aggregate complexity* & & & $0.0008^{*}$ & & & $0.0006+$ \\
\hline BG diversification & & & 0.0004 & & & 0.0004 \\
\hline institutional voids complexity & & & & $0.0053 *$ & & $0.0054 *$ \\
\hline BG diversification & & & & 0.0021 & & 0.0025 \\
\hline Societal complexity* & & & & & 0.0004 & -0.0059 \\
\hline BG diversification & & & & & 0.0039 & 0.0043 \\
\hline R-sq within & 0.0966 & 0.1418 & 0.1543 & 0.1568 & 0.1418 & 0.1663 \\
\hline R-sq between & 0.0046 & 0.0150 & 0.0271 & 0.0126 & 0.0149 & 0.0235 \\
\hline R-sq overall & 0.0504 & 0.0678 & 0.0749 & 0.0734 & 0.0678 & 0.0801 \\
\hline Number of observations & 739 & 422 & 422 & 422 & 422 & 422 \\
\hline Number of firms & 98 & 62 & 62 & 62 & 62 & 62 \\
\hline
\end{tabular}

$+\mathrm{p}<0.10 ;{ }^{*} \mathrm{p}<0.05 ;{ }^{* *} \mathrm{p}<0.01$

We test this hypothesis in model 3 and 6 in table 5. We found a positive moderating effect in both models. Although, the results are weakened in model 6, the results remain statistically significant $(\mathrm{p}<0.10)$. Hence, our second hypothesis is supported.

Our third hypothesis predicts a positive impact of business group diversification on the relationship between institutional voids complexity on firm performance. We test these hypotheses in models 4 and 6 .We found a positive moderating effect $(\mathrm{p}<0.05)$ in both models. 
Further, in the presence of this interacting term, the moderating effect on the relationship associated with the aggregated measure weakens. Hence, our third hypothesis was supported.

Our fourth hypothesis argued in favor of a positive effect of business group diversification on the relationship between societal complexity and firm performance. However, our empirical evidence does not support this hypothesis. Neither the main effect of societal complexity nor its interacting terms (models 5 and 6) reach significant levels. Hence, this hypothesis was not supported.

Our last hypothesis argued in favor of a stronger moderating effect of business group diversification on the relation between institutional voids complexity and firm performance. Considering the lack of significant results associated with societal complexity and the strong moderating effect related to the institutional voids complexity, our last hypothesis was supported.

Overall, we found support for three hypotheses and partial support for another one. Further, we did not find support for our fourth hypothesis.

\section{DISCUSSION}

Given the institutional transition in which emerging markets are immersed (Peng, 2003), we recognize the need to better understand the capacity of business groups to generate value for their firm affiliates. Rather than analyzing their re-focusing of activities as a response to environmental changes, we explore an alternative avenue that these organizational forms have to distribute their large overhead. In particular, we examine the extent to which business group diversification has the capacity to ameliorate the negative effects of environmental complexity on firm performance.

Delving more deeply into our individual results, the overall main effect of environmental complexity on firm performance was captured by three measures: the number of countries in 
which the focal MNE participates and both the institutional voids and the cultural coefficients of variation associated with those countries. While we found partial support for the aggregated measure of complexity (number of countries in which the focal firm participates), we failed to find statistical evidence for the other two measures. This provides partial support for our first hypothesis. We believe that the overall measure of complexity provides evidence for the argument that environmental complexity increases both the costs of internationalization of EMMNCs and the challenges of those firms to gain and maintain legitimacy.

However, the lack of empirical support for the institutional voids and societal complexity measures is somehow surprising. In the case of the institutional voids coefficient of variation, we found that in the presence of the interacting term, this variation index reached the hypothesized sign and becomes significant. This might be an indication of the importance of relevant moderators to uncover the relation of this type of complexity on firm performance. In the case of the effect of societal complexity, we fail to find statistical support in all our models. This lack of findings is in line with the ones found in the meta-analysis of Tihanyi et al. (2005) on the impact of cultural distance. Since our measure of societal complexity is based on this construct, it is relevant to explore some reasons why cultural distance has little empirical impact on important dependent variables such as entry mode decisions, internationalization and firm performance. One line of criticism is related to the concept of culture and the measurement of cultural distance. Shenkar, Luo and Yeheskel (2008) argued that culture is a construct difficult to measure because of its intangibility and intricacy. Shenkar (2001) argued that establishing distances across cultures is even more problematic. Given the multifaceted nature of the phenomena, it is difficult to capture the relevant dimensions in which two countries differ in one measure (Tihanyi et al., 2005). Further, Shenkar (2001) mentioned that the cultural distance 
construct has serious limitations that undermine its validity. A second line of criticism is related to the potential direct effect of cultural distance on firm performance. Tihanyi et al. (2005) suggested that it might be that cultural distance does not have a direct effect on either strategic decision making processes or on firm performance. Both lines of criticisms may explain the lack of findings associated with societal complexity.

Our second finding suggests that business group diversification effectively moderates the relationship between our aggregated measure of complexity and firm performance. In fact, we found that business group diversification ameliorates the negative effect of environmental complexity. Several mechanisms may explain such impact. For instance, the previous experience in the same or similar markets of other business affiliated firms may help the focal firm to minimize the uncertainty in those foreign countries. Alternatively, the core entity of the diversified business group might use its non-market resources to benefit the internationalization process of their affiliates. Since it is in the core entity where the administrative and financial control of the resources available in the diversified business group resides, business groups might deploy such resources to their affiliates in the case of need. Among these resources are the market substitute mechanisms and the political capabilities developed in the home country.

To clarify the effect of business group diversification and the relative importance of their different available mechanisms, we assess its impact on two dimensions of environmental complexity. We found empirical evidence that business group diversification moderates the relationship between institutional voids complexity and firm performance, but we failed to find any moderation effect on the corresponding relationship associated with societal complexity. Further, the empirical results suggest that the effect of diversified business groups is stronger in the case of institutional voids complexity. While our measure of societal complexity has several 
limitations that may account for the lack of findings, we believe that since institutional voids complexity is more related to the existence of institutional voids in host countries, diversified business groups are in position to use their non-market resources available in their core entity.

Diversified business groups developed at home those non-market resources that help their affiliates to respond more efficiently in the face of uncertainty, political risks or corruption (Cuervo-Cazurra, 2006; Holbrun and Zelner, 2010). For instance, diversified business groups may use their market substitute mechanisms to obtain scarce resources in host countries. Further, their understanding of weak institutional environments as a result of their previous experience at home may help business group affiliated firms not only to minimize the managerial and coordination challenges related to the internationalization process but also to increase their understanding of the rules to compete in different host countries and therefore, enhance their legitimacy. In contrast, to deal with societal complexity, diversified business groups do not have non-market resources to rely on. The only advantage that affiliated firms may have is the previous experience of other affiliated firms in the same or similar markets. However, given that emerging multinationals from Latin America are at early stages of internationalization (ECLAC, 2005), the accumulated foreign experience within groups is limited and hence, its impact may be negligible.

At the beginning of this manuscript, we mentioned that despite business groups facing strong pressures to refocus their operations; they have the alternative to distribute their large overhead by exploring (through their affiliated firms) international markets. We found evidence of their capacity to reduce the negative effects of environmental complexity on firm performance. In particular, this capacity is stronger when diversified business groups have the 
chance of using their non-market resources to deal with the additional institutional complexity resulting from the internationalization process.

\section{LIMITATIONS AND DIRECTIONS FOR FUTURE RESEARCH}

This research is not without limitations. Given that we draw our sample from the largest firms within the region, the impact of diversified business groups cannot be generalized to smaller firms even within Latin America. In fact, previous research suggests that the effect of business group affiliation is not universal across their affiliates. For instance, Kim, Hoskisson and Wan (2004) argued that the benefits of business groups are not homogeneous and depend on the power of their affiliated firms within the network. Further, Carney et al. (2011) mentioned that some group members benefit from their affiliation at the expense of others. Hence, the impact of diversified business groups on smaller firms may be an interesting avenue for future research.

Our results need to be interpreted with caution. First, we relied on three different publications with different methodologies to define business group diversification across our three country locations. While we took efforts to ensure consistency across the samples, this may nonetheless affect the reliability and comparability of the information collected. Second, to capture diversification and group membership, we used only a count measure of SIC codes and dummy variables similar to the one used by Khanna and Palepu (2000a, 2000b). Since it was not possible to determine the level of sales per each SIC code, our measure may have low construct validity due to problems of deficiency and contamination. Information about Latin American firms is fragmented and incomplete. Therefore, our capacity to build adequate measures of product diversification remains fairly restrictive. Future research should account for those limitations. 
Verbeke, Li and Goerzen (2009) argued that the failure to recognize both organizational and environmental complexity may obscure a clear understanding of the impact of internationalization on firm performance. In this article, we explore the impact of environmental complexity on firm performance and how diversified business groups moderate that relation. Nevertheless, this article does not examine the impact of organizational complexity. Future research may explore how organizational complexity impacts firm performance and whether and how diversified business groups help to deal with this complexity.

We use the concept of cultural distance to capture societal complexity. As mentioned, the concept of cultural distance has conceptual and methodological problems (Shenkar, 2001). Alternatively, we may use other measures to capture cultural differences between countries. For instance, Luo and Shenkar (2011) develop a measure of cultural friction that incorporates both country and organizational level factors that aims to measure the effect of cultural differences associated with international transactions. Given our data limitations highlighted above, this also remains a potential for future research.

Finally, given the need to build location bound investments in particular host countries to exploit their firm specific assets (Rugman and Verbeke, 2004; 2005; 2007), future research might explore whether the impact of diversified business groups varies depending upon the region in which their activities are concentrated. Alternatively, the nature of the non-market resources possessed by diversified business groups seems to be more important in less institutionally developed countries than in more institutionally developed ones. Exploring these potential differences associated with the region of investment and the stage of development of host countries is an interesting avenue for future research. 
Peng et al. (2005) mentioned that there is some evidence suggesting that in the presence of institutional transitions, diversified business groups may expand the scope of operations rather than refocusing their activities. In this article, we found that in the presence of institutional changes, diversified business groups have alternative routes to distribute their large fixed costs. In particular, we found that business group diversification has the capacity to ameliorate the negative effects of the environmental complexity associated with the internationalization of their affiliates. 


\section{CHAPTER 4}

\section{THE IMPACT OF BUSINESS GROUP DIVERSIFICATION ON EMERGING MARKET}

\section{MULTINATIONALS: EVIDENCE FROM LATIN AMERICA.}

Diversified business groups represent the most efficient organizational form to conduct transactions in the presence of large institutional voids because they reduce transaction costs by internalizing activities. (Khanna and Palepu, 1999; Khanna and Palepu, 2000b). However, emerging economies are characterized by a reduction of government intervention and by the improvement of governance mechanisms (Cuervo-Cazurra and Dau, 2009a; 2009b). The adoption of pro-market mechanisms aims to improve the functioning of emerging economies by reducing government participation, optimizing resource allocation, enhancing firm efficiency and minimizing both transaction and agency costs (Cuervo-Cazurra and Dau, 2009a; 2009b).

Under the adoption of market oriented institutions, the organizational costs of diversified business groups may be higher than their benefits, and hence, these business groups face pressures to refocus their operations (i.e. Chakrabarti, Vidal and Mitchell, 2011; Hoskisson, Johnson, Tihanyi and White, 2005). Nevertheless, given that the majority of business groups are old and large; they also face strong inertial processes that constrain their capability to adapt to these environmental changes (Baum and Shipilov, 2006; Hannan and Freeman, 1984).

Given these conflicting pressures, diversified business groups may pursue other alternatives to distribute their large overhead. While the opportunities at home to further diversify are fairly restrictive, diversified business groups can encourage their affiliates to internationalize. Previous research at the firm level suggests that the non-market resources possessed by diversified business groups may have a positive impact on the internationalization of their affiliates (i.e. Holburn, 2001; Holburn and Zelner; 2010). In this article we explore this 
alternative avenue. Further, considering that even non location bound firm specific assets tend to be regionally bound (Rugman and Verbeke, 2004) and that the benefits of business group diversification are associated with the presence of institutional voids (i.e. Khanna and Palepu, 1997, 1999, 2000a, 2000b), we explore the impact of business group diversification on the relationship between scope of internationalization and firm performance of their affiliates and how this impact varies depending on whether their affiliates expand to more or less developed countries and on whether their affiliates are regionally or globally oriented.

We explore these relations in the context of Latin America. Latin America has been characterized not only by the large presence of family business groups (Guillen, 2000, Vassolo, De Castro and Gomez Mejia; 2011) but also by the adoption of extensive structural reforms at almost the same time (Brenes, 2000; Brenes and Dominguez, 1997; Cuervo-Cazurra; 2007). Further, the presence of emerging multinationals from the region will increase rapidly in the following years (i.e. WIR, 2010). For these reasons we believe that Latin America represents an ideal setting for our analysis.

This paper proceeds as follows: first, we review the literature related to emerging markets, internationalization and diversified business groups. Second, we develop a set of testable hypotheses. Next, we will present our methodology and results. Finally, we discuss the findings, contributions and limitations of our paper.

\section{LITERATURE REVIEW}

\section{Emerging Economies}

Emerging economies are countries that "satisf(y) two criteria: a rapid pace of development and government policies favoring economic liberalization and the adoption of a free market system" (Hoskisson, Eden, Lau and Wright; 2000: 249). Accordingly, emerging 
economies are characterized by a reduction of government intervention and by the improvement of governance mechanisms (Cuervo-Cazurra and Dau, 2009a; 2009b; Williamson, 2004).

On the one side, economic liberalization, or the reduction of government intervention in the economy, favors efficiency in emerging economies. Firms have more freedom to take optimal decisions about resource allocation and have better access to high quality resources. Further, economic liberalization has a positive impact on the level of domestic competition by lowering tariffs and barriers to new industry entrants forcing efficiency gains among existing participants (Cuervo-Cazurra, 2007; Cuervo-Cazurra and Dau, 2009a; Diaz Hermelo and Vassolo, 2010; Thomas and D'Aveni, 2010).

On the other side, the improvement of governance mechanisms favors the reduction of transaction costs. Better governance mechanisms involve changing existing regulations, a better implementation of the rules created, and a favorable evolution of the monitoring and enforcement procedures available for conflict resolution (Cuervo-Cazurra and Dau, 2009a). Also, improvements in governance constrain the discretion of public officials and hence, limit the room for government agents to demand bribes from market participants (Shleifer and Vishny; 1997).

Further, Cuervo-Cazurra and Dau (2009b) argued that the implementation of pro market reforms also reduce agency costs by aligning the objectives of agents and principals without changes in ownership. Cuervo-Cazurra and Dau (2009b) argued that these reforms reduce managerial misbehavior and curb potential opportunism by improving monitoring mechanisms and by providing correcting instruments in labor, capital and product markets.

Despite these claimed benefits, Peng, Lee and Wang (2005) argued that the adoption of market reforms by emerging economies is uncertain in the short run and that these countries can 
be considered as half reformed economies. In fact, Peng (2003) argued that emerging economies are in the middle of an "institutional transition" (Peng, 2003: 275) that may involve long periods of time and uncertainty.

North (1990) argued that while some formal rules may change relatively rapidly; informal rules are difficult to modify and tend to remain stable over time. Nevertheless, even the adoption of formal market reforms may also require long periods of time. For instance, Peng (2003) proposed that the adoption of formal market reforms requires emerging economies to develop relevant institutions. Emerging economies lack both enough rules to govern market transactions and credible mechanisms to enforce the rules that do exist. Hence, these countries need to build a new institutional setting at significant cost (Peng, 2003) facing time compression diseconomies (Dierickx and Cool, 1989). Further, Hoskisson et al. (2000) argued that the development of legal infrastructure in emerging economies has been difficult to achieve. The lack of development of the legal infrastructure affects not only the ability to enforce contracts (Estrin and Wright, 1999) but also increases the predominance of corruption (Nelson, Tilley and Walker, 1998).

In summary, while most emerging economies are implementing structural reforms (Peng, Lee and Wang, 2005), firms in those environments still face large institutional voids and uncertainty about the possible evolution of these institutional changes (Peng, 2003). Internationalization, Scope and Firm performance

To reconcile previous inconsistent empirical results between internationalization and performance, Contractor, Kundu and Hsu (2003) proposed a general s-curve theory of international expansion. At early stages of internationalization, multinationality has a negative effect on firm performance. Later, firms started to profit from their foreign involvement. The claimed benefits of internationalization are realized during this stage. Finally, few firms over- 
internationalize. At this point, the marginal costs exceed the marginal benefits of further internationalization, and hence, its impact on performance is negative again. Since the length of the second stage is larger than the other two, Contractor (2007) argued that internationalization is generally good for companies.

While the s-curve theory of internationalization is gaining consensus (Glaum and Oesterle, 2007), a recent stream of research suggests that attempts to developed a general theory of internationalization are inadequate (i.e. Hennart, 2007; 2011; Verbeke, Li, Goerzen; 2009). For instance, in their meta-analysis, Bausch and Krist (2007) argued that international business researchers should avoid looking for general theories of the M-P relationship. Instead, they suggest the introduction of fine grained moderators to better understand the nature of the relationship. Given the predominance of diversified business groups in emerging markets (Khanna and Palepu, 1997; 1999), their different mechanisms to generate value and the pressures that they face to distribute their large overhead given the recent institutional changes (Hoskisson et al., 2004; Hoskisson et al., 2005), we believe that the introduction business group diversification can add to our understanding of the M-P relationship in emerging markets.

Further, Vermeulen and Barkema (2002) mentioned that the size and scope of internationalization represent different dimensions of multinationality. While the size of international operations may positively affect firm performance (Vermeulen and Barkema 2002), the impact of the scope of operations tends to be negative. Vermeulen and Barkema (2002) argued that to have operations in multiple countries in a short period of time exceeds the absorptive capacity of the focal MNE and hence, negatively impacts firm performance. Given that emerging market firms can be considered latecomers in the international market place (Bonaglia, Goldstein, Mathews, 2007), they need to internationalize rapidly (Mathews, 2006) in 
terms of entry mode decisions and location choices (Luo and Tung, 2007), reinforcing this negative effect. Moreover, to have operations in multiple markets increases the complexity of operations not only because firms need to understand how to manage their facilities in different institutional environments (Kostova and Zaheer 1999; Vermeulen and Barkema, 2002) but also because they need to adjust accordingly their operations and "dominant logic" (Prahalad and Bettis, 1986) within the firm. A higher level of complexity represents higher costs for MNCs (Goerzen and Beamish, 2003; Verbeke, Li and Goerzen, 2009), affects their capacity to establish and maintain legitimacy (Kostova and Zaheer, 1999) and increases their uncertainty by operating in different markets (Tihanyi, Griffith and Russell, 2005).

Finally, Rugman and Verbeke (2004) proposed that the lack of consistent results in previous literature may be explained by considering the host locations in which the focal firm internationalized. They argued that multinationals possessed a set of non-location bound firm specific assets (FSA) that can be transferred to different locations at relatively low cost (Rugman, Verbeke and Nguyen, 2011). However, to be exploited abroad, even these FSAs must be complemented by host-country location-bound investments (Rugman and Verbeke, 2005; 2007; 2008b). The capacity to exploit these non-location bound FSA abroad is dictated by the level of the required complementary investments and by the risks assumed by the focal MNE in those particular locations (Rugman and Verbeke, 2008b).

Given the process of institutional convergence within regions, Rugman and Verbeke (2007) argued that intra-regional distance is decreasing and inter regional distance is increasing. Hence, when the focal MNE internationalizes outside its home-region, the liabilities of foreignness are greater; the required complementary investments escalate and the risks assumed increase dramatically (Rugman and Verbeke, 2004; 2008a; 2008b). However, while Rugman and 
Verbeke $(2004 ; 2008 \mathrm{a} ; 2008 \mathrm{~b})$ relate these non-location bound FSA with upstream or downstream activities of the value chain, Johansson and Valhne (2009) stress the importance of being part of relevant networks in host countries. In this sense, political capabilities, or the ability to identify relevant stakeholders ex ante (Holburn and Zelner; 2010), may represent an important firm specific asset to minimize the "liabilities of outsidership" (Johansson and Valhne, 2009: 1411) or the negative effect of being an outsider on the relevant networks of the host markets in which the focal firm participates.

Business group diversification

Diversified business groups and traditional conglomerates are considered different types of organizational forms (Carney et al., 2011). According to Yiu et al. (2007), diversified business groups are characterized by the predominance of social ties to link affiliated firms, by a closely coordinated action among these firms (Chung, 2001), and by the presence of a core entity that provides administrative and financial control over the resources possessed (Yiu et al., 2007), and are responsible for managerial coordination among the business affiliated firms (Khanna and Rivkin, 2001; Yiu et al., 2007). Given its position in the diversified business group, the core entity the core entity fill what would otherwise be a "structural hole" (Burt, 1992: 2) in the organization and as such, it not only has access to better information and high quality control over the resources available in the network but also has a larger influence on other member firms (Yiu et al., 2007). Hence, the core entity acts as an intermediary among different units, providing access to certain resources (i.e. non-market resources, information, contacts) in case of need.

One of the most common arguments used to explain the existence and potential value generation of diversified business groups in particular institutional environments is the presence of institutional voids and high transaction costs (i.e. Carney et al., 2011; Khanna and Palepu, 
1997; 1999; 2000a; 2000b). In this type of environment, diversified business groups create market substitute mechanisms to minimize the existing transaction costs (Hoskisson et al., 2004; Hoskisson et al., 2005) and represent the most efficient organizational form to conduct transactions (Khanna and Palepu; 1997; 1999). Moreover, in countries with prevailing government intervention or where corruption is widespread, diversified business groups may act as rent seekers because they can use preferential access to key officials to secure favorable conditions in multiple businesses (Khanna and Palepu, 2000a). In fact, Chakrabarti et al. (2011) argued that diversified business groups obtain profits because of their preferred access to nonmarket benefits. Hence, in the presence of institutional voids, business group diversification has the capacity to generate value for their affiliates by using their non-market resources available in the core entity.

Nevertheless, the benefits associated with the internalization of transactions within the diversified business group must be compared with the organizational costs related to the maintenance of those market-substitute mechanisms used extensively by the core entity (Hoskisson et al., 2004; Hoskisson et al., 2005). According to Hoskisson et al. (2004), the adoption of pro-market reforms by emerging countries made the market substitute mechanisms of these groups unnecessary.

An alternative perspective to explain diversified business groups is given by the sociological perspective. According to Granovetter $(1994 ; 2005)$, the existence of this organizational form is not only explained by economic factors. In fact, within business groups, affiliated firms possess a sense of group identity that favors loyalty and reciprocity (Granovetter, 1994). Guillen $(2002 ; 2003)$ suggest that this sense of loyalty encourages information sharing 
and organizational learning and discourages potential disputes. Hence, internal transaction costs are minimized (Khanna and Palepu, 2000).

Carney et al. (2011) argued that both economic and sociological arguments are more relevant for domestic markets than for international settings. On the one side, the market substitutes mechanisms used to solve the institutional voids and the contacts with relevant actors may be more valuable at home than abroad (Meyer, 2006; Tan and Meyer, 2010). On the other side, as the social ties are predominant in the home market, the impact of those abroad should be limited and therefore, business group affiliated firms may have a domestic orientation (Carney et al; 2011). For instance, Hundley and Jacobson (1998) found that given the preferential treatment that business group affiliated firms received from other members of the group, they tend to be more domestically oriented.

Nevertheless, recent research suggests that non-market resources also have value outside the home markets (i.e. Cuervo-Cazurra; 2006; Cuervo-Cazurra and Genc; 2008; 2011; Henisz, 2003; Holburn, 2001; Holburn and Zelner, 2010; Garcia Canal and Guillen, 2008). For instance, Cuervo-Cazurra and Genc (2008) found that since emerging market firms have developed nonmarket resources and capabilities at home and have learned how to operate in difficult institutional environments, they have a competitive edge over developed country multinationals when they participate in less developed economies. Further, Holburn and Zelner (2010) argued that emerging market firms develop these non-market capabilities by organizational learning processes and imprinting effects that occur mainly in their home country. While this research does not directly target diversified business groups, the benefits claimed are closely related to the non-market resources possessed by these organizational forms in their core entity. 
Moreover, in the presence of uncertainty, diversified business groups may profit from their group identity, their sense of trust and their emphasis on organizational learning and information sharing. Johansson and Valhne (2009) argued that internationalization represents an uncertain process. In uncertain situations, firms tend to imitate the behavior of other organizations in their organizational fields (DiMaggio and Powell; 1983). Guillen (2002; 2003) used these arguments to suggest that not only firms may learn from the previous experience of other business group affiliated firms but also they can imitate previous strategies of other members in particular host markets to minimize risks and be perceived as a legitimate actor within the group.

\section{HYPOTHESIS DEVELOPMENT}

In this section, we use the literature review described above to derive a set of hypothesis suitable to assess the impact of business group diversification on the internationalization processes of their affiliates. In particular, we explore the capacity of diversified business groups to moderate the relationship between scope of internationalization and firm performance, and how this effect varies depending on both the level of institutional development associated with the network of countries in which the MNE participates and the region in which the focal MNE internationalizes.

The overall moderating effect of business group diversification

According to Vermeulen and Barkema (2002), the impact of the scope of international operations on firm performance tends to be negative, especially in the short run. To have presence in multiple countries increases the complexity of operations (Kostova and Zaheer, 1999) and limits the ability of MNEs to manage their internal operations. On the one side, the

absorptive capacity of the MNE is negatively affected due to the bounded rationality nature of 
their managers and time compression diseconomies (Dierickx and Cool, 1989) to absorb such new conditions (Vermeulen and Barkema, 2002). On the other side, MNEs need to adapt their dominant mindset and their internal processes to new external environments with imperfect information. As a consequence, we expect a negative impact of the scope of operations on firm performance.

However, business group diversification has several mechanisms to positively impact the internationalization of their affiliates. Considering sociological mechanisms, business group affiliated firms share a strong identity and sense of loyalty (Granovetter, 2005) that favors information sharing, learning and imitation, especially under conditions of uncertainty (Guillen, 2002). Since internationalization represents an uncertain process (Johansson and Valhne, 2009), diversified business groups through their core entity can channel previous international experiences of other affiliated firms to the focal MNE, reducing the uncertainty of foreign operations and enhancing the capacity to gain and maintain legitimacy abroad.

Considering the institutional voids mechanisms, diversified business groups might use their non-market resources developed at home to positively impact the internationalization of their affiliates. For instance, other emerging market economies are in the middle of institutional transitions (Peng, 2003) that escalates the uncertainty and complexity of operations (Peng, 2003; Peng, Lee and Wang; 2005). In this type of setting, diversified business groups may use their political capabilities developed at home to identify government officials in these host countries and obtain favorable treatment (Holburn and Zelner, 2010). Further, in developed countries, diversified business groups can use this capability to minimize the "liabilities of outsidership" (Johansson and Valhne, 2009) faced and increase profit from their international expansion. Finally, diversified business groups can use their internal market substitute mechanisms in 
capital, labor and product markets to minimize transaction costs and be profitable in foreign countries. Taking these arguments together, we expect a positive moderating effect of business group diversification on the relationship between the scope of international operations and firm performance. Hence:

H1: There is a positive moderating effect of business group diversification on the relationship between scope of operations and firm performance.

The moderating effect of business group diversification in less developed institutional environments.

The presence of institutional voids and high transaction costs is one of the most common arguments to explain the existence and the capacity to generate value of diversified business groups (i.e. Carney et al., 2011; Khanna and Palepu, 1997; 1999; 2000a; 2000b). In countries that are characterized by the presence of institutional voids, diversified business groups can use not only their market substitute mechanisms but also their political capabilities to reduce the complexity associated with the international expansion of their affiliates. This favors their internationalization process.

Emerging or least developed economies possess weak institutional environments. In this type of country, business group affiliated firms may get access to scarce resources due to their access to market substitute mechanisms. For instance, they can access financial resources or managerial talent not easily available in those settings. Further, given the underdeveloped legal infrastructure and the erratic enforcement of the laws enacted (Hoskisson et al., 2000; Vassolo et al., 2011) international investors may be reluctant to invest. However, due to their previous experience with international investors at home and their higher ability to compete in difficult institutional environments (Cuervo-Cazurra and Genc, 2008), diversified business groups may 
attract qualified foreign investors (Khanna and Palepu, 1997) to pursue international opportunities especially in other emerging or least developed countries. In that sense, business group affiliated firms may gain access to technological resources not easily available in those settings and foreign partners may perceive fewer risks assumed due to their favorable previous experience with the focal group.

Further, Holburn (2001) argued that companies with political capabilities may find it attractive to internationalize into countries characterized by high political hazards to exploit such abilities. For instance, Garcia Canal and Guillen (2008) suggest that firms might prefer to enter countries where authorities possess discretionary power to secure better conditions at entry. Finally, Holburn and Zelner (2010) argued that not all firms respond equally to political hazards. The responses to these hazards depend on the political capabilities possessed by MNCs. Given their access to political capabilities, business group affiliated firms are more willing to enter politically hazardous countries to leverage such capabilities and minimize the associated uncertainty and complexity of operations. Taking these arguments together, we expect:

H2: The impact of BG diversification on the relationship between scope of operations and firm performance is more positive for business group affiliated firms that internationalize mostly to other emerging or least developed markets.

The moderating effect of business group diversification within the home region

Despite the fact that Rugman and Verbeke (2004; 2005; 2007; 2008a; 2008b) focused on market resources to explain non-location bound FSA and their capacity to be deployable abroad, non-market resources available in the core entity of the diversified business group also represent a source of competitive advantage that is susceptible to being exploited internationally (i.e. Cuervo-Cazurra and Genc, 2008; 2011). According to Rugman and Verbeke (2004), the 
transferability of non-location bound FSA is severely constrained when the focal MNE ventures beyond its home region. MNEs that venture above and beyond their home region must severely invest in complementary location bound assets. Further, their lack of understanding of the rules to compete in those host regions affects the efficiency of those investments and hence, increases the risks assumed. For instance, Tihanyi, Griffith and Russell (2005) argued that the lack of understanding of institutional norms increases the operational challenges faced by the MNE.

When business group affiliated firms internationalize within their home region, they can use their previous experience at home to leverage their market substitute mechanisms available in the core entity. According to Vassolo, De Castro and Gomez-Mejia (2011), Latin America can be considered a relatively homogeneous region with a common dominant religion, legal structure and language. Even the difference between Portuguese and Spanish does not prevent communication flows among Latin countries (Vassolo et al., 2011). Within the region, the market substitute mechanisms available within the diversified business groups can be deployed abroad without the need of considerable investment on location bound FSA. For instance, most Latin American countries can be considered as environments with relatively weak investor protection (La Porta et al.,1997). In this type of environment, firms will have problems obtaining external funding (La Porta et al.,1997). Latin American MNCs affiliated with diversified business groups that internationalize to other countries within the region may capitalize on their internal capital markets and fund projects abroad. Further, business group affiliated firms may use their internal markets for managerial talent to start new ventures within the region. Vassolo, De Castro and Gomez-Mejia (2011) mentioned that the informal sector represents more than $50 \%$ of all employees in Latin America. Managers selected and trained in the home country and 
transferred to other countries within the region are more flexible to negotiate with third parties using non-contractual mechanisms (De Soto, 2000).

Moreover, business group affiliated firms that internationalize within the region may rely on the political capabilities available at the core entity. According to Vassolo et al. (2011), the institutional environment in Latin America is highly volatile because of poor regulation, lack of enforcement, high corruption and a discretionary capacity of governments to change regulations. Under these conditions, the political capabilities of diversified business groups may secure favorable treatment. Despite most of these capabilities being location bound (Henisz, 2003; Meyer, 2006; Tan and Meyer, 2010), firms develop meta-level capabilities that can be exploited in foreign markets (Henisz, 2003). To focus on the home region increases the capacity to understand the institutional environment and to detect who the relevant actors are. Further, it helps minimize the liabilities of outsidership, as explained by Johansson and Valhne (2009). As a consequence, the efficiency of the location bound firm specific advantages is enhanced.

Finally, Guillen $(2002 ; 2003)$ argued that firms may learn from the experience of other firms, especially under conditions of uncertainty. Given that not only the strong group identity within business groups favors information sharing and organizational learning, but also that internationalization entails high levels of uncertainty (Guillen, 2002), business group affiliated firms may profit from the previous international experience of other affiliated firms in the same or similar types of countries. Since most of the FDI from Latin American countries targets other countries within the region (ECLAC, 2005), most of the relevant international experience within the group may be location bound. Members of a group may share information about not only the existing potential for new entrants but also suitable strategies to pursue in these markets (Guillen, $2002 ; 2003)$. By providing this type of information, business group diversification increases the 
capacity to understand appropriate responses in foreign countries within the region, minimize the complexities of internationalization and increase the capacity of their affiliates to gain legitimacy abroad. Therefore:

H3: The impact of BG diversification on the relationship between scope of operations and firm performance is more positive for affiliated firms that internationalize within the region.

\section{METHODS}

Sample

Following Aulakh, Kotabe and Teegen (2000), we select three major countries within Latin America as the focus of our study: Chile, Brazil and Mexico. To select our sample, we used two sources: the 2008 ranking of the 500 largest companies in Latin America provided by America Economia magazine and firms that are publicly traded in the NYSE. However, the ranking included the largest firms in the region considering both companies headquartered in Latin America as well as outside the region (i.e. Walmart Mexico). Given that we are interested in Latin American firms, we used the corporate affiliations database compiled by Lexis Nexis Business Data Group to identify subsidiaries of non-Latin American firms. These firms were eliminated from the data. Next, companies from banking and financial service sectors were excluded from the sample because they do not have comparable performance measures (Ruigrok, Amann and Wagner, 2007).

The final sample consists of 363 firm-year observations from 56 firms giving an average of 6.5 years of data per company. As a consequence, we are dealing with an unbalanced dataset. The fixed effect model described below helps to address this problem.

Variables 
Dependent variable. We use return on assets (ROA) as a proxy of performance. ROA is one of the most commonly employed measures in the international business and strategy literatures (Daniels and Bracker, 1989; Gomes and Ramaswamy, 1999; Haar, 1989; Kim, Hoskisson and Wan, 2004). We obtained the required financial information to calculate ROA from annual reports or SEC files.

Independent variables: The main independent variable is scope of international operations. Following Vermeulen and Barkema (2003), to capture scope of international operations we use the number of countries in which the focal firm has operating activities. We obtained the required information from annual reports or SEC files.

To estimate the moderating effects, we need to calculate the level of business group diversification. To capture business group diversification, we need first to identify the business groups' affiliated firms. To identify business groups in each country, we used several sources. For Brazil, we used the ranking of "the 100 maiores grupos" (the 100 biggest groups) published in 2009 by Exame Magazine (containing information of 2008). In this ranking, Exame provided a list of the main controlled companies associated with each of the groups identified. For Chile, we used the report "principales grupos empresariales Chilenos" (main Chilean Business Groups) published by Universidad del Desarrollo in 2008. We directly contacted Patricio Cortes, one of the leading authors of this report, who provided the names of the major companies associated with the 33 biggest business groups in Chile. Next, we obtained the annual reports of these major firms and identified the subsidiaries related to these companies. For Mexico, we used the ranking of "the 100 empresarios mas importantes del 2008" (The 100 most important businessmen of 2008) published by Expansion Magazine. This ranking provided the name of the major 
companies associated with each businessman in Mexico. Next, we obtained the annual reports of these major firms and identified the subsidiaries related to these companies.

To capture group diversification, we followed the approach of Khanna and Palepu (2000a, 2000b) by considering the number of industries in which the business group affiliates participate. To determine the number of industries, we identified the industries in which each member of a particular group is involved (whether included or not in our sample) using the 2 digit SIC codes obtained from Compustat, Mergent or the company profiles provided by Lexis Nexis Business Data Group. When necessary, missing SIC codes were added by matching company product descriptions with the applicable SIC code. The resulting variable was mean centered to minimize problems of multicollinearity (Aiken and West, 1991).We recognize that entropy or Herfindahl measures are more accurate to portray the extent of product diversification of firms. However, unavailability of segment data prevents the accurate construction of such measures. Therefore, our measure of business group diversification (BG diversification) is the count of industries in which the group participates. This is a time invariant variable captured in 2008.

To determine whether the focal MNE was internationalizing within the region, we considered region as the Americas (North, Central and South America). If the focal company has at least one subsidiary outside the Americas, we considered this company as a non-regional multinational. Hence, the resulting measure is a dummy variable ( $1=$ regional, $0=$ non-regional). We considered North America as part of the region because of the following reasons: First, the United States has a strong influence on most Latin American countries (Vassolo et al., 2011). Second, given the immigration process, there is a large community of Hispanics in North America. For instance, Gomez-Mejia, Balkin and Cardy (2012) mentioned that the country with 
the second largest number of Spanish speakers is the United States. Further, Hispanics are the largest minority community in the United States (USA Today, 2003). Finally, there are strong economic links between United States and most of Latin American countries. For instance, the United States has signed free trade agreements with Colombia, Chile, Costa Rica, Dominican Republic, El Salvador, Guatemala, Honduras, Mexico, Nicaragua, Panama and Peru (OUSTR). Further, Mexico and Chile are part of the NAFTA agreement and the United States and Brazil are consolidating their relation in recent years (STATE). In most of these processes, the participating countries need to adopt the rules of the World Trade Organization WTO (OUSTR), and as a result, the regulatory distance within the region is decreased.

To determine whether the network of subsidiaries of a focal MNE participates in a more developed or less developed institutional environment, we use the Economic Freedom of the World (EFW) index from the Fraser institute. The EFW index measures the extent to which the government protects not only the right of its individuals to conduct free and voluntary transactions but also associated property from the aggression of others (Gwartney, Lawson and Hall, 2011). The index is an aggregate measure of five dimensions: size of government, legal structure and property rights, access to sound money, freedom to trade internationally and regulation of credit, labor and business. To classify each network as more developed or less developed, we first calculate the distance in the EFW index between the home country and all the host countries in which the focal MNE has subsidiaries. Second, we calculate the sum of those differences in each year. If the resulting sum was higher than zero, we classified the international network as more developed. Otherwise, we classified the international network as less institutionally developed. Hence, the resulting measure is a dummy variable ( $1=$ more developed, $0=$ less developed). 
Control variables. Following previous research, we control for company size (total assets) and company age (number of years from inception) To minimize problems of multicollinearity, we mean centered degree of internationalization and company age. All time invariant effects are controlled by this statistical model.

Model Specification

To test the hypotheses developed in this paper, we used panel data. With panel data, pooled OLS regression is not appropriate (Baum, 2006). The assumptions of normality, homoscedastic variance across occasions and individuals, and independent and identically distributed errors do not hold in longitudinal studies (Singer and Willet, 2003). To deal with these problems, we used panel data models. To decide whether we would use random or fixed effects, we conducted the Hausman Test that examined the hypothesis that the error term of the random effects model is not correlated with the regressors (Baum, 2006; Wooldridge, 2002). Our results rejected this hypothesis, favoring the use of fixed effects models.

Given that two of our hypotheses involved three way interactions, we divided our sample into regional and non-regional firms and into more-developed and less-developed networks of subsidiaries. We need to assess whether there are significant differences between these groups in each of these cases.

\section{RESULTS}

Table 6 presents the descriptive statistics and the correlation matrix for the variables of interest. To check for potential problems associated with multicollinearity, we analyze Variance Inflation Factors (VIF). The mean VIF reported was 1.03 and all scores are less than 2, considerably lower than the standard cut off point of 10 (Hair, Anderson, Tatham, and Black, 1998). As reported by the non-transformed variables, not only do the Latin American 
multinationals included in the sample tend to be fairly old (48 years old) and large $(6,635$ US\$M), but also they are at early stages of the internationalization process. (The average scope of operations is three countries.)

Table 6: Descriptive statistics and correlations for variables included in essay 3

\begin{tabular}{lrrrrrrrrr}
\hline & OBS & MEAN & S.D. & VIF & 1 & 2 & 3 & 4 & 5 \\
\hline 1. ROA & 363 & 0.05 & 0.07 & & 1 & & & & \\
2. SIZE & 363 & 6704 & 24964 & 1.02 & -0.06 & 1 & & \\
3. AGE & 363 & 48.40 & 29.88 & 1.04 & -0.01 & 0.06 & 1 & & \\
4. Business group diversification & 363 & 0.00 & 5.39 & 1.04 & 0.12 & -0.09 & 0.17 & 1 & \\
5. Scope of internationalization & 363 & 0.00 & 1.23 & 1.01 & 0.03 & 0.09 & 0.01 & 0.00 & 1 \\
\hline
\end{tabular}

MEAN VIF 1.03

Table 7 presents the results of the fixed effects models used to test the hypothesized relations. It is important to notice that panel data models report three R-squares, of which interpretation varies depending on the type of model used. The relevant R-square for fixed effects models is the R-square within (StataCorp, 2005).

Our first hypothesis predicted a positive moderating effect of business group diversification on the relationship between scope of international operation and firm performance. We test this hypothesis in model 2 in table 7 . We found a marginally positive moderating effect of business group diversification on the M-P relationship $(\mathrm{p}<0.10)$. Hence, we considered that our first hypothesis is partially supported.

Our second hypothesis argued in favor of a more positive effect of business group diversification on the relationship between scope and firm performance for firms that internationalize to other emerging economies or to least develop economies. We test this hypothesis in models 3, 4 and 5. In model 3, we assess the moderating effect of business group diversification for MNEs that internationalize into more developed countries. 
Table 7: The impact of business group diversification on firm performance

\begin{tabular}{|c|c|c|c|c|c|c|c|c|}
\hline \multirow[b]{3}{*}{ Variables } & \multirow{3}{*}{$\begin{array}{l}\text { Model } 1 \\
\text { Base } \\
\text { Model }\end{array}$} & \multirow{3}{*}{$\begin{array}{l}\text { Model } 2 \\
\text { Overall } \\
\text { effect }\end{array}$} & \multicolumn{3}{|c|}{ More developed vs less developed } & \multicolumn{3}{|c|}{ Regional vs. Non regional } \\
\hline & & & Model 3 & Model 4 & Model 5 & Model 5 & Model 6 & Model 7 \\
\hline & & & $\begin{array}{l}\text { More } \\
\text { developed }\end{array}$ & $\begin{array}{l}\text { Less } \\
\text { developed }\end{array}$ & $\begin{array}{l}\text { LD_no } \\
\text { domestic }\end{array}$ & Region & $\begin{array}{l}\text { Region non- } \\
\text { domestic }\end{array}$ & $\begin{array}{l}\text { Non- } \\
\text { Region }\end{array}$ \\
\hline \multirow[t]{2}{*}{ Constant } & $-.3021 * *$ & $-0.3250 * *$ & $-.3140 * *$ & $-.2738 * *$ & $-0.1739 * *$ & $-.2929 * *$ & $-0.2700 * *$ & $-0.5248 * *$ \\
\hline & 0.0427 & 0.0630 & 0.0915 & 0.0535 & 0.0870 & 0.0481 & 0.0847 & 0.1166 \\
\hline \multirow[t]{2}{*}{ AGE } & $.0073 * *$ & $0.0074 * *$ & $.0078^{* *}$ & $.0067^{* *}$ & $0.0034 * *$ & $.0072 * *$ & $0.0062 * *$ & $0.0113 * *$ \\
\hline & 0.0009 & 0.0012 & 0.0019 & 0.0011 & 0.0016 & 0.0010 & 0.0016 & 0.0023 \\
\hline \multirow[t]{2}{*}{ SIZE } & 0.0000 & 0.0000 & 0.0000 & 0.0000 & 0.0000 & 0.0000 & 0.0000 & 0.0000 \\
\hline & 0.0000 & 0.0000 & 0.0000 & 0.0000 & 0.0000 & 0.0000 & 0.0000 & 0.0000 \\
\hline \multirow[t]{2}{*}{ Scope } & -0.0023 & $-.0041+$ & -0.0024 & -0.0012 & -0.0033 & -0.0049 & $-0.0066+$ & -0.0044 \\
\hline & 0.0016 & 0.0021 & 0.0040 & 0.0039 & 0.0026 & 0.0036 & 0.0039 & 0.0032 \\
\hline \multirow{2}{*}{$\begin{array}{l}\text { Scope* } \\
\text { BG } \\
\text { diversification }\end{array}$} & & $.0006+$ & 0.0001 & 0.0006 & -0.0005 & $.0009+$ & $0.0011 *$ & 0.0003 \\
\hline & & 0.0004 & 0.0009 & 0.0005 & 0.0005 & 0.0005 & 0.0005 & 0.0007 \\
\hline R-sq within & 0.0989 & 0.1222 & 0.0925 & 0.0933 & 0.2968 & 0.0979 & 0.1119 & 0.2234 \\
\hline R-sq between & 0.0044 & 0.0453 & 0.0376 & 0.022 & 0.0414 & 0.0036 & 0.053 & 0.0014 \\
\hline R-sq overall & 0.0001 & 0.0203 & 0.0458 & 0.0096 & 0.0274 & 0.0003 & 0.0342 & 0.0018 \\
\hline $\mathrm{N}$ of observations & 742 & 363 & 215 & 527 & 147 & 626 & 247 & 116 \\
\hline $\mathrm{N}$ of firms & 98 & 56 & 43 & 85 & 32 & 90 & 46 & 23 \\
\hline
\end{tabular}

$+\mathrm{p}<0.10 ; *^{\mathrm{p}}<0.05 ; * * \mathrm{p}<0.01$ 
In models 4 and 5, we evaluate the impact of business group diversification on firms that internationalize into similar or less developed economies. The difference between models 4 and 5 is that in model 4 we include companies that are domestic while in model 5, we only focused the analysis on MNEs. Unfortunately, our empirical evidence does not support this hypothesis. None of the interacting terms (in models 3, 4 and 5) reach significant levels. Hence, this hypothesis was not supported.

Our last hypothesis predicts a more positive effect of business group diversification on the relationship between scope and performance for firms that internationalize within the region. We test this hypothesis in models 5, 6 and 7. Osegowitsch and Sammartino (2008) mentioned that Rugman and Verbeke's classification does not discriminate between purely domestic companies and home region companies. As such, we really cannot assess the capacity of nonlocation specific assets to be deployable within the home region and it is possible that the concept of regionalization is biased in favor of regionalization because of domestic firms. For such reason, we have developed two models that try to capture the effect of business group diversification within the region. In model 5 , we assess its impact on the region including domestic firms. In model 6 , we evaluate the impact of business group diversification only in multinationals that internationalize within the region. In model 7 , we evaluate the impact on firms that internationalize outside the region. While in model 5 we found a marginally positive effect of business group diversification on the scope performance relationship $(\mathrm{p}<0.10)$, in model 6 , this effect is stronger $(\mathrm{p}<0.05)$ providing strong empirical evidence in favor of the regionalbound nature of the firm specific advantages possessed in the core entity. Moreover, these significant results are also associated with an important increment in the coefficient of determination $\left(\mathrm{R}^{2}\right)$. Hence, we consider that our third hypothesis was supported. 
Overall, we found support for one hypotheses and partial support for another one. Further, we did not find support for our remaining hypothesis.

\section{DISCUSSION}

Considering that emerging markets are adopting pro-market reforms (Cuervo-Cazurra and Dau, 2009a; 2009b) and the need of diversified business groups to distribute their large overhead, we assess the capacity of business group diversification to generate value in the internationalization of their affiliates. In particular, we explore the extent to which business group diversification moderates the relationship between international scope and firm performance. Our statistical evidence suggests that business group diversification effectively moderates such a relation.

Several mechanisms may account for our results. For instance, the previous experience in the same or similar markets of other business affiliated firms may help the focal firm to minimize the uncertainty in those foreign countries. Alternatively, the core entity of the diversified business group might use its non-market resources to benefit the internationalization process of their affiliates. Since it is in the core entity where the administrative and financial control of the resources available in the diversified business group resides, business groups might deploy such resources to their affiliates in the case of need. However, given the characteristics of the nonmarket resources possessed by diversified business groups, we believe that their importance varies depending upon the institutional context in which they are applied.

Given that the existence of institutional voids and high transactions costs is one of the most common explanations of the existence and capacity to generate value of diversified business groups, we expect that going to other institutional settings with similar problems may contribute with the leverage of the non-market resources available and hence, positively impact 
to the performance of their affiliates. Unfortunately, we failed to find statistical evidence for this hypothesis.

A potential explanation is related with our definition of developed or less developed economies. We use the EFW and the associated distances within the network of subsidiaries to calculate the cut-off point that helps us to define the level of development of the environment in which the focal MNE has operations. However, this is an arbitrary decision that may affect the content and construct validity of our measure. Another explanation may be related with the theoretical inconsistencies about the effect of distance on international business. For instance, on the one side, Berry, Guillen and Zhou (2010) stress the importance of concentrating on specific dimensions of distance that are related to our research question. Cuervo-Cazurra and Genc (2011) further argued that the advantage or disadvantage of emerging multinationals in comparison with developed country firms depends on the dimension of distance analyzed. On the other side, Rugman et al. (2011) argued that the effect of the different distance dimensions cannot be isolated and what matters is the compound distance across multiple dimensions. This lack of consistency on the impact of distance and the dimensions that need to be analyzed also may affect the lack of consistent results.

We do find statistical evidence in favor of the regionally bound nature of these nonmarket resources. While most of the traditional arguments associated with regionalization theory focused on market based resources (i.e. Rugman and Verbeke, 2004; 2007; 2008a; 2008b), our results suggest that the deployment of non-market resources abroad also decay across regions. Diversified business groups developed at home those non-market resources that help their affiliates to respond more efficiently in similar environments (Cuervo-Cazurra, 2006; Holbrun and Zelner, 2010). Given the similarities across the countries within the region (Rugman and 
Verbeke; 2004; 2008a; 2008b), diversified business groups may use their market substitute mechanisms to obtain scarce resources in these countries. Further, their understanding of the institutional environments may help business group affiliated firms not only to minimize the managerial and coordination challenges related to the internationalization process but also to increase their understanding of the rules to compete in different host countries within the region and therefore, enhance their legitimacy.

Sensitivity Analysis

A critical point in our study is related to our classification scheme. Flores and Aguilera (2007) argued that a point of concern in the regionalization-globalization debate is partition of the world and the definition of region. In our study, we classified region as the Americas (North, Central and South America). However, while reasonable, such definition is somehow arbitrary. To address this problem, we explore three different classifications schemes and analyze how the moderating effect of business group diversification on the scope-performance relationship is impacted by those classifications.

We base our different classification schemes on the United Nations regional categories. In models 2 and 3 of table 8, we considered Central America and Caribbean UN regional categories as the home region for Mexican firms. For Brazilian and Chilean firms, we considered the UN category of South-America as the home region. In models 4 and 5 of table 8, we considered Central America, Caribbean and South-America UN regional categories to define the relevant home region for Brazilian, Chilean and Mexican firms. Finally, in models 6 and 7 of table 8, we considered as region the Americas and we included North, Central and South America and the Caribbean. All the analyses shown in table 8 are based on non-domestic firms. The analysis of regions including domestic firms (not reported here) presents similar results. 
Table 8: The impact of business group diversification on firm performance by regional classification scheme.

\begin{tabular}{|c|c|c|c|c|c|c|c|}
\hline Variables & $\begin{array}{l}\text { Model } 1 \\
\text { Overall } \\
\text { effect }\end{array}$ & $\begin{array}{l}\text { Model } 2 \\
\text { Region } 1 \\
\end{array}$ & $\begin{array}{l}\text { Model } 3 \\
\text { Non- } \\
\text { Region1 }\end{array}$ & $\begin{array}{l}\text { Model } 4 \\
\text { Region } 2\end{array}$ & $\begin{array}{l}\text { Model } 5 \\
\text { Non-region2 }\end{array}$ & $\begin{array}{l}\text { Model } 6 \\
\text { Region } 3\end{array}$ & $\begin{array}{l}\text { Model } 7 \\
\text { Non- } \\
\text { Region3 }\end{array}$ \\
\hline Constant & $\begin{array}{r}-0.3250^{* *} \\
0.0630\end{array}$ & $\begin{array}{r}-0.3572 * \\
0.1545\end{array}$ & $\begin{array}{r}-0.3524 * * \\
0.0686\end{array}$ & $\begin{array}{r}-0.2163+ \\
0.1221\end{array}$ & $\begin{array}{r}-0.3916^{* *} \\
0.0750\end{array}$ & $\begin{array}{r}-0.2700 * * \\
0.0847\end{array}$ & $\begin{array}{r}-0.5248 * * \\
0.1166\end{array}$ \\
\hline AGE & $\begin{array}{r}0.0074 * * \\
0.0012\end{array}$ & $\begin{array}{r}0.0064 * * \\
0.0023\end{array}$ & $\begin{array}{r}0.0092 * * \\
0.0016\end{array}$ & $\begin{array}{r}0.0046^{*} \\
0.0019\end{array}$ & $\begin{array}{r}0.0102 * * \\
0.0018\end{array}$ & $\begin{array}{r}0.0062 * * \\
0.0016\end{array}$ & $\begin{array}{r}0.0113 * * \\
0.0023\end{array}$ \\
\hline SIZE & $\begin{array}{l}0.0000 \\
0.0000\end{array}$ & $\begin{array}{l}0.0000 \\
0.0000\end{array}$ & $\begin{array}{l}0.0000 \\
0.0000\end{array}$ & $\begin{array}{l}0.0000 \\
0.0000\end{array}$ & $\begin{array}{l}0.0000 \\
0.0000\end{array}$ & $\begin{array}{l}0.0000 \\
0.0000\end{array}$ & $\begin{array}{l}0.0000 \\
0.0000\end{array}$ \\
\hline Scope & $\begin{array}{r}-.0041+ \\
0.0021\end{array}$ & $\begin{array}{r}-0.0016 \\
0.0159\end{array}$ & $\begin{array}{r}-0.0054^{*} \\
0.0021\end{array}$ & $\begin{array}{r}-0.0058 \\
0.0050\end{array}$ & $\begin{array}{r}-0.0045+ \\
0.0025\end{array}$ & $\begin{array}{r}-0.0066+ \\
0.0039\end{array}$ & $\begin{array}{r}-0.0044 \\
0.0032\end{array}$ \\
\hline $\begin{array}{l}\text { Scope* } \\
\text { BG diversification }\end{array}$ & $\begin{array}{l}.0006+ \\
0.0004\end{array}$ & $\begin{array}{r}-0.0019 \\
0.0024\end{array}$ & $\begin{array}{r}0.0009 * \\
0.0004\end{array}$ & $\begin{array}{l}0.0010 \\
0.0008\end{array}$ & $\begin{array}{l}0.0006 \\
0.0005\end{array}$ & $\begin{array}{r}0.0011 * \\
0.0005\end{array}$ & $\begin{array}{l}0.0003 \\
0.0007\end{array}$ \\
\hline R-sq within & 0.1222 & 0.0713 & 0.1787 & 0.0594 & 0.1933 & 0.1119 & 0.2234 \\
\hline R-sq between & 0.0453 & 0.0052 & 0.0507 & 0.004 & 0.017 & 0.053 & 0.0014 \\
\hline R-sq overall & 0.0203 & 0.0009 & 0.0241 & 0.0002 & 0.0238 & 0.0342 & 0.0018 \\
\hline Number of observations & 363 & 127 & 236 & 160 & 203 & 247 & 116 \\
\hline Number of firms & 56 & 23 & 43 & 30 & 38 & 46 & 23 \\
\hline
\end{tabular}

$+\mathrm{p}<0.10 ;{ }^{*} \mathrm{p}<0.05 ; * * \mathrm{p}<0.01$ 
As we can observe, the definition of region decisively impacts our results. When we use our first definition of region (models 2 and 3), we do not find empirical evidence supporting our argument that business group diversification moderates the relationship between international scope and firm performance. In fact, we found a positive moderating effect on multinationals that operate outside of the defined region. These findings may suggest that the non-market resources possessed are not regionally bound and that affiliated firms are better off exploiting them globally.

However, to further understand whether there are geographical limits to deploying these FSAs abroad, we explore alternative definitions of region. In our second definition, we failed to find statistical results supporting the moderation of business group diversification in either regional or non-regional multinationals. While our results showed the hypothesized relations, we failed to reach significance. However, when we use our third definition of region (considering North-America, Central-America, Caribbean and South America), we found a positive moderating effect on regional firms but not on non-regional MNEs. It seems that the non-market resources available within diversified business groups indeed have limits to be exploited. Further, their international leverage is constrained to the Americas. Beyond the Americas, diversified business groups and their non-market resources have little capacity to positively impact the internationalization of their affiliates.

Rugman and Verbeke (2008a) argued that distance is important. However, distance matters the most between regions than within regions. Companies that internationalize across regions face liabilities of inter-regional foreignness (Rugman and Verbeke, 2007). In the case of business group diversification, the lack of understanding of institutional environments may limit deployment of these non-market resources. For instance, this lack of understanding may prevent 
diversified business groups from efficiently using their political resources to overcome the "liabilities of outsidership" (Johansson and Valhne, 2009) of their affiliates when these firms venture outside the region.

Flores and Aguilera (2007) mentioned that one of the critical points in the globalization versus regionalization discussion is the definition of region. We believe that our results support the regionalization scheme proposed by Rugman and Verbeke (2004; 2007; 2008a; 2008b). It is only when North America is included in the sample that the proposed moderating effects reach significance. These findings also signal the importance of North America for Latin American firms. Given the economic importance of this region, business group affiliated firms from the region not only may reach economies of scale and scope by entering these large markets but also they can leverage the non-market resources and previous experience of other affiliated firms to develop and implement efficient strategies.

\section{LIMITATIONS AND DIRECTIONS FOR FUTURE RESEARCH}

Despite business groups facing strong pressures to refocus their operations, they have the alternative to distribute their large overhead and generate value for their affiliates by encouraging these affiliated firms to internationalize. In fact, our results suggest that diversified business groups positively moderate the relationship between international scope and firm performance. Nevertheless, this capacity is stronger when diversified business groups have the chance of using their non-market resources in other countries within the Americas. Within the region, diversified business groups do not require extensive investment in complementary assets to exploit their non-market resources. Further, they have a better understanding of the different institutional environments which allows them to use their market substitute mechanisms, political capabilities 
and previous experience to minimize the uncertainty and complexity associated with the foreign operations of their affiliates.

However, our results should be interpreted with caution. First, we have limitations to define our measures. For instance, we defined that a company is regional if the focal firm had all their subsidiaries in the Americas. Nevertheless, to be classified as non-regional, it was necessary to have only one subsidiary in other region. The focal firm may have several units in the region (i.e. ten subsidiaries) and only one subsidiary outside the region and it will be classified as nonregional. Indeed, we did not discriminate between a firm that has a small percentage of operating units outside the home region and one that has a large percentage of subsidiaries outside the region. We considered both of them as non-regional. Future research may explore more refined measures of regionalization (or more exactly non-regionalization) and assess whether the impact of operating above and beyond the home region depends on the number of subsidiaries in these host regions, on the importance of those subsidiaries or on the location of the subsidiaries.

Further, to identify business groups we rely on different publications with different methodologies. Moreover, to capture diversification of these business groups we count the SIC codes of their affiliated firms following Khanna and Palepu (2000a; 2000b). While recognizing that a herfindhal measure may be more accurate to determine the extent of diversification of business groups, unavailability of data is a major constraint to building such index. Hence, our business group diversification measure may have problems with deficiency and contamination. Future research should account for these limitations.

Second, we relate the positive moderating effect of business group diversification with the possession of non-market resources and the potential of these non-market resources to be exploited abroad. Nevertheless, we did not measure these non-market resources. Future research 
may account for this limitation and identify specific non-market resources that can be used in the internationalization of their affiliates. Content analytic techniques may give some avenues in this area.

Third, we assess the impact of business group diversification on the internationalization of their affiliates. Carney et al. (2011) argued that the effects of business groups should be assessed at the business group level and not in their affiliates. A future avenue of research may explore the internationalization process at the group level. For instance, by assessing the degree of international operations at the group level we can have more direct evidence of their capacity to leverage their resources abroad.

Granovetter (2005) argued that the demise of diversified business groups is not necessary related to the improvement of market conditions and reduction of transaction costs. In fact, Khanna and Palepu (1999b) found that in Chile and India, diversified business groups responded to the adoption of pro-market reforms with efficiency improvements in their market-substitute mechanisms that allows them to increase their performance. In this paper, we found evidence that in the presence of institutional changes, business group diversification has the capacity to positively impact the internationalization of their affiliates by increasing their performance prospects, especially when the focal affiliate internationalizes within the home region. 


\section{REFERENCES}

Agmon T, Lessard D. 1977. Investor recognition of corporate international diversification. The Journal of Finance 32(4): 1049-1055.

Aiken L, West S. 1991. Multiple Regression: Testing and Interpreting Interactions. Newbury Park, CA: Sage.

Aulakh P, Kotabe M, Teegen H. 2000. Export strategies and performance of firms from emerging economies: Evidence from Brazil, Chile, and Mexico. Academy of Management Journal 43(3): 342-361.

Aulakh P. 2007. Emerging multinationals from developing economies: Motivations, paths and performance. Journal of International Management 13(3): 235-240.

Baum C. 2006. An Introduction to Modern Econometrics Using Stata. College Station, TX: Stata Press.

Baum JA, Shipilov AV. 2006. Ecological approaches to organizations. In S. R.

Clegg, C. Hardy, W. Nord, \& T. Lawrence (Eds.), Handbook of organization studies: 55-110. London: Sage.

Bausch A, Krist M. 2007. The effect of context-related moderators on the internationalizationperformance relationship: Evidence from meta-analysis. Management International Review 47(3): 319-347.

Berry H, Guillen MF, Zhou N. 2010. An institutional approach to cross-national distance. Journal of International Business Studies 41: 1460-1480.

Biggart NW, Guillen MF. 1999. Developing difference: Social organization and the rise of the auto industries of South Korea, Taiwan, Spain, and Argentina. American Sociological Review 64(5): 722-747.

Blomstermo A, Sharma D, Sallis, J. 2006. Choice of foreign market entry mode in service firms. International Marketing Review 23(2):211-229.

Boddewyn J, Halbrich M, Perry, A. 1986. Service multinationals: conceptualization, measurement and theory. Journal of International Business Studies 17(3): 41-53.

Bonaglia F, Goldstein A, Mathews JA. 2007. Accelerated internationalization by emerging markets' multinationals: The case of the white goods sector. Journal of World Business 42(4): 369-383.

Bowen D, Jones G. 1986. Transaction Cost Analysis of Service Organization-Customer Exchange. Academy of Management Review 11(2): 428-441. 
Brenes E. 2000. Strategies for globalizing Latin American business. Journal of Business Research 50(1): 3-7.

Brenes E, Dominguez L. 1997. Strategic choices in the new international enterprise in Latin America. Journal of Business Research 38(1): 1-2.

Brewer H.1981. Investor benefits from corporate international diversification, Journal of Financial and Quantitative Analysis 16(1): 113-126.

Burt, RS. 1992. Structural Holes: The social structure of competition. Harvard University Press.

Campbell A, Verbeke A. 1994. The globalization of service multinationals. Long Range Planning 27(2): 95-102.

Capar N, Kotabe M. 2003. The relationship between international diversification and performance in service firms, Journal of International Business Studies 34(4): 345-355.

Carney M, Gedajlovic ER, Heugens PP, Van Essen M, Van Oosterhout J. 2011, forthcoming. Business group affiliation, performance, context and strategy: A meta analysis. Academy of Management Journal 54(3).

Chacar A, Vissa B. 2005. Are emerging economies less efficient? Performance persistence and the impact of business group affiliation. Strategic Management Journal 26(10): 933-946.

Chakrabarti A, Singh K, Mahmood I. 2007. Diversification and performance: evidence from East Asian firms. Strategic Management Journal 28(2): 101-120.

Chakrabarti A, Vidal E, Mitchell W. 2011. Business transformation in heterogeneous environments: The impact of market development and firm strength on retrenchment and growth reconfiguration. Global Strategy Journal 1: 6-26.

Chang S, Hong J. 2002. How much does the business group matter in Korea? Strategic Management Journal 23(1): 265-274.

Chatterjee S, Wernerfelt B. 1991. The link between resources and type of diversification: theory and evidence. Strategic Management Journal 12(1): 33-48.

Chudnovsky D, Lopez A. 2004. Transnational corporations' strategies and foreign trade patterns in MERCOSUR countries in the 1990s. Cambridge Journal of Economics 28 (5): 635-652.

Chung, C. 2001. Markets, culture and institutions: The emergence of large business groups in Taiwan, 1950s-1970s. Journal of Management Studies 38(5): 719-745.

Coase RH. 1937. The nature of the firm. Economica 4(16): 386 - 405. 
Contractor F, Kundu S, Hsu C. 2003. A three-stage theory of international expansion: The link between multinationality and performance in the service sector. Journal of International Business Studies 34(1): 5-18.

Contractor F, Kumar V, Kundu S. 2007. Nature of the relationship between international expansion and performance: The case of emerging market firms. Journal of World Business 42(4): 401-425.

Contractor F. 2007. Is international business good for companies? The evolutionary or multistage theory of internationalization vs. the transaction cost perspective. Management International Review 47(3): 453-475.

Cuervo-Cazurra A. 2006. Who cares about corruption? Journal of international business studies 37:807-822.

Cuervo-Cazurra A. 2007. Sequence of value-added activities in the internationalization of developing country MNEs. Journal of International Management 13(3): 258-277.

Cuervo-Cazurra A. 2008. The multinationalization of developing country MNEs: the case of multilatinas. Journal of International Management 14(2): 138-154.

Cuervo-Cazurra A, Dao L. 2009a. Structural reform and firm exports. Management International Review 49(4): 479-507.

Cuervo-Cazurra A, Dao L. 2009b. Promarket reforms and firm profitability in developing countries. Academy of Management Journal 52(6): 1348-1368.

Cuervo-Cazurra A, Genc ME. 2008. Transforming disadvantages into advantages: developing country MNEs in the least developed countries. Journal of international business studies 39: 957979.

Cuervo-Cazurra A, Genc ME. 2011. Obligating, pressuring, and supporting dimensions of the environment and the non-market advantages of developing country multinational companies. Journal of management studies 48(2): 441-455.

Daniels JD, Bracker J. 1989. Profit performance: Do foreign operations make a difference? Management International Review 29(1): 46-56.

De Soto H. 2000. The Mystery of Capital: Why Capitalism Triumphs in the West and Fails Everywhere Else. New York: Basic Books.

Delios A, Henisz WJ. 2003. Political hazards, experience and sequential entry strategies: The international expansion of Japanese firms, 1980-1998. Strategic Management Journal 24: 11531164. 
Deng P. 2003. Foreign investment by multinationals from emerging countries. The case of China. Journal of Leadership and Organizational Studies 10(2): 113-124.

Diaz-Hermelo F, Vassolo R. 2010. Institutional development and hypercompetition in emerging economies. Strategic Management Journal 31(13): 1457-1473.

Dierickx I, Cool K. 1989. Asset stock Accumulation and sustainability of competitive advantage. Management Science 35(12): 1504-1514.

DiMaggio PJ, Powell WW. 1983. The iron cage revisited - Institutional isomorphism and collective rationality in organizational fields. American Sociological Association 48(2): 147-160.

Douma S, George R, Kabir, R. 2006. Foreign and domestic ownership, business groups and firm performance: evidence from a large emerging market. Strategic Management Journal 27(7): 637657.

Dunning JH. 1993. Multinational enterprises and the global economy. Wokingham: Addison Wesley.

Dunning J, Kim C, Park D. 2008. Old wines in new bottles: a comparison of emerging-market TNCs today and developed-country TNCs thirty years ago. In The Rise of Transnational Corporations From Emerging Markets: Threat Or Opportunity?, Sauvant KP (eds). Edward Elgar Pub: Northampton, MA; 158-180.:

ECLAC (Economic Comission for Latin America and the Caribbean). 2005. Foreign investment in Latin American and the Caribbean. http://www.eclac.org/publicaciones/xml/2/24302/lcg2309i.pdf (5 April 2007).

Ekeledo I, Sivakumar K. 1998. Foreign market entry mode choice of service firms: A contingency perspective. Journal of the Academy of Marketing Science 26(4): 274-292.

Ekeledo I, Sivakumar K. 2004. International market entry mode strategies of manufacturing firms and service firms a resource-base perspective. International Marketing Review 21(1): 68101.

Enderwick P. 1989. Multinational Service Firms. Routledge: New York.

Erramilli MK. 1990. Entry mode choice in service industries. International Marketing Review 7(5): 50-62.

Erramilli MK, Rao CP. 1993. Service firms' international entry-mode choice: 4 modified transaction-cost analysis approach. Journal of Marketing 57(3): 19-38.

Estrin S, Wright M.1999. Corporate governance in the former Soviet Union: An overview of the issues. Journal of Comparative Economics, 27: 398-421. 
Flores RG, Aguilera RV. 2007. Globalization and location choice: an analysis of US multinational firms in 1980 and 2000. Journal of International Business Studies 38(7): 11871210 .

Garcia-Canal E, Guillen MF. 2008. Risk and the strategy of foreign location choice in regulated industries. Strategic Management Journal 29: 1097-1115.

Ghemawat P, Khanna, T. 1998. The nature of diversified business groups: A research design and two case studies. Journal of industrial economics 46(1):35-61.

Glaum M, Oesterle MJ. 2007. 40 Years of Research on Internationalization and Firm Performance: More Questions than Answers? Management International Review 47(3): 307-317.

Goerzen A, Beamish P. 2003. Geographic scope and multinational enterprise performance. Strategic Management Journal 24(13): 1289-1306.

Goerzen A, Makino S. 2007. Multinational corporation internationalization in the service sector: a study of Japanese trading companies. Journal of International Business Studies 38(7): 11491169.

Goldman Sach. 2007. BRICs and beyond. http://www2.goldmansachs.com/ideas/brics/BRICsand-Beyond.html. (10 August 2009).

Gomes L, Ramaswamy K. 1999. An empirical examination of the form of the relationship between multinationality and performance. Journal of International Business Studies 30(1): 173188.

Gomez-Mejia LR, Balkin DB, Cardy RL. 2012. Managing human resources. Upper Saddle River, NJ: Prentice Hall.

Granovetter M. 1994. Business groups. In The Handbook of economic sociology, Smelser, NJ, Swedberg, R (eds). Princeton University Press: Princeton, NY: 453-475.

Granovetter M. 2005 Business group and social organization. In The Handbook of economic sociology, Smelser, NJ, Swedberg, R (eds). Princeton University Press: Princeton, NY: 429-450.

Grant RM. 1987. Multinationality and performance among British manufacturing companies. Journal of International Business Studies 18(3):79-89.

Ghemawat P, Khanna T. 1998. The nature of diversified business groups: A research design and two case studies. Journal of Industrial Economics, 46: 35-62.

Guillen M. 2000. Business groups in emerging economies: A resource-based view. Academy of Management Journal 43(3): 362-380. 
Guillen M. 2002. Imitation, inertia and foreign expansion: South Korean firms and business groups in China, 1987-1995. Academy of Management Journal 45(3): 509-525.

Guillen M. 2003. Experience, imitation, and the sequence of foreign entry: wholly owned and joint-venture manufacturing by South Korean firms and business groups in China, 1987-1995. Journal of International Business Studies 34(2):185-198.

Gwartney J, Lawson R, Hall J. 2011. Economic Freedom of the World: 2011 Annual Report. Fraser institute. Fraser Institute. http://www.freetheworld.com/2011/reports/world/EFW2011_complete.pdf (15 september 2011).

Gurhan-Canli Z, Maheswaran D. 2000. Cultural variations in country of origin effects. Journal of Marketing Research 37(3): 309-317.

Haar J. 1989. A comparative analysis of the profitability performance of the largest US, European and Japanese multinational enterprises. Management International Review 29(3): 5-18.

Hair JF, Anderson RF, Tatham RL, Black WC.1998. Multivariate data analysis. Prentice Hall: Upper Saddle River, NJ.

Hannan MT, Freeman J. 1984. Structural inertia and organizational change. American Sociological Review 49(2): 149-164.

Henisz, WJ. 2003. The power of the Buckley and Casson thesis: The ability to manage institutional idiosyncrasies. Journal of international business studies 34: 173-184.

Hennart JF. 2007. The theoretical rationale for a multinationality-performance relationship. Management International Review 47(3): 423-452.

Hennart JF. 2011. A theoretical assessment of the empirical literature on the impact of multinationality on performance. Global Strategy Journal 1(1): 135-151.

Hitt MA, Hoskisson RE, Kim H. 1997. International diversification: Effects on innovation and firm performance in product-diversified firms. Academy of Management Journal 40(4): 767-798.

Holburn GLF. 2001. Regulatory Institutions and Firm Strategy: Theory and Evidence from the Electric Power Industry. Unpublished doctoral dissertation, University of California, Berkeley.

Holburn GL, Zelner BA. 2010. Political Capabilities, Policy Risk, and international investment strategy from the global electric power generation industry. Strategic Management Journal 31(12): 1290-1315.

Hoskisson RE, Cannella AA, Tihanyi L, Faraci R. 2004. Asset restructuring and business group affiliation in French civil law countries. Strategic Management Journal 25(6): 525-539. 
Hoskisson RE, Eden L, Lau CM, Wright M. 2000. Strategy in emerging economies. Academy of Management Journal 43(3): 249-267.

Hoskisson RE, Johnson RA, Tihanyi L, White RE. 2005. Diversified business groups and corporate refocusing in emerging economies. Journal of Management 31(6): 941-965.

Hundley G, Jacobson CK. 1998. The effects of the keiretsu on the export performance of Japanese companies: Help or Hindrance? Strategic Management Journal 19(10): 927-937.

Hymer S. 1976. The international operations of national firms: A study of direct foreign investment. Cambridge, MA: MIT Press.

Jarillo JC, Martinez JI. 1990. Different Roles for Subsidiaries: The Case of Multinational Corporations in Spain. Strategic Management Journal 11(7): 501-512.

Johanson J, Vahlne JE. 1977. The internationalization process of the firm: A model of knowledge development and increasing foreign market commitment. Journal of International Business Studies 8(1):23-32.

Johanson J, Vahlne JE. 1990. The mechanism of internationalisation. International Marketing Review 7(4): 11-24.

Johanson J, Vahlne JE. 2009. The Uppsala internationalization model revisited: From Liabilities of foreigness to liabilities of outsidership. Journal of International Business Studies 40(9):14111431.

Kang M, Yang S. 2010. Comparing effects of country reputation and the overall corporate reputations of a country on international consumers' product attitudes and purchase intentions. Corporate Reputation Review 13(1): 52-62.

Khanna T, Palepu K. 1997. Why focused strategies may be wrong for emerging markets. Harvard Business Review 75(4): 41-51.

Khanna T, Palepu K. 1999. The right way to restructure conglomerates in emerging markets. Harvard Business Review 77(4): 125-134.

Khanna T, Palepu K. 2000a. The future of business groups in emerging markets: Long-run evidence from Chile. Academy of Management Journal 43(3): 268-285.

Khanna T, Palepu K. 2000b. Is group affiliation profitable in emerging markets? An analysis of diversified Indian business groups. The Journal of Finance 14(2): 867-891.

Khanna T, Rivkin JW. 2001. Estimating the performance effects of business groups in emerging markets. Strategic Management Journal 22(1): 45-74. 
Khanna T, Yafeh Y. 2005. Business groups and business sharing around the world. The Journal of Business 78(1): 301-340.

Khanna T, Yafeh Y. 2007. Business groups in emerging markets: Paragons or Parasites? Journal of economic Literature 45(2): 331-372.

Kim H, Hoskisson RE, Wan WP. 2004. Power dependence, diversification strategy and performance in keiretsu member firms. Strategic Management Journal 25 (7): 613-636.

Kim H, Kim, H, Hoskisson RE. 2010. Does market-oriented institutional change in an emerging economy make business-group-affiliated multinationals perform better? An institution-based view. Journal of International Business Studies 41(7):1141-1160.

Kirca A, Hult G, Cavusgil S, Perry M, Akdeniz M, Deligonul S, Pollite W, Hoppner J, White R. 2010. Firm-specific assets, multinationality and financial performance: A Meta-analytic review and theoretical integration. Academy of Management Journal 54(1): 47-72.

Kirkman B, Lowe K, Gibson C. 2006. A quarter century of culture's consequences: A review of empirical research incorporating Hofstede's cultural values framework. Journal of International Business Studies 37: 285-320.

Kogut B. 1985. Designing global strategies: Comparative and competitive value added chains. Sloan Management Review 26(4): 15-28.

Kogut B, Singh H. 1988. The effect of national culture on the choice of entry mode. Journal of International Business Studies 19(3): 411-432.

Kogut B, Zander U. 1993. Knowledge of the firm and the evolutionary theory of the multinational corporation. Journal of International Business Studies 24(4): 625-645.

Kostova T, Zaheer S. 1999. Organizational legitimacy under conditions of complexity: The case of the multinational enterprise. Academy of Management Review 24(1): 64-81.

Kuczynski PP, Williamson J. 2003. After the Washington consensus. Restarting growth and reform in Latin America, Washington: Institute for international economics.

La Porta R, Lopez de Silanes F, Shleifer A, Vishny RW. 1997. Legal determinants of external finance. The journal of finance 52(3):1131-1150.

Lall S. 1983. The new multinationals: The spread of third world enterprises. Chichester: Wiley.

Lampert SI, Jaffe ED. 1996. Country of Origin Effects of International Market Entry. Journal of Global Marketing 10(2):27-52. 
Leff N. 1978. Industrial organization and entrepreneur-ship in the developing countries: The economic groups. Economic Development and Cultural Change 26(4): 661-675.

Li JT, Guisinger S. 1992. The globalization of service multinationals in the triad region: Japan, Western Europe and North America. Journal of International Business Studies 23(4): 675-696.

Lu JW, Beamish PW. 2004. International diversification and firm performance: the s-curve hypothesis. Academy of Management Journal 47(4): 598-609.

Lu JW, Beamish PW. 2006. SME internationalization and performance: Growth vs. profitability. Journal of International Entrepreneurship 4(1): 27-48.

Luo Y, Peng MW. 1999. Learning to compete in a transition economy: experience, environment, and performance. Journal of International Business Studies 30: 269-296.

Luo Y, Shenkar O. 2011. Toward a perspective of cultural friction in international business. Journal of International Management 17: 1-14.

Luo Y, Tung RL.2007. International expansion of emerging market enterprises: A springboard perspective. Journal of International Business Studies 38(4): 481-498.

Mair, J., Marti, I. 2009. Entrepreneurship in and around institutional voids: A case study of Bangladesh. Journal of Business Ventures, 29: 419-43

Mathews JA. 2006. Dragon multinationals: New players in 21st century globalization. Asia Pacific Journal of Management 23(1): 5-27.

Meyer KE. 2006. Globalfocusing: from domestic conglomerates to global specialists. Journal of Management Studies 43(5): 1109-1144.

Meyer KE, Estrin S, Kumar-Bhaumik S, Peng MW. 2008. Institutions, resources and entry strategies in emerging economies. Strategic Management Journal 30(1): 61-80.

Nelson JM, Tilley C, Walker L. 1998. Transforming post-Communist political economies: Task force on economies in transition, National Research Council. Washington, DC: National Academy Press.

North, D. 1990. Institutions, institutional change and economic performance. New York: Cambridge University Press.

OUSTR. Free Trade Agreements. http://www.ustr.gov/trade-agreements/free-trade-agreements. (10 January 2012).

Peng MW. 2003. Institutional transitions and strategic choices. Academy of Management Review 28(2): 275-296. 
Peng MW, Lee S, Wang D. 2005. What determines the scope of the firm over time? A focus on institutional relatedness. Academy of Management Review 30(3): 622-633.

Prahalad CK, Bettis RA. 1986. The dominant logic - A new linkage between diversity and performance. Strategic Management Journal 7(6): 485-501.

Prahalad CK, Doz Y. 1987. The multinational mission: Balancing local demands and global vision. New York: The Free Press.

Qian G. 1997. Assessing product-market diversification of US firms. Management International Review 37(2):127-150.

Ramaswamy K, Kroeck KG, Renforth W. 1996. Measuring the degree of internationalization of a firm: A comment. Journal of International Business Studies 27(1): 167- 177.

Ronen S, Shenkar, O. 1985. Clustering Countries on Attitudinal Dimensions: A Review and Synthesis. The Academy of Management Review, 10(3): 435-454.

Rugman A, Verbeke A. 2004. A perspective on regional and global strategies of multinational enterprises. Journal of International Business Studies 35(1): 3-18.

Rugman A, Verbeke A. 2005. Towards a theory of regional multinationals: A transaction cost economics approach. Management International Review 45(1): 5-17.

Rugman A, Verbeke A. 2007. Liabilities of regional foreignness and the use of firm-level versus country-level data: a response to Dunning et al., (2007). Journal of International Business Studies 38(1): 200-205.

Rugman A, Verbeke A. 2008a. A New Perspective on the Regional and Global Strategies of Multinational Services Firms. Management International Review 48(4): 397-411.

Rugman A, Verbeke A. 2008b. The theory and practice of regional strategy: A response to Osegowitsch and Sammartino. Journal of International Business Studies 39: 326-332.

Rugman A, Verbeke A., Nguyen. 2011. Fifty years of International business theory and beyond. . Management International Review 51: 755-786.

Ruigrok W, Amann W, Wagner H. 2007. The internationalization-performance relationship at Swiss firms: A test of the S-shape and extreme degrees of internationalization. Management International Review 47(3): 349-368.

Shane S, Venkataraman S, Macmillan I. 1995. Cultural differences in innovation championing strategies. Journal of Management 21: 931-952. 
Shenkar O. 2001. Cultural distance revisited: Toward a more rigorous conceptualization and measurement of cultural differences. Journal of International Business Studies 32(3): 519-535.

Shenkar O, Luo Y, Yeheskel O. 2008. From "distance" to "friction": substituting metaphors and redirecting intercultural research. Academy of Management Review 33: 905-923.

Shleifer A, Vishny R. 1997. A survey of corporate governance. Journal of Finance, 52: 737-783.

Singer JD, Willett JB. 2003. Applied Longitudinal Data Analysis: Modeling Change and Event Occurrence. Oxford University Press, Inc: New York, NY.

Skaggs BC, Youndt M. 2004. Strategic positioning, human capital, and performance in service organizations: a customer interaction approach. Strategic Management Journal 25(1): 85-99.

StataCorp. 2005. Stata Statistical Software: Release 9.0 College station, TX: StataCorp LP.

State. Background Note: Brazil. http://www.state.gov/r/pa/ei/bgn/35640.htm. (13 January 2012).

Sullivan D. 1994. Measuring the Degree of Internationalization of a Firm. Journal of International Business Studies 25(2): 325-342.

Taggart, JH. 1997. An evaluation of the integration-responsiveness framework: MNC Manufacturing subsidiaries in the UK. Management International Review 37(4): 295-318.

Tallman S, Li J. 1996. Effects of international diversity and product diversity on the performance of multinational firms. Academy of Management Journal 39(1): 179-196.

Tan D, Meyer K. 2010. Business groups' outward FDI: A managerial resources perspective. Journal of International Management 16(2): 154-164

Thomas D, Eden L. 2004. What is the shape of the multinationality-performance relationship? Multinational Business Review 12(1): 89-110.

Thomas LG, D'Aveni RA. 2010. The rise of hypercompetition from 1950 to 2002: Evidence of increasing industry destabilization and temporary competitive advantage. Working paper 200411. Tuck School of Business at Darmouth, Hanover, NH.

Tihanyi L, Griffith DA, Russell CJ. 2005. The effect of cultural distance on entry mode choice, international diversification, and MNE performance: a meta-analysis. Journal of International Business Studies 36: 270-283.

UNCTAD (United Nations Conference on Trade and Development). 2006. World investment report. http://www.unctad.org/en/docs/wir2006_en.pdf. (20 April 2009). 
UNCTAD (United Nations Conference on Trade and Development). 2008. World investment report country fact sheets .http://www.unctad.org/sections/dite_dir/docs/wir08_fs_br_en.pdf. (15 October 2009).

UNCTAD (United Nations Conference on Trade and Development). 2010. World investment report: Investing in a low-Carbon economy.http://www.unctad.org/en/docs/wir2010_en.pdf. (20 December 2010)

USA Today. 2003. 39 million make Hispanics largest U.S. minority group. http://www.usatoday.com/news/nation/census/2003-06-18-Census_x.htm. (05 January 2012).

Vassolo RS, De Castro JO, Gomez-Mejia LR. 2011. Managing in Latin America: Common issues and research agenda. The Academy of Management Perspectives 25(4): 22-36.

Vermeulen F, Barkema H. 2002. Pace, Rhythm, and Scope: Process Dependence in Building a Profitable Multinational Corporation. Strategic Management Journal 23(7): 637-653.

Verbeke A, Li L, Goerzen A. 2009. Toward more effective research on the multinationalityperformance relationship. Management International Review 49(2): 149-162.

Wan WP, Hoskisson RE. 2003. Home country environments, corporate diversification strategies, and firm performance. Academy of Management Journal 46(1): 27-45.

Wells LT. 1983. Third world multinationals: The rise of foreign investment from developing countries. Cambridge, MA: The MIT Press.

Wiersema MF, Bowen HP. 2011. The relationship between international diversification and firm performance: why it remains a puzzle. Global Strategy Journal 1(1): 152-170.

Wiersema MF, Bantel KA. 1992. Top management team demography and corporate strategic change. Academy of Management Journal 35(1): 91-121.

Williamson, O. 1975. Markets and Hierarchies. New York: Free Press.

Williamson J. 2004. The strange history of the Washington consensus. Journal of Post Keynesian Economics, 27: 195-206.

Wooldridge, J. 2002. Econometric Analysis of Cross Section and Panel Data. MIT Press: Cambridge, MA.

WEF (World Economic Forum). 2006. The Latin America Competitiveness Review 2006: Paving the way for regional prosperity. http://www.weforum.org/pdf/Latin_America/Review.pdf. (15 January 2008). 
Yiu D, Bruton GD, Lu Y. 2005. Understanding business group performance in an emerging economy: Acquiring resources and capabilities in order to prosper. Journal of Management Studies 42 (1): 183-206.

Yiu D, Lu Y, Bruton GD, Hoskisson RE. 2007. Business groups: An integrated model to focus future research. Journal of Management Studies 44 (8): 1551-1579.

Zaheer S. 1995. Overcoming the liability of foreignness. Academy of Management Journal 38 (2):341-363.

Zaheer S, Mosakowski E. 1997. The dynamics of the liability of foreignness: A global study of survival in financial services. Strategic Management Journal 18(6): 439-464.

Zeithaml V, Parasuraman A, Berry LL. 1985. Problems and strategies in services marketing. Journal of Marketing 49(2):33-46. 


\section{VITA}

\section{ARMANDO BORDA}

September 22, 1972

1990-1994

2000-2001

2008-2009
Lima, Peru

B.A., Business Administration

Universidad de Lima

Lima, Peru

M.B.A.

Universidad ESAN

Lima, Peru

Doctoral Candidate

Florida International University

Miami Florida

\section{PUBLICATIONS AND PRESENTATIONS}

Borda, A., Newburry, W., Kundu, S. 2011. Firm internationalization, business group diversification and firm performance: The case of Latin American firms. Paper presented at Iberoamerican Academy of Management.

Newburry, W., Soleimani, A., Borda, A. 2011 (forthcoming). 'Reputations and Supportive Behavior of Spanish and U.S. Firms in Mexico'. In Niedrist, G. (Ed.), 'EU-Mexican, Legal, Commercial and Business Relations'.

Newburry, W., Borda, A., Alvarado, M., Galli, J. 2011. Perceived carreer opportunities from globalization: globalization capabilities and attitudes towards women in Peru and Brazil. Paper presented at Iberoamerican Academy of Management.

Borda, A., Newburry, W. 2011. Emerging multinationals and the interaction between learning capabilities and country specific factors: the impact on the number, location and survival of subsidiaries. Paper presented at the Academy of Management annual conference.

Borda, A., Newburry, W. 2011. Multinationality and Performance in Latin American firms: Assessing the Impact of Group Membership and Diversification. Paper presented at the SMS Rio special conference.

Borda, A., Newburry, W. 2010. Diversification and performance in Latin American firms: assessing the impact of product and geographic diversification. Paper presented at the annual meeting of the AIB. 
Borda, A., Newburry, W. 2010 The impact of technological intangible assets in location decisions of emerging multinationals. Paper presented at the annual meeting of the AIB.

Borda, A. 2009. The role of subsidiaries in emerging multinationals: The case of Multilatinas. Paper presented at the annual meeting of the AIB.

Borda, A. 2008. The relationship between internationalization and performance (M-P) in the context of Latin American Firms. Paper presented at the annual meeting of the Academy of International Business (AIB).

Wakabayashi, J., Borda A. 2008. 'Servicios veterinarios: donde vacunar, sector avícola, mascotas o vacuno'. Online Journal of International Case Analysis, 1(1): 23-38.

Serida, J., Borda, A., Uehara, L., Nakamatsu, K., Alzamora, J. 2007. 'Global Entrepreneurship Monitor: Peru 2007’. Lima: Universidad Esan

Wakabayashi, J., Borda A. 2006. Servicios veterinarios: donde vacunar, sector avícola, mascotas o vacuno. Paper presented at the annual meeting of CLADEA.

Serida, J., Borda, A. and Nakamatsu, K. 2006. 'Global Entrepreneurship Monitor: Peru 2006'. Lima: Universidad Esan.

Wakabayashi, J., Borda A. 2004. Case study Deltron. Paper presented at the annual meeting of Consejo Latinoamericano de Escuelas de Administración (CLADEA). 